Prepared in cooperation with the Legislative-Citizen Commission on Minnesota Resources

\title{
Potential Groundwater Recharge Rates for Two Subsurface-Drained Agricultural Fields, Southeastern Minnesota, 2016-18
}

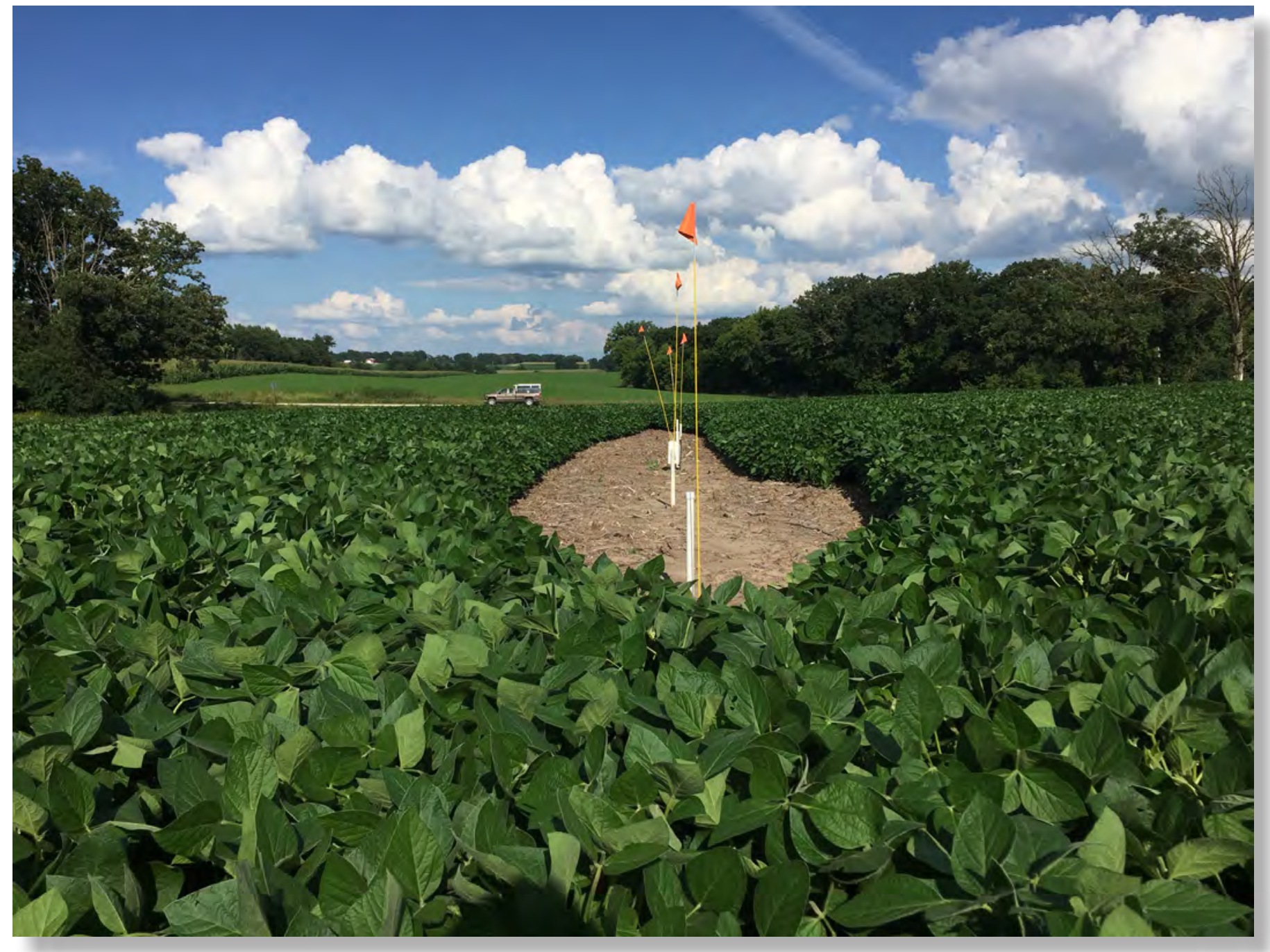

Scientific Investigations Report 2020-5006 
Cover. Photograph showing a piezometer nest, included as part of this study, near Ostrander, Minnesota. Photograph taken July 2017 by Andrew Berg, U.S. Geological Survey.

Back cover. Photograph showing the south drained site, looking towards the northwest across the field. Photograph taken June 2017 by Andrew Berg, U.S. Geological Survey. 


\section{Potential Groundwater Recharge Rates for Two Subsurface-Drained Agricultural Fields, Southeastern Minnesota, 2016-18}

By Erik A. Smith and Andrew M. Berg

Prepared in cooperation with the Legislative-Citizen Commission on Minnesota

Resources

Scientific Investigations Report 2020-5006 


\title{
U.S. Department of the Interior \\ DAVID BERNHARDT, Secretary
}

\author{
U.S. Geological Survey \\ James F. Reilly II, Director
}

U.S. Geological Survey, Reston, Virginia: 2020

For more information on the USGS - the Federal source for science about the Earth, its natural and living resources, natural hazards, and the environment-visit https://www.usgs.gov or call 1-888-ASK-USGS.

For an overview of USGS information products, including maps, imagery, and publications, visit https://store.usgs.gov/.

Any use of trade, firm, or product names is for descriptive purposes only and does not imply endorsement by the U.S. Government.

Although this information product, for the most part, is in the public domain, it also may contain copyrighted materials as noted in the text. Permission to reproduce copyrighted items must be secured from the copyright owner.

Suggested citation:

Smith, E.A., and Berg, A.M., 2020, Potential groundwater recharge rates for two subsurface-drained agricultural fields, southeastern Minnesota, 2016-18: U.S. Geological Survey Scientific Investigations Report 2020-5006, 57 p., https://doi.org/10.3133/sir20205006.

Associated data for this publication:

Smith, E.A., 2020a, DRAINMOD simulations for two agricultural drainage sites in western Fillmore County, southeastern Minnesota: U.S. Geological Survey data release, https://doi.org/10.5066/P987N30U.

Smith, E.A., 2020b, Soil-Water Balance model datasets used to estimate recharge for southeastern Minnesota, 2014-2018: U.S. Geological Survey data release, https://doi.org/10.5066/P90N4AWG.

Smith, E.A., 2020c, Potential groundwater recharge estimates based on a groundwater rise analysis technique for two agricultural sites in southeastern Minnesota, 2016-2018: U.S. Geological Survey data release, https://doi. org/10.5066/P94LMOPP.

U.S. Geological Survey, 2019, USGS groundwater data for Minnesota in USGS water data for the Nation: U.S. Geological Survey National Water Information System database, accessed October 10, 2019, at https://doi. org/10.5066/F7P55KJN.

ISSN 2328-0328 (online) 


\section{Acknowledgments}

Funding for this study was provided by a grant from the Environmental and Natural Resource Trust Fund of Minnesota (Legislative-Citizen Commission on Minnesota Resources) and from U.S. Geological Survey Cooperative Matching Funds.

Donald Anderson and James Nelson, both of Ostrander, Minnesota, are greatly acknowledged for their willingness and cooperation to provide their agricultural fields for this study.

Assistance for securing field-scale monitoring plots included personnel from several State agencies, including the Minnesota Department of Natural Resources, Minnesota Pollution Control Agency, and Minnesota Department of Agriculture. Additionally, Beau Kennedy from the Goodhue Soil and Water Conservation District and Bev Nordby from the Mower Soil and Water Conservation District were also helpful in early study discussions. Brent Mason, Minnesota Department of Natural Resources and former U.S. Geological Survey employee, is also acknowledged for his assistance with installing and removing all piezometers. The authors also thank Jason Roth of the Natural Resources Conservation Service for a thorough DRAINMOD model review.

Stephen Kalkhoff and Jared Trost of the U.S. Geological Survey are acknowledged for colleague reviews of the report. Megan Haserodt and Timothy Cowdery of the U.S. Geological Survey assisted with model reviews of the Soil-Water-Balance and the RISE Water-Table Fluctuation models, respectively. 



\section{Contents}

Acknowledgments ……...................................................................................................................

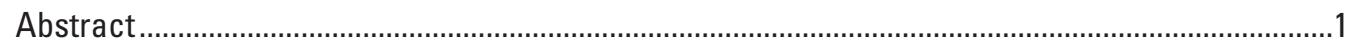

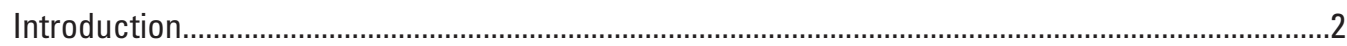

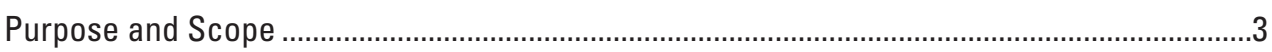

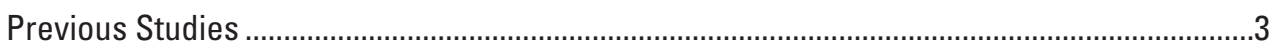

Study Area and Hydrologic Setting .............................................................................

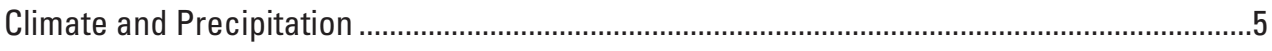

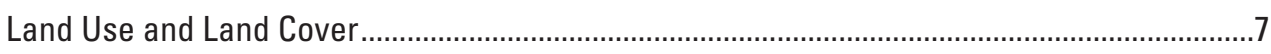

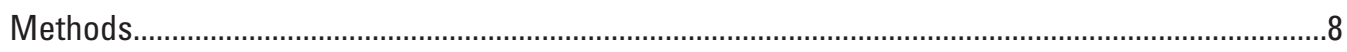

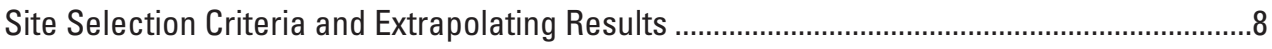

Drained and Undrained Monitoring Plots ...............................................................................11

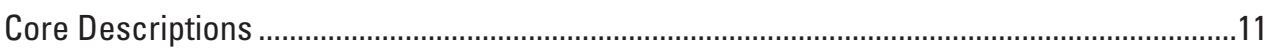

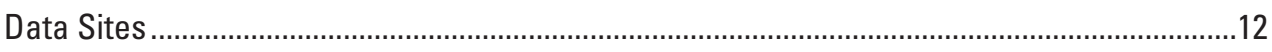

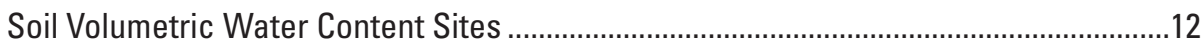

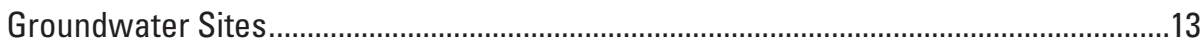

Meteorological Sites and Evapotranspiration Calculations ...........................................14

Subsurface Drainage Flow Monitoring Sites ..................................................................15

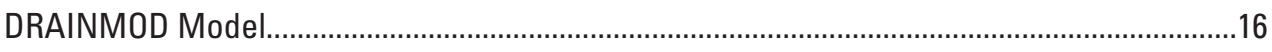

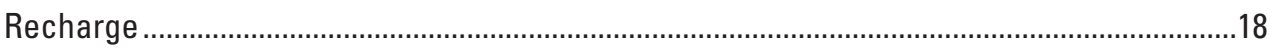

RISE Water-Table Fluctuation Method .....................................................................18

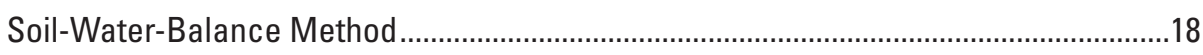

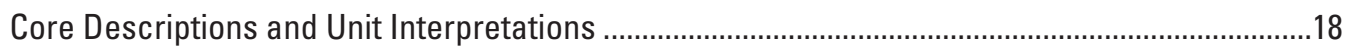

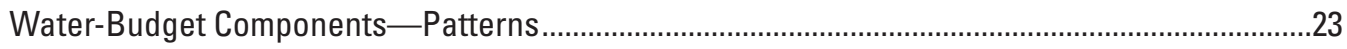

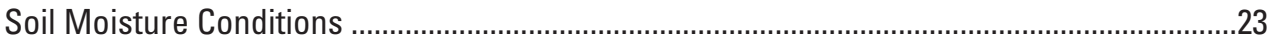

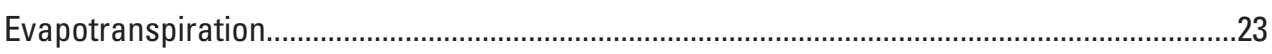

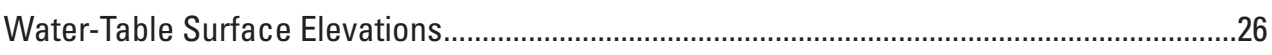

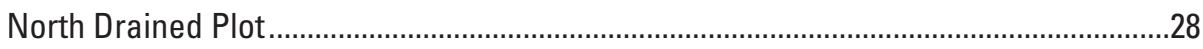

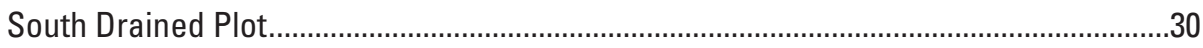

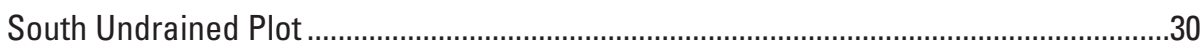

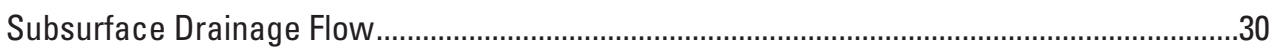

Potential Groundwater Recharge Rates ....................................................................................3

Potential Recharge - RISE Water-Table Fluctuation and Soil-Water-Balance Estimates.....33

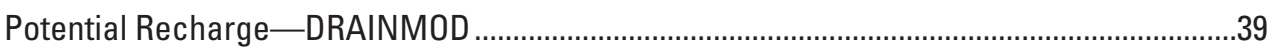

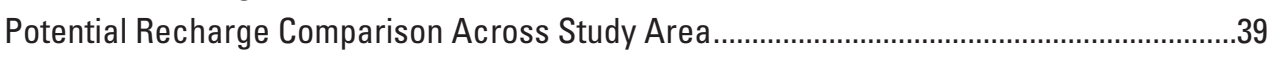

Limitations and Assumptions .............................................................................................4

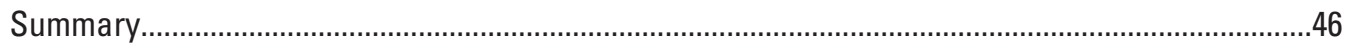

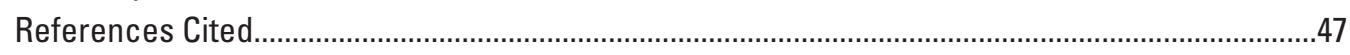

Appendix 1. Instantaneous Subsurface Drainage Flow Rates, Every 15 Minutes, 2017-18 .........53

Appendix 2. Daily Total Subsurface Drainage, 2017-18 ..............................................................54 


\section{Figures}

1. Map showing location of the three field-scale monitoring plots in Fillmore County, Minnesota.

2. Map showing major north drained site locations, including the piezometer nests, soil moisture probes, meteorological station, and subsurface drainage site ........9

3. Map showing major south drained and undrained plot locations, including the piezometer nests, soil moisture probes, meteorological station, and subsurface drainage site.

4. Map showing land cover in the immediate study area around the two farmsteads, at a 30-meter resolution, from the 2017 Cropland Data Layers.

5. Select photographs from the subsurface drain excavation at the south drained plot, Fillmore County, Minnesota, November 2016

6. A hypothetical configuration of one of the two drained field plots, including the meteorological station, a piezometer transect for continuous water-level measurements between two parallel subsurface drains, perimeter piezometers for background water-level measurements, soil moisture probes, and subsurface drainage flow

7. Select photographs from the subsurface drain flow monitoring installation at the north drained plot, Fillmore County, Minnesota, November 2016.

8. Graphs showing volumetric water content for the north drained transects for October 2016 through September 2018.

9. Graphs showing volumetric water content for the south drained transects and the south undrained transect from April 2017 through September 2018.

10. Graphs showing volumetric water content for the north drained transects, from June 9 through June 23, 2018

11. Graph showing potential evapotranspiration for both farmsteads, calculated from the meteorological data at North Site Weather Station and South Site Weather Station, from June 1 to October 1, 2018.

12. Graphs showing water-table surface elevations for the three north drained transects from December 2016 through September 2018.

13. Graphs showing water-table surface elevations for the two drained transects and the one undrained transect at the south farmstead from March 2017 through September 2018.

14. Graph showing total subsurface drainage flow, in inches per day, for the North Site Agri Drain and the South Site Agri Drain from April 1 to July 15, 2018

15. Graphs showing simulated and observed water-table surface elevation for two of the nine DRAINMOD model scenarios from March 1, 2017, to October 1, 2018: STR2-2 and NPR-4 


\section{Tables}

1. Continuous and discrete piezometer network, including piezometer identification, transect array, site number, latitude/longitude, land surface altitude, screen intervals, and well depths...

2. Non-piezometer data collection across the three monitoring plots, including soil moisture, subsurface drainage flow, and meteorological data

3. Distribution of land cover in the study area, based on the 2017 Cropland Data Layers

4. Grain size distributions for all seven cores across the three monitoring plots. Also included is the depth range, textural analysis, U.S. Department of Agriculture texture, and the interpreted deposit type

5. Summary statistics, including minimum, maximum, mean, and median volumetric water content for the north drained plot transects, south drained plot transects, and the south undrained plot

6. Total subsurface drainage flow and precipitation, by month, from April 2017 through October 2018.

7. Calculated groundwater recharge rates for water year 2017 based on the RISE program.

8. Calculated groundwater recharge rates for water year 2018 based on the RISE program.

9. Summary statistics, including minimum, maximum, mean, and median potential recharge as calculated by the RISE program for water years 2017 and 2018, grouped by different categories of piezometer records.

10. Model parameters used for the nine DRAINMOD model scenarios discussed in this report, summarized by individual DRAINMOD model scenario

11. Potential recharge rate and two calibration statistics for the nine DRAINMOD model scenarios completed across the study area. .. .44

12. Annual potential recharge rates based on the DRAINMOD model and RISE Water-Table Fluctuation method, grouped by water year. 


\section{Conversion Factors}

U.S. customary units to International System of Units

\begin{tabular}{|c|c|c|}
\hline Multiply & By & To obtain \\
\hline \multicolumn{3}{|c|}{ Length } \\
\hline inch (in.) & 25.4 & millimeter $(\mathrm{mm})$ \\
\hline foot $(\mathrm{ft})$ & 0.3048 & meter $(\mathrm{m})$ \\
\hline mile (mi) & 1.609 & kilometer (km) \\
\hline \multicolumn{3}{|c|}{ Area } \\
\hline square foot $\left(\mathrm{ft}^{2}\right)$ & 0.09290 & square meter $\left(\mathrm{m}^{2}\right)$ \\
\hline acre & $4,046.86$ & square meter $\left(\mathrm{m}^{3}\right)$ \\
\hline square mile $\left(\mathrm{mi}^{2}\right)$ & 2.590 & square kilometer $\left(\mathrm{km}^{2}\right)$ \\
\hline \multicolumn{3}{|c|}{ Volume } \\
\hline cubic foot $\left(\mathrm{ft}^{3}\right)$ & 0.02832 & cubic meter $\left(\mathrm{m}^{3}\right)$ \\
\hline \multicolumn{3}{|c|}{ Flow rate } \\
\hline foot per second (ft/s) & 0.3048 & meter per second $(\mathrm{m} / \mathrm{s})$ \\
\hline inch per day (in/day) & 2.54 & centimeter per day (cm/day) \\
\hline cubic foot per second $\left(\mathrm{ft}^{3} / \mathrm{s}\right)$ & 0.02832 & cubic meter per second $\left(\mathrm{m}^{3} / \mathrm{s}\right)$ \\
\hline \multicolumn{3}{|c|}{ Pressure } \\
\hline atmosphere, standard (atm) & 101.3 & kilopascal $(\mathrm{kPa})$ \\
\hline \multicolumn{3}{|c|}{ Energy } \\
\hline kilowatt hour (kWh) & $3,600,000$ & joule $(\mathrm{J})$ \\
\hline \multicolumn{3}{|c|}{ Hydraulic conductivity } \\
\hline foot per day (ft/d) & 0.3048 & meter per day $(\mathrm{m} / \mathrm{d})$ \\
\hline
\end{tabular}

Temperature in degrees Celsius $\left({ }^{\circ} \mathrm{C}\right)$ may be converted to degrees Fahrenheit $\left({ }^{\circ} \mathrm{F}\right)$ as follows:

${ }^{\circ} \mathrm{F}=\left(1.8 \times{ }^{\circ} \mathrm{C}\right)+32$.

Temperature in degrees Fahrenheit $\left({ }^{\circ} \mathrm{F}\right)$ may be converted to degrees Celsius $\left({ }^{\circ} \mathrm{C}\right)$ as follows:

$$
{ }^{\circ} \mathrm{C}=\left({ }^{\circ} \mathrm{F}-32\right) / 1.8 \text {. }
$$

\section{Datum}

Vertical coordinate information is referenced to the North American Vertical Datum of 1988 (NAVD 88).

Horizontal coordinate information is referenced to the North American Datum of 1983 (NAD 83). Elevation, as used in this report, refers to distance above the vertical datum.

\section{Supplemental Information}

A water year is the 12-month period October 1, for any given year through September 30, of the following year. 


\section{Abbreviations}

$\begin{array}{ll}\text { AV } & \text { area velocity } \\ \text { DEM } & \text { digital elevation model } \\ \text { ET } & \text { evapotranspiration } \\ \text { ET }_{0} & \text { potential evapotranspiration } \\ \text { MAE } & \text { mean absolute error } \\ \text { MDA } & \text { Minnesota Department of Agriculture } \\ \text { MGS } & \text { Minnesota Geological Survey } \\ \text { NLCD } & \text { National Land Cover Database } \\ \text { NSAD } & \text { North Site Agri Drain } \\ \text { NSI } & \text { Nash-Sutcliffe index of efficiency } \\ \text { NWIS } & \text { National Water Information System } \\ \text { PVC } & \text { polyvinyl chloride } \\ R 2 & \text { coefficient of determination } \\ \text { SSAD } & \text { South Site Agri Drain } \\ \text { SSURGO } & \text { Soil Survey Geographic } \\ \text { SSWS } & \text { South Site Weather Station } \\ \text { SWB } & \text { Soil-Water-Balance } \\ \text { USGS } & \text { U.S. Geological Survey } \\ \text { VWC } & \text { volumetric water content } \\ \text { WTF } & \text { Water-Table Fluctuation }\end{array}$





\title{
Potential Groundwater Recharge Rates for Two Subsurface-Drained Agricultural Fields, Southeastern Minnesota, 2016-18
}

\author{
By Erik A. Smith and Andrew M. Berg
}

\section{Abstract}

Subsurface drainage is used to efficiently drain saturated soils to support productive agriculture in poorly drained terrains. Although subsurface drainage alters the water balance for agricultural fields, its effect on groundwater resources and groundwater recharge is poorly understood. In Minnesota, subsurface drainage has begun to increase in southeastern Minnesota, even though this part of the State is underlain by permeable karstic bedrock aquifers with only a thin layer of glacial sediments separating these aquifers from land surface.

To gain a better understanding of groundwater recharge effects from subsurface drainage, the U.S. Geological Survey (USGS), in cooperation with the Legislative-Citizen Commission on Minnesota Resources, led a 2-year hydrologic study to investigate this connection for two agricultural fields in southeastern Minnesota with subsurface drainage. A total of three monitoring plots were used between the two agricultural fields: two monitoring plots that included an actively drained area with peripheral, undrained areas, and a third monitoring plot without any subsurface drainage. Multiple piezometer transects were set up across the three monitoring plots to characterize the unsaturated zone and shallow watertable flow using pressure transducers and soil moisture probes. From these piezometers, groundwater recharge rates were derived using two different methods: the RISE Water-Table Fluctuation (WTF) method and the DRAINMOD model. In addition to these two methods, the USGS Soil-Water-Balance (SWB) model was used to estimate potential recharge rates for three different monitoring plots.

In addition to deriving groundwater recharge rates, the hydrologic budget was analyzed to interpret the water-table surface elevation and soil volumetric water content time series. At one of the two drained plots, the transects exhibited varying water-table surface elevation patterns. Frequent backflow from the adjacent ditch caused subsurface drainage flow to slow down or stop drainage through the main collector drain and cause pipe pressurization, so the closest transect appeared to be mostly controlled by the drain pressurization, whereas the farthest transect was more efficiently drained. Both of the drained monitoring plots had an elevation gradient parallel to the pattern tiles, sloping downward towards the collector drain that aggregated the parallel lines into a single drain. Because the transects were set at different gradients in the field, some of the water-table surface elevation differences were also attributed to lateral flow towards the lowest parts of the field.

Three methods were used to derive potential groundwater recharge rates: the RISE WTF method, the USGS SWB model, and DRAINMOD-derived deep seepage rates. Potential groundwater recharge rates, using the RISE WTF method, across all piezometers were 1.55 and 1.94 inches per year, respectively, for water years 2017 and 2018. More differentiation of potential recharge rates between different piezometer types occurred for water year 2018. Although the difference was slightly more than 1 inch between the drained and nondrained piezometers for water year 2018, this difference was statistically significant based on a t-test with a $p$-value of $0.036(\alpha=0.05)$. When looking at recharge based on distance from the drain, the subsurface drain did not affect potential recharge, although other factors such as variability in screen depths, well construction, and specific yield variability cannot be eliminated. The SWB model was also used to estimate potential recharge rates for water years 2017-18, with rates between 2.44 and 5.92 inches per year for the two drained sites, generally higher than the RISE WTF estimates. DRAINMOD-derived potential recharge rates were generally the highest of the three methods, with potential recharge rates varying from 2.07 to 9.49 inches per year.

Overall, there was a lack of agreement between the three methods. These results were not remarkable, considering the fundamental differences in the methodology for each method. However, all methods did show a fundamental difference between piezometers within the drained area and piezometers outside the drained area, including the third undrained monitoring plot. The drained areas show a lower overall potential groundwater recharge compared to the nondrained areas for all three estimates. The difference for the 2018 recharge estimates was slightly higher than 1 inch for the RISE WTF method, the difference was almost double for the nine sites for the DRAINMOD model, and the difference between the drain and undrained plots was even more significant for the SWB model. 


\section{Introduction}

In the recently glaciated areas of the upper Midwestern United States (eastern North Dakota, northeastern South Dakota, western and southern Minnesota, and north-central Iowa), the abundant use of artificial surface and subsurface drainage networks has substantially altered the hydrological conditions from its pre-developed, post-glacial state (Beauchamp, 1987; Zucker and Brown, 1998). Because the modern landscape of this region is largely a remnant of the last glaciation (Wright, 1972), it stands to reason the underlying hydrology is also affected by this glaciation and the till and outwash sediments left behind. Much of this region is low relief, containing many topographic depressions (prairie potholes) underlain by poorly drained soils (Roth and Capel, 2012).

Before this poorly drained landscape could be effectively cultivated for productive agriculture, a land transformation had to take place that began with the construction of extensive networks of surface drainage ditches (Wilson, 2016; Capel and others, 2018). In Minnesota, some of the earliest efforts began in the Red River Valley of western Minnesota with the formation of the Red River Drainage Commission in 1893 (Hanson, 1987; Smith and others, 2018a). Similar types of drainage districts sprang up in other parts of Minnesota during this period and continued into the early 20 th century.

Along with the construction of surface ditch networks, drainage practices eventually evolved towards the inclusion of artificial subsurface drainage networks (Blann and others, 2009; Capel and others, 2018). Artificial subsurface drainage is the practice of installing networks of perforated conduit below the land surface to drain the upper soil horizons of excess moisture. Subsurface drainage networks include single field, topographically located drains to patterned drain networks, spanning from a single field to multifield networks. The subsurface drains typically discharge into an adjacent stream or ditch, or connect to a larger publicly maintained subsurface drain network that carries the water to the nearest stream. Early on, subsurface drainage consisted of clay and concrete tile laid out by hand in a narrow, subsequently backfilled trench, but eventually the installation practice evolved towards the mechanical installation of perforated polyethylene plastic (Reeve and others, 1981). The installation of subsurface drainage networks continues through present day (2019) in Minnesota.

Subsurface drainage has become an essential component of Minnesota agriculture and other parts of the upper Midwest, making row-crop agriculture possible in areas that would likely suffer from lower yields or would not be economically viable (Fausey and others, 1987; Zucker and Brown, 1998). More than 25 percent of the croplands of the United States require improved drainage (Green and others, 2006). Where agricultural drainage has been installed in Minnesota, its primary role is to generally lower the water table and effectively drain ponded surface water. With proper drainage, crop production can be better managed through the prevention of water logging that can impair root proliferation, function, and metabolism because of saturated soil conditions (Fausey and others, 1987; Kanwar and others, 1998). Subsurface drainage also improves soil health by permitting biological processes that require the presence of oxygen (Moebius-Clune and others, 2017). Subsurface drainage also dries out the fields to allow for timely farm operations such as tiling, planting, and weed management (Beauchamp, 1987).

Agricultural drainage has also been connected to several environmental effects on water quality and water quantity (Blann and others, 2009). The environmental effects on surface water quality in particular are well-documented (for example, Dinnes and others, 2002; Kladivko and others, 2004; Richards and others, 2008; Rozemeijer and others, 2010). The Gulf of Mexico hypoxia zone, caused mainly by excessive nitrogen export through the Mississippi/Atchafalaya River Basin, has been connected back to agricultural basins with a high percentage of agricultural drainage (Goolsby and Battaglin, 2001; Randall and Mulla, 2001). Artificial drainage networks have also been correlated to watersheds that exhibited seasonal and annual water yield increases of greater than 50 percent since 1940 (Schottler and others, 2013).

The connection of agricultural subsurface drainage to changes in groundwater quantity, and the rate of replenishment through groundwater recharge, has not been well-established. Currently (2019), few studies have been carried out to document the shifts in the water balance caused by subsurface drainage (Schuh, 2008). By design, subsurface drainage expedites the movement of water from fields to nearby surface water bodies.

In Minnesota, drainage has historically been implemented in the south-central and western portions of the State, which are regions underlain primarily by thick impermeable glacial sediments (Hobbs and Goebel, 1982). Because of the impermeable nature of these glacial sediments, it has often been assumed that the natural, pre-drained rate of groundwater recharge to aquifers below these glacial sediments was so minimal that the net effect of the installation of subsurface drainage networks had a negligible effect on recharge (Schuh, 2008). Recently, though, due to shifts in climatic and economic factors, installation of subsurface drainage networks has begun to increase in southeastern Minnesota (Smith and others, 2018a). Unlike historically drained regions of the State, much of southeast Minnesota is underlain by thin glacial sediments, often less than 25 feet thick, layered over permeable karstic bedrock aquifers (Runkel and others, 2003). Given consideration of the decreased thickness of the glacial sediments covering these bedrock aquifers in southeast Minnesota, the prevailing assumption that subsurface drainage has a minimal effect on groundwater recharge deserves further consideration.

Before assumptions can be made about subsurface drainage effects on groundwater recharge, more studies need to be carried out. Previously (Fisher and Healy, 2008), water budgets of agricultural fields were one possible method for determining subsurface drainage effects on groundwater recharge. 
For a full agricultural field water budget with subsurface drainage, typical of southeastern Minnesota, all the inputs, outputs, and rates of change in the area of interest would need to be fully examined. In this case, a comprehensive water budget would require a full quantification of the changes in water storage for the shallow soils above the restricting layer to the aquifer below, including evapotranspiration (ET), surface runoff, the amount of water drained, and the deeper infiltration as groundwater recharge. However, even with accurate measurements of most of these fluxes, the residual groundwater recharge can be difficult to ascertain (Healy and others, 2007; Schuh, 2008; Smith and Westenbroek, 2015).

In an effort to gain a better understanding of groundwater recharge effects from agricultural drainage, the U.S. Geological Survey (USGS), in cooperation with the Legislative-Citizen Commission on Minnesota Resources, led a 2-year hydrologic investigation of two separate field sites in southeastern Minnesota. The study objective was to understand the effect that agricultural subsurface drainage might have on water infiltration below the root zone and on the overall potential groundwater recharge rates. Through field data collection, analysis, and numerical modeling, this study considered whether subsurface drainage had an appreciable effect on groundwater recharge rates for two agricultural field sites. These field sites included two drained plots and one undrained plot, with comparisons made between the three different plots. The overall study objective was to measure various water-budget components to isolate groundwater recharge rates underneath agricultural fields with and without subsurface drainage. These groundwater recharge rates would help inform the knowledge gap on how much recharge to the underlying bedrock is affected by agricultural drainage.

\section{Purpose and Scope}

The purpose of this report is to describe potential groundwater recharge rates for two subsurface-drained agricultural fields in southeastern Minnesota, 2016-18. This report also describes the establishment of field-scale monitoring plots in the two separate agricultural fields with active subsurface drains. All monitored plots had various water-budget components continuously monitored for 2 years. Subsurface drain flow was continuously monitored with varying success from the two plots with active subsurface drainage. For both drained plots, the subsurface drains were all perforated polyethylene plastic, often colloquially referred to as tile drains. Additionally, each monitoring plot had extensive piezometer networks to characterize shallow water-table flow and soil moisture probes for unsaturated zone characterization. In total, the two agricultural fields each had a field-scale monitoring plot with subsurface drains, with a third monitoring plot established within an undrained portion of one of the two fields. In addition to the continuous monitoring, numerical modeling was used to quantify potential groundwater recharge rates across the monitoring plots.

\section{Previous Studies}

Previous hydrogeologic investigations have described the karst terrain of southeastern Minnesota and the karst aquifers that underlie a high proportion of southeastern Minnesota. Runkel and others (2003) completed a comprehensive assessment of the Paleozoic bedrock hydrogeology for southeastern Minnesota. Other studies have highlighted the heterogeneity of hydraulic properties for these karst aquifers (Tipping and others, 2006), the complexity of flow patterns from the land surface to the aquifers (Green and others, 2012), and the susceptibility of these aquifers to pollution (St. Ores and others, 1982). A vast number of other publications have also focused on the region (for example, Williams and Vondracek, 2010; Groten and Alexander, 2013; Keeler and Polasky, 2014), given the distinction that the region's aquifers bear approximately 75 percent of all groundwater in Minnesota (St. Ores and others, 1982).

Groundwater recharge in southeastern Minnesota has been estimated in several studies. Delin (1991) delineated recharge rates as part of a groundwater-flow study for the region surrounding Rochester, Minnesota, approximately 30 miles from the study area. Lindgren (2001) also focused on groundwater flow and defined recharge rates surrounding Rochester, Minn. Statewide, several groundwater recharge estimates have been completed in the past 15 years. Lorenz and Delin (2007) estimated the mean annual recharge from 1971 to 2000, Smith and Westenbroek (2015) estimated the mean annual recharge from 1996 to 2010, and Trost and others (2018) estimated the mean annual recharge from 1980 to 2011 for the entire glacial aquifer system east of the Rocky Mountains.

Potential groundwater recharge studies for southeastern Minnesota in relation to subsurface drainage do not currently exist. In fact, possible agricultural drainage effects on groundwater recharge have been rarely studied (Smith and others, 2018a). To date, one of the best known studies on this topic was carried out in eastern North Dakota to assess the potential effects of subsurface drainage on water appropriation (Schuh, 2008, 2018). For eastern North Dakota, Schuh (2008) concluded that subsurface drainage might change the local groundwater recharge regime, but these cases would be rare. The study elaborated that subsurface-drained water is generally removed from an upper zone of active storage that is not considered long-term storage. However, the study also indicated the recharge processes to confined aquifers with small hydraulic gradients can be highly sensitive to small water-table changes, such as shifts in water tables caused by subsurface drainage.

Rather than direct studies of groundwater recharge, partial or complete water budgets in drained systems are another source for understanding subsurface drainage effects on groundwater recharge. Roth and Capel (2012) studied the water balance of a topographic depression (also termed a "prairie pothole") and determined that the perched water table was the groundwater source to the pothole when soils 
were saturated, whereas the water in the pothole infiltrated to the subsurface drain when soils were drier. DRAINMOD was used in the Red River Basin (northwest Minnesota) for several different soil types and it was determined that deep seepage to groundwater accounted for a very small percentage, approximately 1 to 3 percent, of the overall water budget (Jin and others, 2004). Fisher and Healy (2008) determined that groundwater recharge was enhanced by subsurface drainage for an Indiana site, as the subsurface drains enhanced recharge by reducing surface runoff and inducing water infiltration.

However, agricultural water budgets can be difficult to accurately quantify, largely due to substantial variations in ET rates. Yang and others (2017) determined that subsurface drainage slightly decreases ET overall on an annual basis, with elevated ET during peak growing season on row-cropped fields, but these fields had lower ET during early spring, fall, and other fallow periods. However, ET rates for corn and soybean fields in southeastern North Dakota were determined to be slightly higher in subsurface-drained fields (Rijal and others, 2012) for a 2-year period, and Khand and others (2017) found no statistically significant difference in daily ET between drained and undrained fields. In all three of these examples, the studies explore the interplay between ET and subsurface drainage, and do not explore the effects on deep seepage or groundwater recharge.

\section{Study Area and Hydrologic Setting}

All three monitoring plots for this study were in Fillmore County, Minn., in southeast Minnesota (fig. 1). Two different farmsteads were used; one of the two drained plots, (the north drained plot) was located on one farmstead, whereas the other two monitoring plots (the south drained and south undrained plots) were on the other farmstead. Agreements were secured with both landowners to allow for access and the installation of all piezometers, soil moisture probes, meteorological stations, and the subsurface drain sites. These fields were selected due to their characteristics typical of the region, such as shallow depth to bedrock, soil types common for subsurface drainage, low slopes, and established subsurface drainage.

Fillmore County is on the western edge of southeastern Minnesota. Recently, this region of Minnesota has seen an increase in drainage (Smith and others, 2018a). Unfortunately, no corroborating documentation of subsurface drainage tiling magnitude has been found for this report aside from these interviews.

The north and south farmsteads discharge all subsurface drain flow from the extent of their properties either directly or indirectly (via a connected surface ditch) to Beaver Creek, a tributary to the Upper Iowa River (fig. 1; not shown). As typical for this part of the State, major modifications have been made to the natural hydrology of the area. At the north drained plot (fig. 2), a surface ditch is located adjacent to the property that drains into Beaver Creek approximately 1 mile downstream. The north drained plot contained various data collection sites, including piezometers collecting continuous water levels, soil moisture probes, a subsurface drainage flow monitoring station, and a meteorological station (tables 1 and 2). The total study area for the north drained plot was estimated at approximately 6.3 acres, based on the detection of eight 4-inch diameter parallel drains in the field running east to west, with a single 6-inch diameter collector drain running from north to south before heading southwest to the surface ditch. On the western boundary of the north drained plot, the flow from the adjacent surface ditch flows under the road through a narrow culvert less than 2 meters in width. Because this section of ditch receives extensive drainage from north of the monitoring plot, in combination with a potentially undersized culvert, ditch water flow was often slow or completely stagnant and therefore periodically backed up into the field. Additionally, because this led to the subsurface drains off of the field to also back up, the field's drainage capacity was occasionally exceeded. In these cases, surface runoff would flow directly off of the field towards the ditch or pond in the field.

The south drained and undrained plots also drained towards Beaver Creek but through a different Beaver Creek branch than the north drained plot (fig. 3). Similar to the north drained plot, the south drained and undrained plots contained piezometers collecting continuous water levels and soil moisture probes, with a subsurface drainage flow monitoring station and a meteorological station as part of the drained plot (tables 1 and 2). For the south drained plot, all subsurface drainage was linked to Beaver Creek through an approximately 600-700-foot section of subsurface drain that tied together several properties (not shown on fig. 3). The total study area for the south drained plot was estimated at approximately 7.4 acres, based on the detection of three 4-inch diameter parallel drains in the field running approximately north to south, with a single 6-inch diameter collector drain running from northwest to southeast before heading towards the road culvert. Close to the road culvert, the collector drain supposedly joined the larger subsurface drain that tied together several properties, although this was not physically confirmed. Surface runoff at the south drained plot tended to move towards the lower buffer areas shown in the middle of the south drained plot (fig. 3). For the third monitoring plot, the south undrained plot, no actual estimate of the study area was necessary because it was not underlain by subsurface drains, although for reference the approximate size of the delineated subfield was 2.7 acres.

Physiographically, both agricultural fields were within an area of southeastern Minnesota that was glaciated (Runkel and others, 2003). The glacial deposits in general range from less than 10 to more than 75 meters in thickness and mainly consist of till with interbedded sand and gravel lens. These deposits overlie bedrock aquifers that consist of Paleozoic sandstone and carbonate aquifers, interstratified by low permeability carbonates and shales (Mossler, 1995; Runkel and others, 2003). These thin till layers are the general location of subsurface drainage in southeastern Minnesota. 


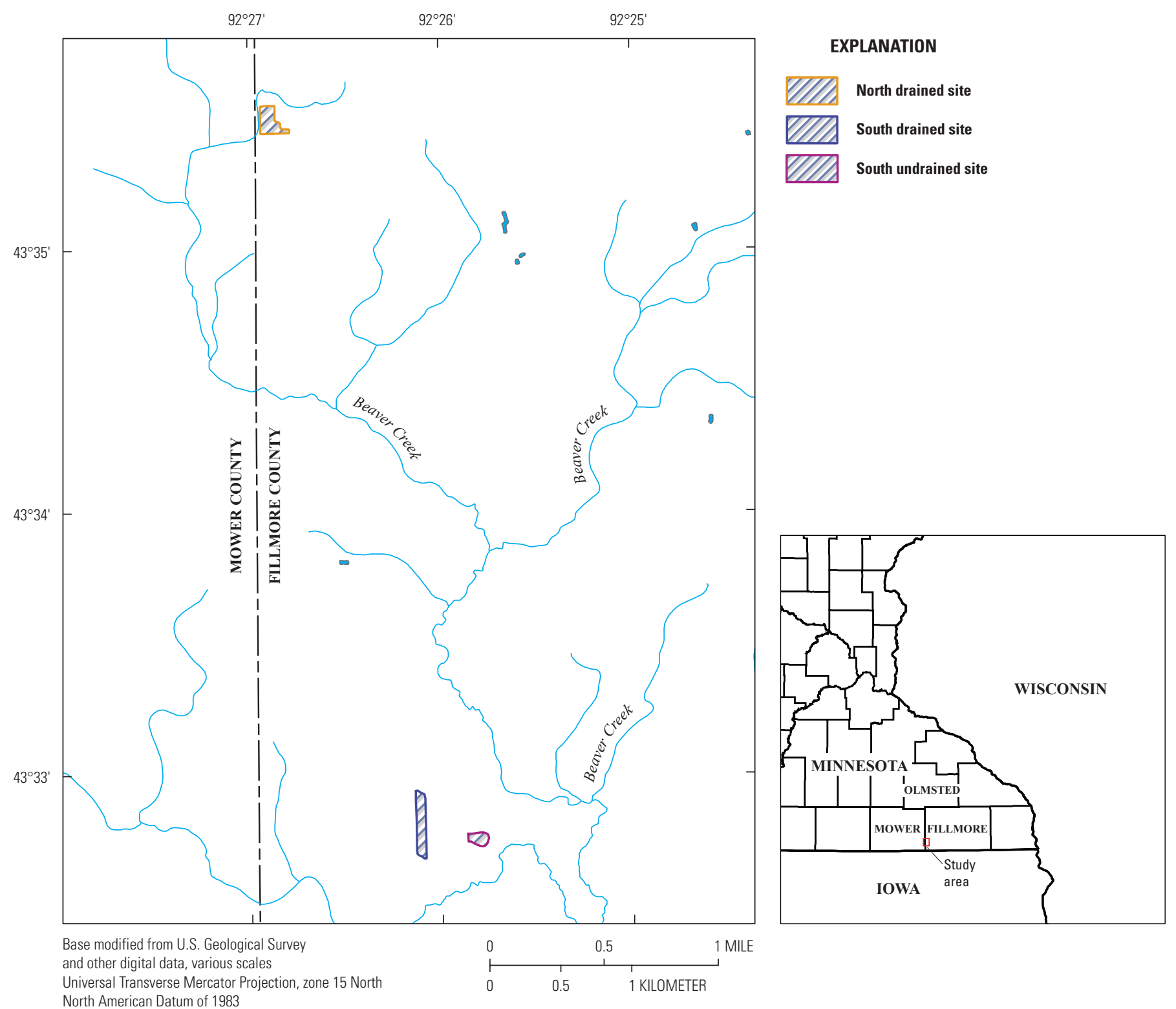

Figure 1. Location of the three field-scale monitoring plots (two drained plots, one undrained plot) in Fillmore County, Minnesota. Beaver Creek and some of the connecting surface ditches are also shown.

To obtain specific information for this study, seven complete cores were sent to the Minnesota Geological Survey (MGS) for full descriptions: four of the sediment cores were from the north drained plot, two from the south drained plot, and a single core from the south undrained plot. These cores confirmed that most of these fields were underlain by various till complexes, outwash deposits, and loess. The textures from the cores mostly clustered as loam, clay loam, and silty clays with a few notable exceptions. More details on the cores are available in the "Core Descriptions and Unit Interpretations" section. Soils for the three monitoring plots were developed under long-grass prairies on the glacial till deposits and are highly productive (Cowles and others, 1958). Major soils present at the plots, based on Natural Resources
Conservation Service SSURGO data, included Floyd silty clay loam, Clyde silty clay loam, Kasson silt loam, Kenyon silt loam, and Renova silt loam (Natural Resources Conservation Service, 2019).

\section{Climate and Precipitation}

The climate of the study area is humid continental, with warm, humid summers and cold winters with heavy snowfall. Climate data from the Rochester International Airport (not shown; National Climatic Data Center, 2019), about 24-28 miles north of the study area (north drained plot, 24 miles; south drained/undrained plots, 28 miles), had a long 
Table 1. Continuous and discrete piezometer network, including piezometer identification (short name), transect array (if applicable), site number, latitude/longitude, land surface altitude, screen intervals, and well depths.

[ID, identification; USGS, U.S. Geological Survey; --, nontransect]

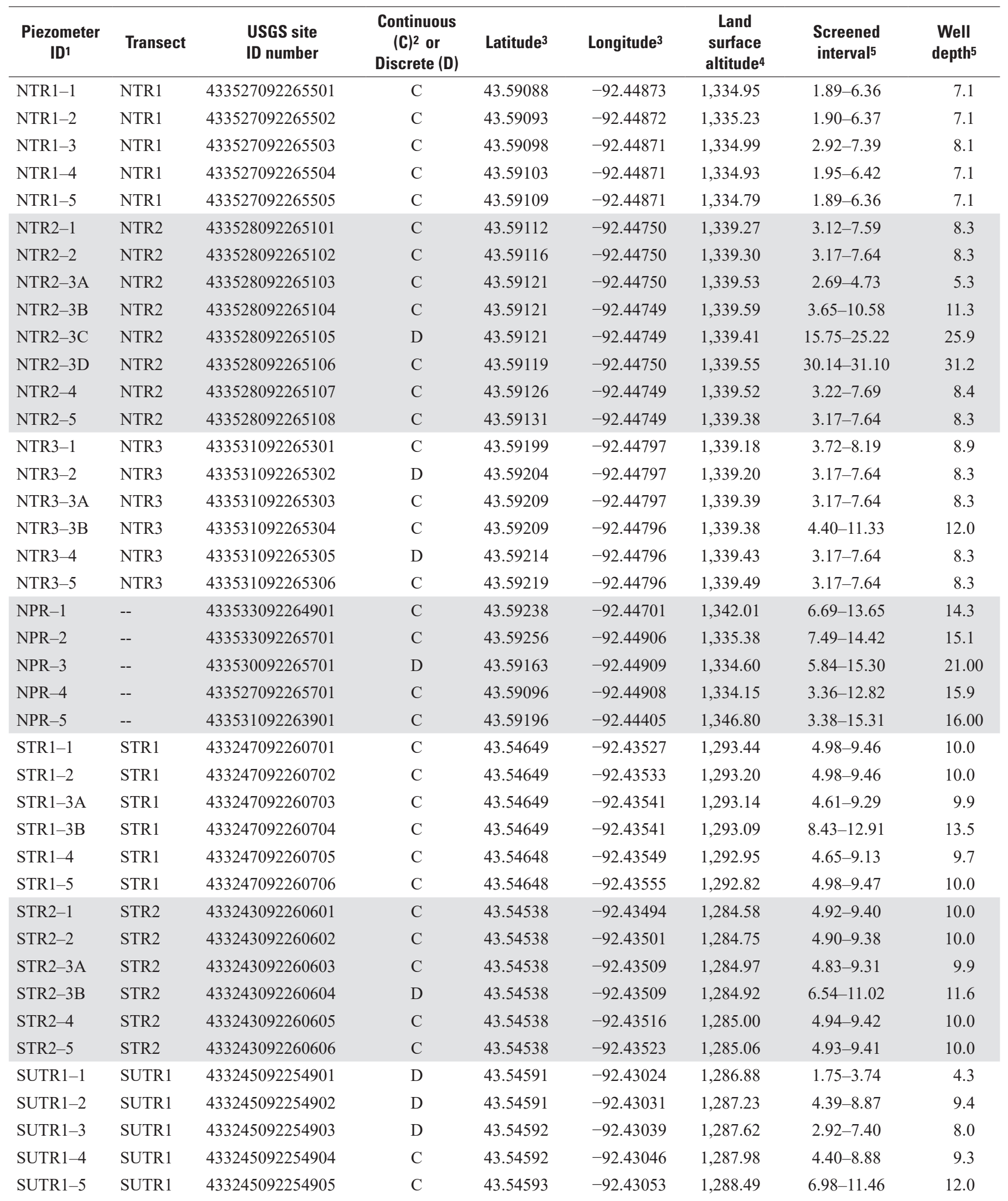


Table 1. Continuous and discrete piezometer network, including piezometer identification (short name), transect array (if applicable), site number, latitude/longitude, land surface altitude, screen intervals, and well depths. - Continued

[ID, identification; USGS, U.S. Geological Survey; --, nontransect]

\begin{tabular}{|c|c|c|c|c|c|c|c|c|}
\hline $\begin{array}{c}\text { Piezometer } \\
\text { ID1 }\end{array}$ & Transect & $\begin{array}{l}\text { USGS site } \\
\text { ID number }\end{array}$ & $\begin{array}{l}\text { Continuous } \\
\text { (C) }{ }^{2} \text { or } \\
\text { Discrete (D) }\end{array}$ & Latitude $^{3}$ & Longitude $^{3}$ & $\begin{array}{c}\text { Land } \\
\text { surface } \\
\text { altitude } 4\end{array}$ & $\begin{array}{c}\text { Screened } \\
\text { interval }^{5}\end{array}$ & $\begin{array}{c}\text { Well } \\
\text { depth }^{5}\end{array}$ \\
\hline SUPR-1 & -- & 433246092254801 & $\mathrm{C}$ & 43.54625 & -92.43015 & $1,283.53$ & $1.73-6.20$ & 6.9 \\
\hline SUPR-2 & -- & 433246092255001 & $\mathrm{C}$ & 43.54621 & -92.43058 & $1,286.47$ & $2.44-6.91$ & 7.6 \\
\hline SUPR-3 & -- & 433244092255001 & $\mathrm{D}$ & 43.54562 & -92.43065 & $1,286.88$ & $3.33-7.80$ & 8.5 \\
\hline SPR-1A & -- & 433242092260901 & $\mathrm{C}$ & 43.54502 & -92.43606 & $1,283.49$ & $5.01-9.49$ & 10.1 \\
\hline SPR-1B & -- & 433242092260902 & $\mathrm{C}$ & 43.54501 & -92.43607 & $1,283.61$ & $35.14-39.45$ & 40.1 \\
\hline SPR-2 & -- & 433249092260801 & $\mathrm{C}$ & 43.54705 & -92.43578 & $1,296.44$ & $9.12-13.60$ & 14.2 \\
\hline SPR-4 & -- & 433249092260501 & $\mathrm{C}$ & 43.54707 & -92.43488 & $1,301.36$ & $9.84-14.32$ & 14.9 \\
\hline
\end{tabular}

${ }^{1}$ The first segment of the piezometer identification includes the piezometer nest (for example, NTR1-1 belongs to NTR1); otherwise, P-label in first segment (for example, NPR-1) designates a perimeter piezometer.

2Piezometers identified with continuous water-table surface elevations have partial or full water-level records from October 1, 2016, through September 30, 2018.

${ }^{3}$ Latitude/longitude in decimal degrees.

4Altitude in feet above the vertical datum, based on North American Vertical Datum 1988 (NAVD 88).

${ }^{5}$ Screened interval and well depth in feet below land surface.

continuous period of record (1936 to the present) and was useful for putting short-term climate data collected within the study area into historical perspective. Based on this longterm record, the mean January temperature was -4.4 degrees Celsius $\left({ }^{\circ} \mathrm{C}\right)\left(24\right.$ degrees Fahrenheit $\left.\left[{ }^{\circ} \mathrm{F}\right]\right)$, the mean July temperature was $27.2^{\circ} \mathrm{C}\left(81^{\circ} \mathrm{F}\right)$, and the mean annual temperature was $7.3^{\circ} \mathrm{C}\left(45.2^{\circ} \mathrm{F}\right)$ (National Climatic Data Center, 2019).

Generally, precipitation increases in early spring after snowmelt from less than 0.8 inch in February to 4.6 inches in June. Rain in spring is considered reliable but decreases throughout the summer. Occasionally, heavy spring rains delay crop planting. Annual precipitation rates can vary dramatically between wet and dry periods, ranging from 15.46 inches (1976) to 43.98 inches (1990). However, annual precipitation has increased in the past three decades (1990-2018) compared to the previous period going back to 1933 (1933-89). The mean annual precipitation from 1933 to 1989 at the Rochester International Airport was 28.9 inches per year, whereas the mean annual sum increased to 34.4 inches per year from 1990 to 2018. Additionally, the number of days with more than 1 inch of precipitation has increased in 1990-2018 compared to the previous period: 5.7 days from 1933 to 1989 , but 7.5 days from 1990 to 2018.

\section{Land Use and Land Cover}

Land use and land cover for the immediate area surrounding the two farmsteads were analyzed to obtain an improved perspective of the land-use setting. Of the selected area, more than 80 percent of the land area was covered by either corn or soybean fields (fig. 4; table 3). The rest of the area was divided between forest, developed land of all types (including roads), and grass/pasture land, with a small amount of land devoted to alfalfa or other hay and peas. These data were obtained from the 2017 Cropland Data Layers (National Agricultural Statistics Service, 2019). Although the various fields would alternate between corn and soybeans, and occasionally alfalfa or other hay, the relative percentages from year to year were largely the same. 
Table 2. Non-piezometer data collection across the three monitoring plots, including soil moisture (volumetric water content), subsurface drainage flow, and meteorological data.

[ID, identification; USGS, U.S. Geological Survey; NSAD, North Site Agri Drain; --, not applicable; SSAD, South Site Agri Drain; NSWS, North Site Weather Station; SSWS, South Site Weather Station]

\begin{tabular}{lllcc}
\hline \multicolumn{1}{c}{ Site ID } & \multicolumn{1}{c}{ Transect } & USGS site ID number & Latitude1 $^{\text {Songitude1 }}$ \\
\hline NTR1-3 & NTR1 & 433527092265503 & \\
NTR1-5 & NTR1 & 433527092265505 & 43.59098 & -92.44871 \\
NTR2-3A & NTR2 & 433528092265103 & 43.59109 & -92.44871 \\
NTR2-5 & NTR2 & 433528092265108 & -92.44750 \\
NTR3-3A & NTR3 & 433531092265303 & -92.44749 \\
NTR3-5 & NTR3 & 433531092265306 & 43.59131 & -92.44797 \\
STR1-3A & STR1 & 433247092260703 & 43.59209 & -92.44796 \\
STR1-5 & STR1 & 433247092260706 & -92.43541 \\
STR1-3A & STR2 & 433243092260603 & 43.59219 & -92.43555 \\
STR1-5 & STR2 & 433243092260606 & 43.54649 & -92.43509 \\
SUTR1-3 & SUTR1 & 433245092254903 & 43.54648 & -92.43523 \\
SUTR1-5 & SUTR1 & 433245092254905 & 43.54538 & -92.43039 \\
\hline & \multicolumn{5}{c}{ Subsurface drain flow } & -92.43053 \\
\hline NSAD & -- & 433527092265601 & 43.54538 & -92.44884 \\
SSAD & -- & 433240092260501 & 43.54593 & -92.43487 \\
\hline & & Meteorological ${ }^{3}$ & \\
\hline NSWS & -- & 433531092263902 & 43.59081 & -92.44405 \\
SSWS & -- & 433241092254601 & 43.54471 & -92.42948 \\
\hline
\end{tabular}

1Latitude/longitude in decimal degrees.

2Each listed soil moisture station included two depths: 1.33 feet and 2.67 feet.

3The meteorological station included the following parameters: air temperature, relative humidity, rainfall, wind speed and direction, and solar radiation.

\section{Methods}

During this study, a large monitoring network was created to capture the groundwater-related water-budget components for three monitoring plots (two drained plots, one undrained plot). Within the monitoring network, continuous water-table surface monitoring, soil volumetric water content monitoring of the unsaturated zone, and subsurface drainage flow monitoring data were collected for 2 water years (2017 and 2018), plus continuous meteorological monitoring (including precipitation) during the same time period. A water year is the 12-month period October 1 , for any given year through September 30, of the following year. From a modeling perspective, the study focused on the recharge calculations and the overall patterns in water-table surface elevations of the piezometer network.

Three different methods were used to derive groundwater recharge. DRAINMOD, a field-scale, process-based, distributed model often used for agricultural fields with subsurface drainage (Skaggs, 1980; Skaggs and others, 2012), was used to simulate subsurface drainage flow, water-table surface elevations, and most importantly, deep seepage rates. The deep seepage rate approximated the expected groundwater recharge to the aquifer below the local restricting layer. The complete DRAINMOD model archives are available as a USGS data release (Smith, 2020a). In addition to deriving potential groundwater recharge rates from the DRAINMOD model, two other methods of estimating potential groundwater recharge were used: (1) an updated Minnesota Soil-Water-Balance (SWB) potential recharge model, and (2) the RISE WaterTable Fluctuation (WTF) method (Rutledge, 1997). In contrast to the DRAINMOD model, these two methods approximate the amount of recharge to the water table closest to land surface. These additional recharge calculations are also available as USGS data releases: the updated Minnesota SWB model (Smith, 2020b) and RISE WTF calculations (Smith, 2020c).

\section{Site Selection Criteria and Extrapolating Results}

Fields were selected that had patterned subsurface drainage, as these fields generally have subsurface drainage with regular spacing, at uniform depths, and all sloping at an equal 


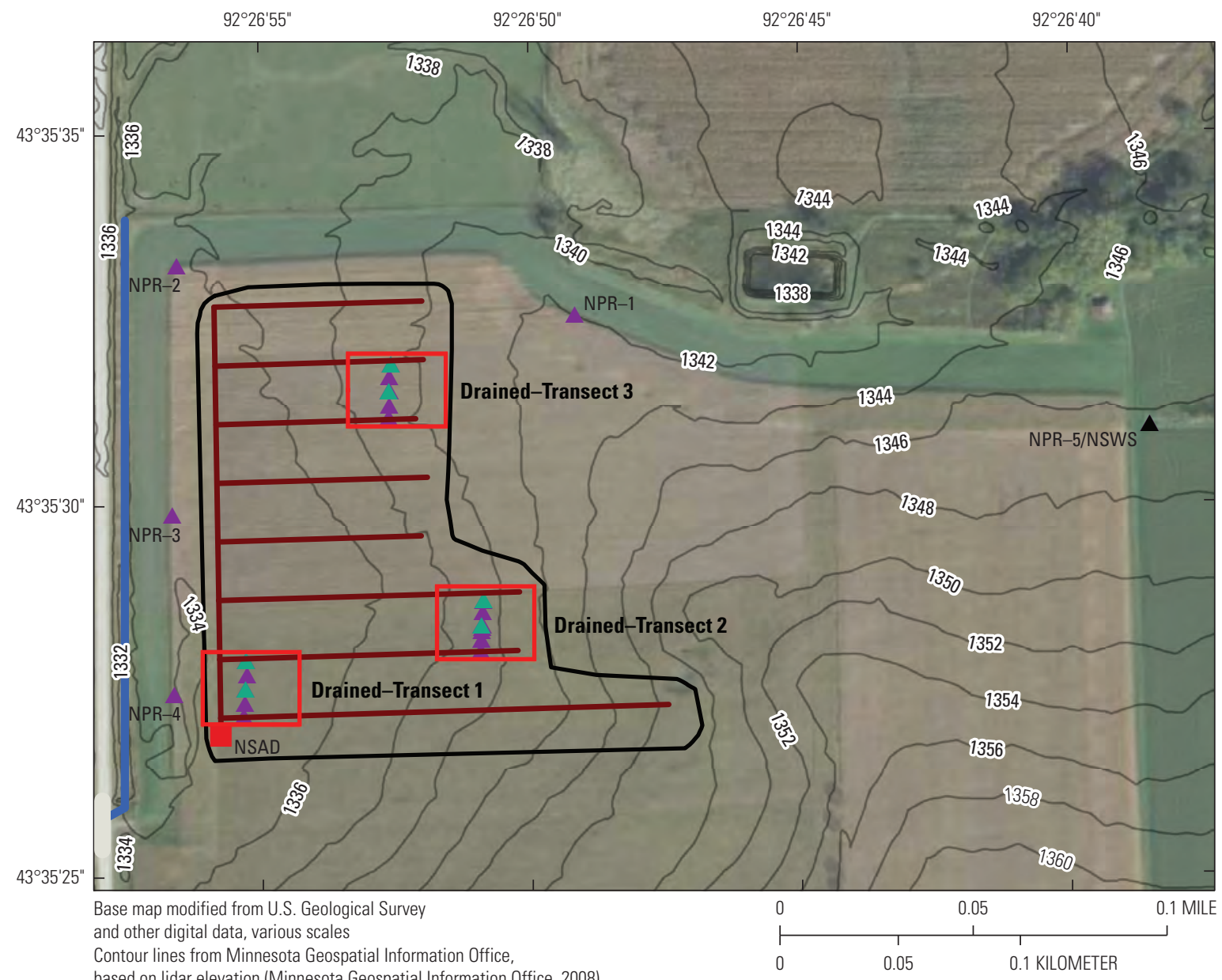

based on lidar elevation (Minnesota Geospatial Information Office, 2008)

Universal Transverse Mercator projection, zone 15 North

North American Datum of 1983, North American Vertical Datum of 1988 (NAVD 88)
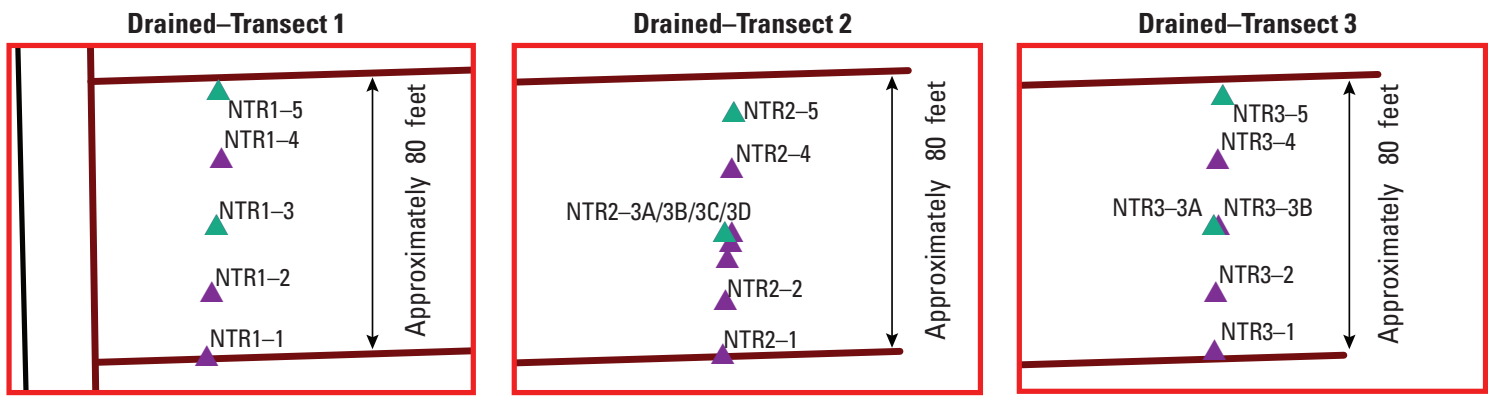

EXPLANATION

[NSAD, North Site Agri Drain; NSWS, North Site Weather Station]

\begin{tabular}{ll}
\hline & Drained site area \\
& North site ditch \\
& Tile line \\
$-1336-\quad$ Land-surface elevation contour
\end{tabular}

Figure 2. Major north drained site locations (Fillmore County, Minnesota), including the piezometer nests, soil moisture probes, meteorological station, and subsurface drainage site. Also shown are the study area extent, parallel and collector subsurface drains, and the surface ditch. 


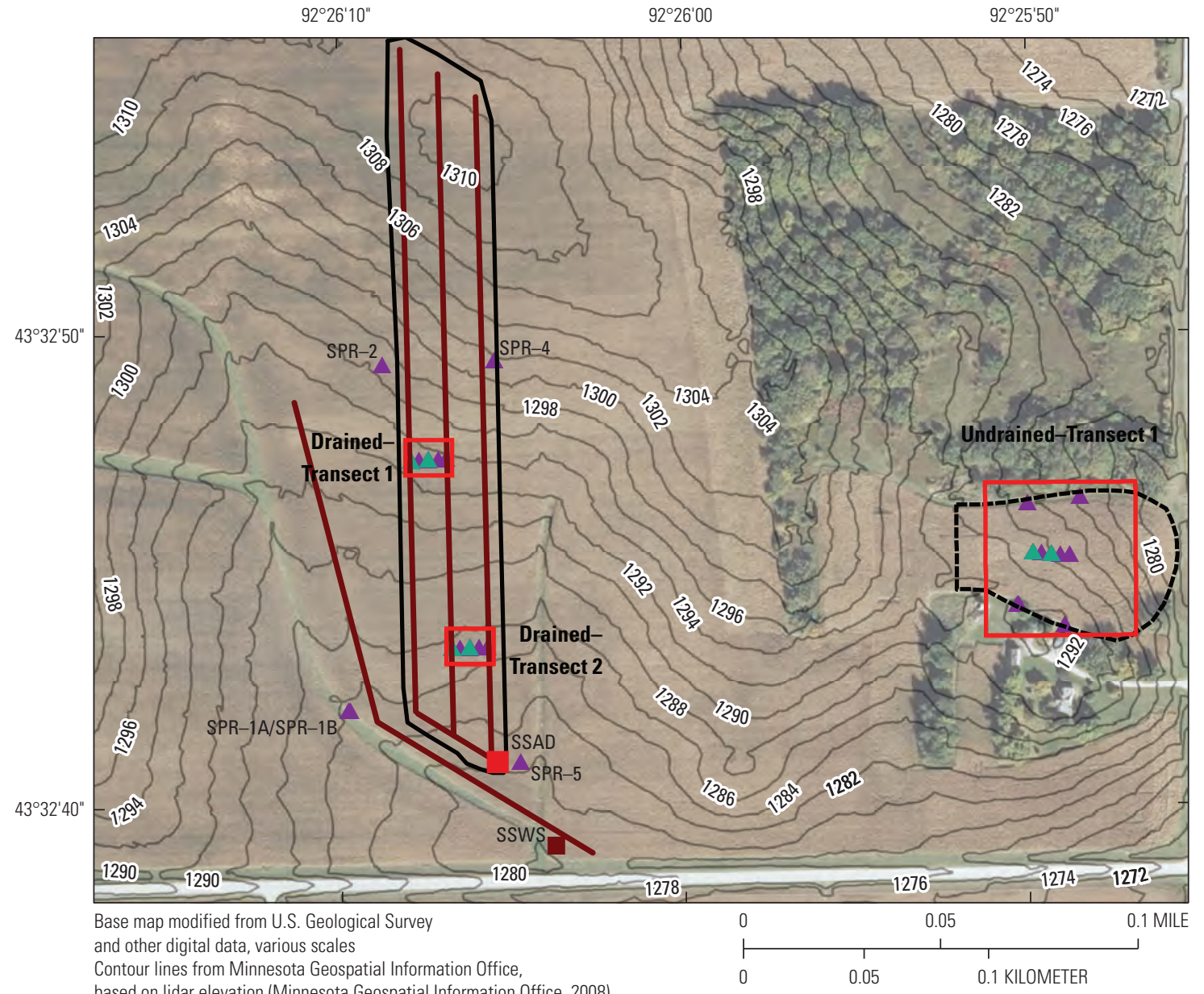

based on lidar elevation (Minnesota Geospatial Information Office, 2008)

Universal Transverse Mercator projection, zone 15 North

North American Datum of 1983, North American Vertical Datum of 1988 (NAVD 88)
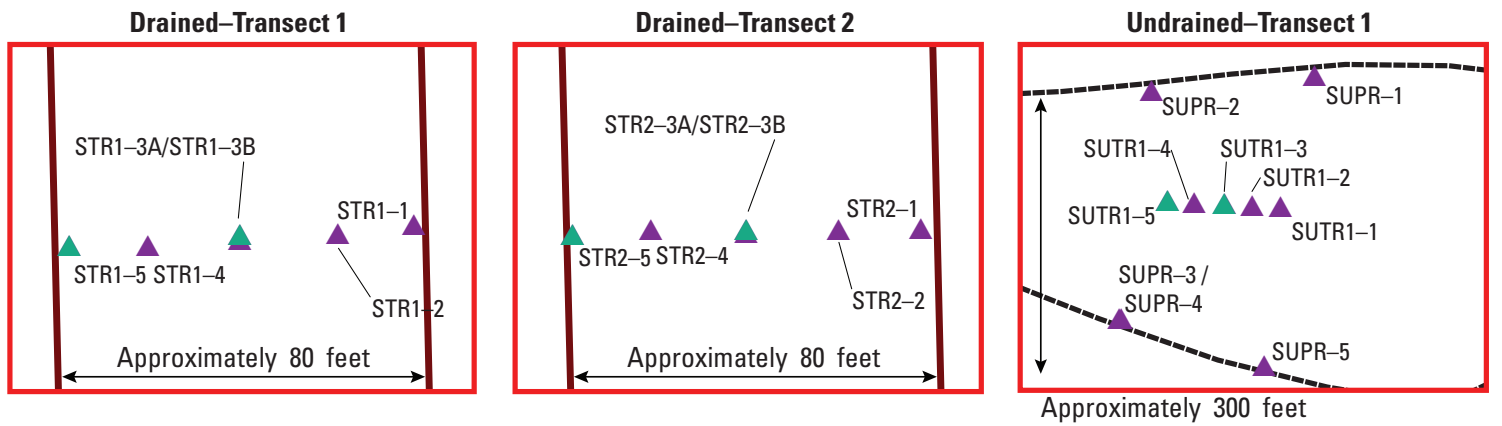

EXPLANATION

[SSAD, South Site Agri Drain; SSWS, South Site Weather Station]

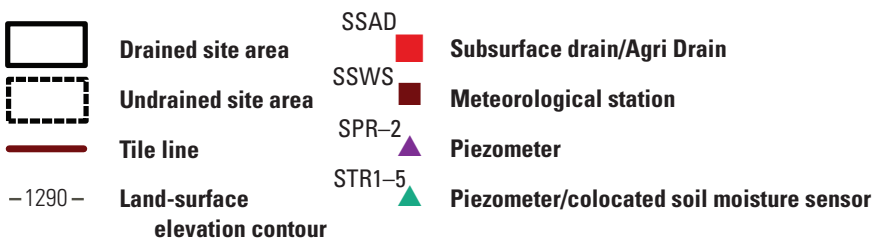

Figure 3. Major south drained and undrained plot locations (Fillmore County, Minnesota), including the piezometer nests, soil moisture probes, meteorological station, and subsurface drainage site. Also shown are the extent of the two study areas, parallel and collector subsurface drains, and the confirmed location of another subsurface drain. 
Table 3. Distribution of land cover in the study area, based on the 2017 Cropland Data Layers (National Agricultural Statistics Service, 2019).

$[<$, less than $]$

\begin{tabular}{lc}
\hline \multicolumn{1}{c}{ Description } & $\begin{array}{c}\text { Land-cover distribution, } \\
\text { in percent }\end{array}$ \\
\hline Corn & 42.1 \\
Soybeans & 38.2 \\
Alfalfa/other hay & 0.9 \\
Barren land (rock/sand/clay) & $<0.1$ \\
Forest (deciduous) & 5.0 \\
Developed, all intensities & 5.8 \\
Grasslands/pasture & 7.5 \\
Herbaceous wetlands & $<0.1$ \\
Peas & 0.4 \\
Open water & 0.1 \\
\hline
\end{tabular}

gradient towards a main (or collector) drain (Smith and others, 2018a). Potential agricultural fields were selected based on the following criteria: depth to bedrock less than 50 feet, slope less than 5 percent, and land use/land cover from the 2011 National Land Cover Database (NLCD) equivalent to pasture/ hay and cultivated crops (Homer and others, 2015). The source for the depth to bedrock paired the 30-meter USGS 1:24,000 scale digital elevation model (DEM) (USGS, 2019a) with the 250-meter resolution bedrock topography grid available from the MGS (Jirsa and others, 2011). Slope data were derived from the same USGS DEM (USGS, 2019a).

The list of potential fields was narrowed down to those with hydrologic soil groups considered favorable for drainage: soil group $\mathrm{A} / \mathrm{D}$, soil group $\mathrm{B} / \mathrm{D}$, soil group $\mathrm{C} / \mathrm{D}$, and soil group D. Hydrologic soil group data were from the Soil Survey Geographic (SSURGO) database (Natural Resources Conservation Service, 2005). The final two agricultural fields in western Fillmore County were selected and landowner permission was obtained after scouting multiple candidate sites in Mower, Fillmore, and Olmsted Counties.

\section{Drained and Undrained Monitoring Plots}

The establishment of the field-scale monitoring plots required the proper mapping of the subsurface drainage layout. The first step was to gather any pertinent drainage maps available and interview the landowners for their general knowledge of the drainage layout. In both plots, the subsurface drainage had been established prior to 1980 , so recollection of the exact layout was unknown. For the north drained plot, the landowner recalled the basic layout although did not possess any drainage maps. For the south drained plot, the landowner did possess old drainage maps that served as a general guide.
The next step was to establish the exact subsurface drain locations. Several methods were considered, including groundpenetrating radar (Allred and Redman, 2010), techniques based on the geographic information system with aerial photographs (Naz and others, 2009), and excavation techniques. Based on available aerial photographs, no discernable drainage patterns were perceptible, and ground-penetrating radar can be difficult in soil types similar to the study fields. Therefore, the best option available was the use of a backhoe to physically excavate to discover the drainage layout (fig. 5).

Once the monitoring plot boundaries were established, the piezometer and soil moisture networks were installed. Most piezometers were installed by the direct push Geoprobe coring method (Geoprobe Systems, 2019), using a 3.25-inch diameter dual tube core barrel. Cores were extracted from all holes, described during collection, and in some cases, preserved for more detailed analysis. Once the target depth for an individual piezometer was attained, all coring augers were extracted. The piezometer, made up of 1.5-inch diameter Campbell Monoflex flush-threaded polyvinyl chloride (PVC), was completely assembled at land surface and then inserted into the open hole. All piezometers installed by this method were back-sealed with a sand pack to above the screen, and then filled close to land surface with dry bentonite and finished with native soils. In the case of deeper piezometers, a hollow stem auger drill was used to open an 8.25-inch diameter hole, with a 2-inch diameter Johnson flush-threaded PVC piezometer installed. The surrounding annulus around the 2-inch diameter piezometer was then backfilled with a sand pack to above the screen, then finally filled with a slurry solution up to land surface (Minnesota Department of Health, 2011).

\section{Core Descriptions}

In addition to the basic field description of cores during piezometer installation, select cores were sent to the MGS for more detailed analysis. The MGS cores were sampled at approximately 2 -inch intervals, with closer sampling extractions at lithologic contacts or where there was variation within units between the contacts. Core sediments were described for texture, grain size and sorting, structure, Munsell color, carbonate content, and level of consolidation. Sixty-two core samples were collected for texture analysis. Particle-size analysis was carried out by staff at the MGS sediment lab. Samples were dry sieved to determine the sand and gravel fraction (greater than 0.063 millimeter) and hydrometer analysis was used to determine the silt and clay fraction (less than 0.063 millimeter).

Lithologic analysis of all collected core samples was performed following Hobbs (1998). For core samples containing 1 gram or more of the 1-2 millimeters very coarse sand fraction, the lithologic composition of individual grains was identified visually using a low power, binocular microscope and placed into categories that were used to identify informal (local) and formally defined stratigraphic units. Core 


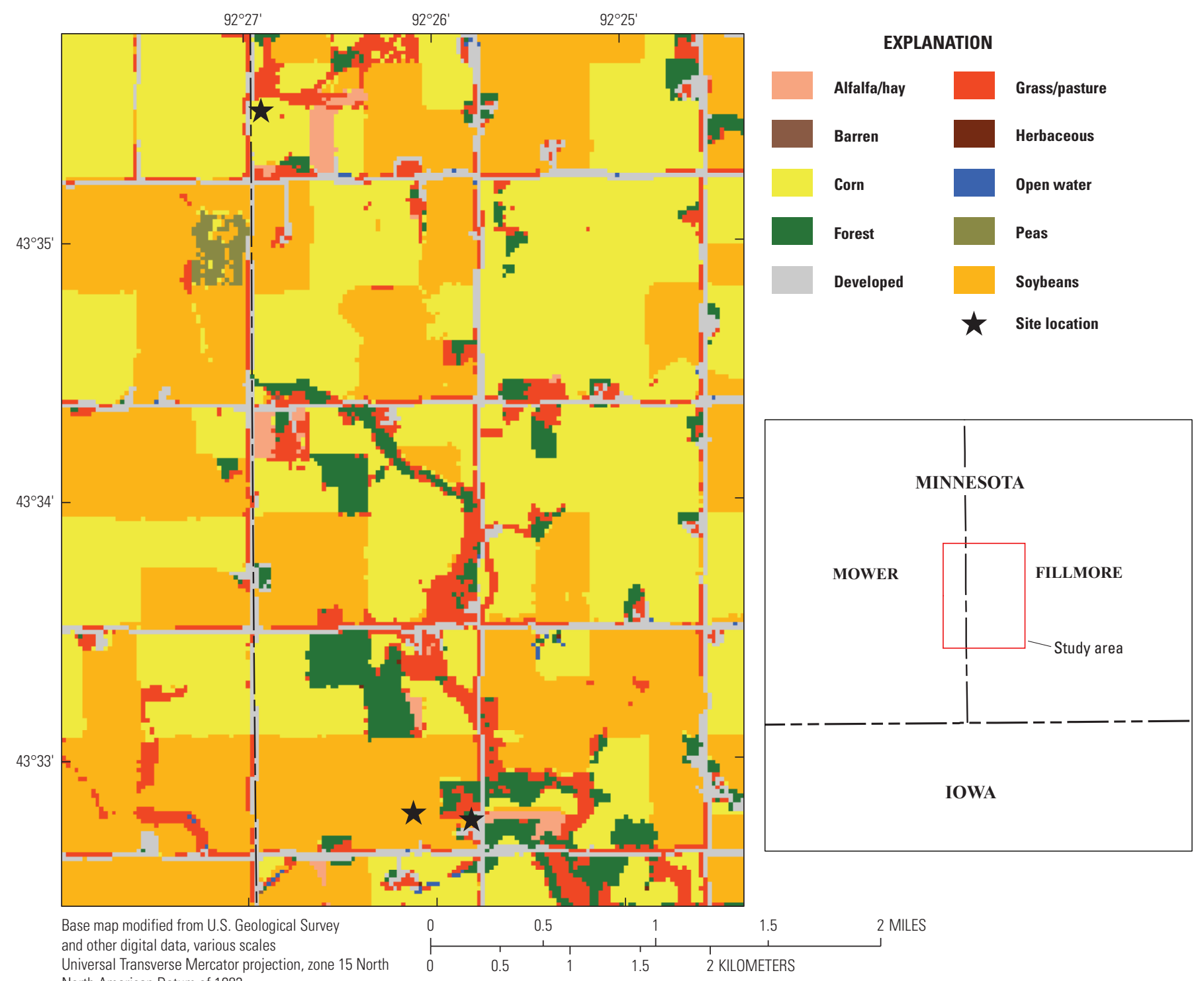

Figure 4. Land cover in the immediate study area around the two farmsteads, at a 30-meter resolution, from the 2017 Cropland Data Layers (National Agricultural Statistics Service, 2019).

description, texture, and lithological data were used to compare the cores to the glacial stratigraphy shown on local maps (for example, Meyer, 2000), and compared to the statewide stratigraphic nomenclature in Johnson and others (2016) to infer the deposit types.

\section{Data Sites}

All piezometers installed for this study are listed in table 1. Site locations are shown in figures 2 and 3. Water-level networks were established for the two drained plots (figs. 2 and 3) and the undrained plot (fig. 3). All other types of data sites, including soil moisture probes, meteorological stations, and subsurface drainage flow sites, are included in table 2 .

\section{Soil Volumetric Water Content Sites}

Soil volumetric water content (VWC) can help characterize the soil antecedent moisture conditions and the overall distribution of water within the soil profile before, during, and after a precipitation event. Soil VWC was determined indirectly by using Decagon 5TM sensors, a specific type of soil moisture probe that measured the water dielectric content as compared to the surrounding soil media (Decagon Devices, 2016). These soil moisture probes were colocated at the six piezometer arrays noted in table 1; each array had a total of four soil moisture probes at two different depths (1.33 and 2.67 feet) and two different locations (figs. 2 and 3; table 2). Daily soil VWC measurements for all sites in table 2 are available online in the USGS National Water Information System (NWIS) database (USGS, 2019b). 


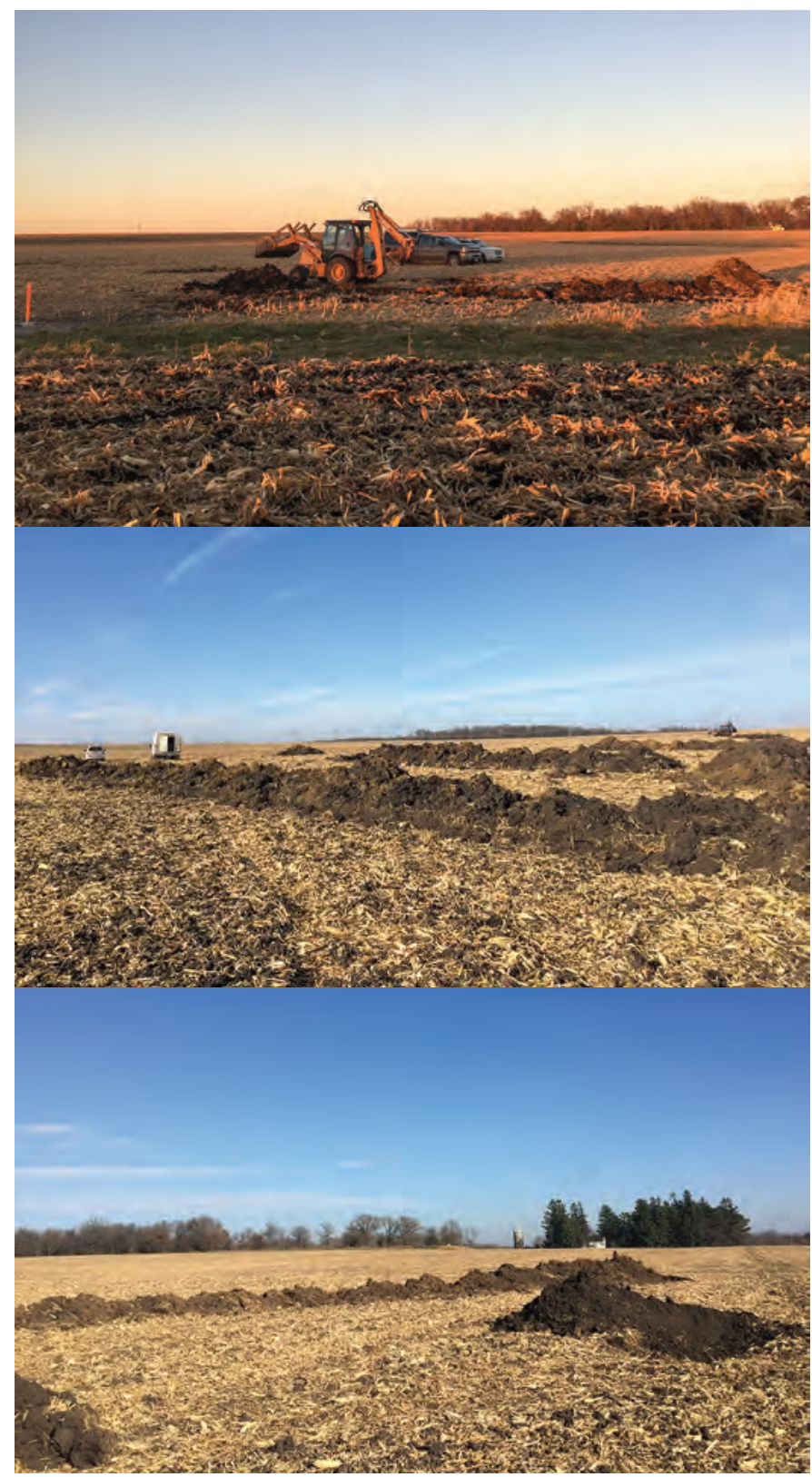

Figure 5. Select photographs from the subsurface drain excavation at the south drained plot, Fillmore County, Minnesota, November 2016.

The overall soil bulk permittivity, or dielectric constant, is governed mainly by the presence of water because the dielectric content of water is 81 as compared to $2-5$ for soil minerals and 1 for air (Muñoz-Carpena, 2004). Measurements were made every 15 minutes, and logged to a Decagon Em50 series data logger. Through a transfer equation, the output voltage was converted to VWC. For more accurate results, a soilspecific calibration equation for the field site was established with cored soil subsections sent directly to the manufacturer of the soil moisture probes (D. Cobos, METER Group, Inc., written commun., August 14, 2018), converting the probe's output (in millivolts) to VWC (fraction).

\section{Groundwater Sites}

Fifty-one piezometers were installed in the three different monitoring plots for this study. The piezometers were strategically located to meet one of three different objectives for the study: (1) provide water levels between two parallel drains, or duplicate the same setup in the case of the undrained plot; (2) provide perimeter water levels in the peripheral, undrained areas; or (3) provide water-level information from the restrictive layer beneath the perched shallow water table. Screened intervals, piezometer depths, and latitude/longitude in decimal degrees are listed in table 1, and are also available online in the NWIS database (USGS, 2019b).

Screened intervals were generally 4.5 feet for the transect piezometers, installed to intersect the water table at the time of installation. Additionally, at least one piezometer was installed slightly deeper for each transect. The screened intervals for the perimeter piezometers varied in screen length but usually had a longer screened interval; perimeter piezometers were installed in the undrained areas of the drained plots and around the perimeter of the undrained monitoring plot. Finally, four piezometers, NTR2-3C, NTR2-3D, SUPR -4 , and SPR-1B, were installed to obtain water-level information from the restricting layer.

The latitude/longitude and all land-surface altitudes in table 1 were obtained by established USGS procedures for using single-base Real-Time Kinematic surveying (Rydlund and Densmore, 2012). The estimated accuracy for the RealTime Kinematic surveying in table 1 is plus or minus 0.003 to 0.02 meter (J. Ayers, USGS hydrologic technician, written commun., 2016).

The basic setup schematic for capturing water levels between two parallel drains and the perimeter area in the undrained areas is shown in figure 6. A total of six different piezometer arrays were set up for this study (table 1) to attain the first objective. Each field piezometer array was set up similar to figure 6 . In addition to the piezometers, two active meteorological stations were set up for this study, subsurface drain flow was monitored for each drained plot, and continuous soil VWC measurements were collected for all six piezometer arrays (table 2). This additional data collection is detailed in separate sections of this report ("Meteorological Sites and Evapotranspiration Calculations" and "Subsurface Drainage Flow Monitoring Sites").

Piezometers with continuous water levels (table 1) were outfitted with one of three types of submersible pressure transducers to measure water level. Most submersible pressure transducers were Levelogger Edge (model 3001) pressure transducers, rated with a full-scale accuracy of 0.05 percent (Solinst, 2014). Because these transducers measure water and atmospheric pressure, each separate plot required one primary and one backup pressure transducer (Barologger Edge; model 3001) that recorded barometric pressure to compensate for the atmospheric pressure to calculate the final water-level measurement. For a few of the deeper piezometers, OTT Orpheus mini pressure transducers, which do not require external 
compensation because they use vented pressure cells, were used (OTT HydroMet, 2019). Finally, a total of four piezometers and both subsurface drainage flow monitoring stations were outfitted with an LTC Levelogger Edge (model 3001).

All data were internally logged in the transducer and uploaded to the USGS NWIS database semiannually. Data collection and processing were completed according to standard USGS protocol and internal Upper Midwest Water Science Center practices, including periodic manual water-level verification by steel tape or electric tape. These data are available from the NWIS database (USGS, 2019b) for all continuous sites (table 1). In addition to continuous water-level sites, a subset of the study piezometers was measured (discrete sites in table 1) during scheduled field visits to provide the general trends for non-continuous water-level sites. All groundwaterlevel measurements, including calibration checks, were obtained by steel tape or electric tape, following the procedures of Cunningham and Schalk (2011). These data for the discrete sites also are available from the NWIS database (USGS, 2019b).

\section{Meteorological Sites and Evapotranspiration Calculations}

Two meteorological stations were installed for this study, the North Site Weather Station and the South Site Weather Station (SSWS), one for each of the two agricultural fields. Because the south drained plot and the undrained plot were at the same farmstead, only one meteorological station was used (SSWS). Both meteorological stations used a HOBO U30-NRC with the standard plug-in sensors that accompany the basic meteorological station (Onset Computer Corporation, 2016). For both stations, the following parameters were collected every 15 minutes: air temperature (in degrees Celsius), wind direction (from true north), wind speed (in meters per second), relative humidity (in percent), and net solar radiation (in watts per square meter). Daily summaries of the median, mean, minimum, and maximum statistics for all collected parameters are available from the NWIS database (USGS, 2019b).

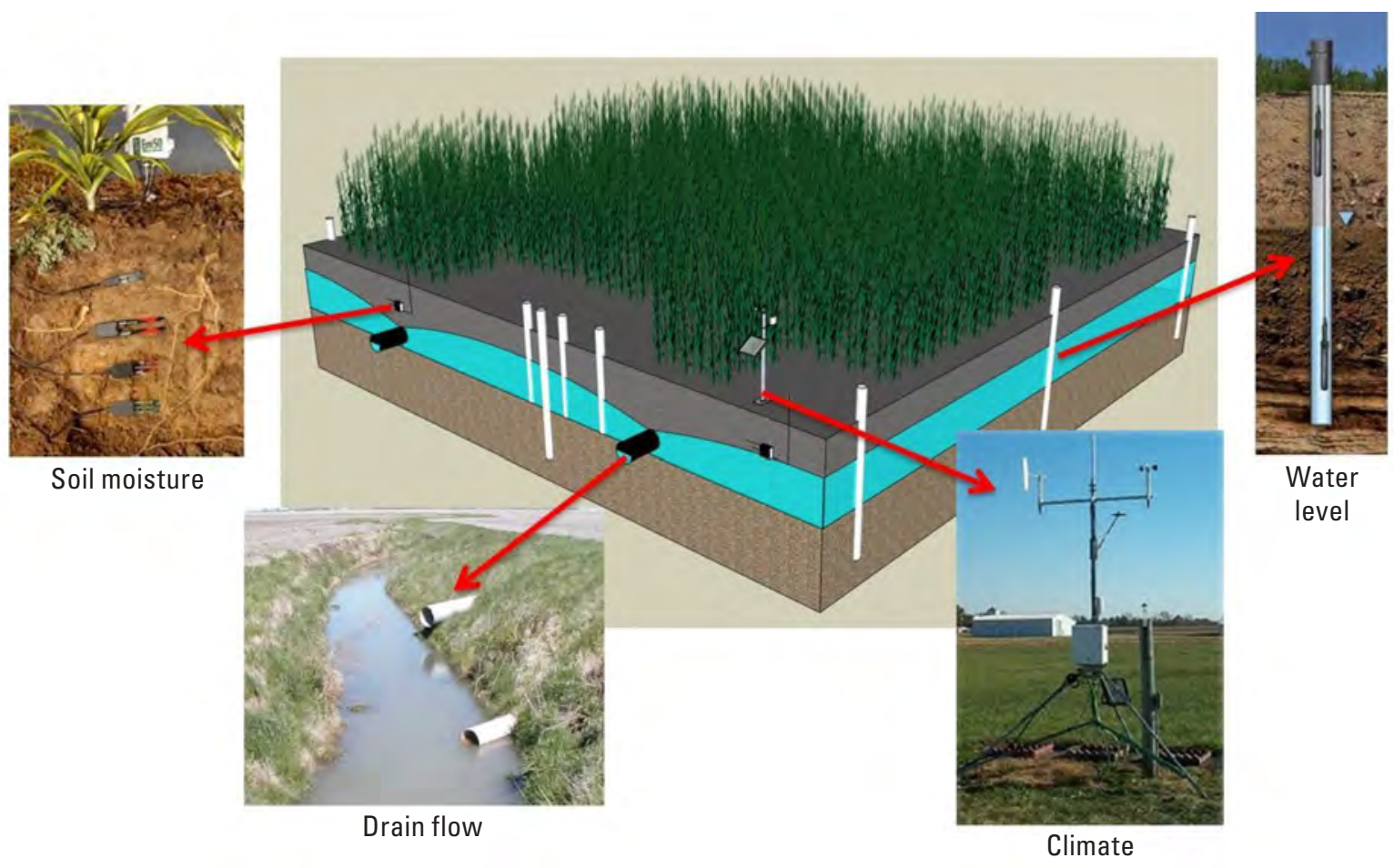

Figure 6. A hypothetical configuration of one of the two drained field plots, including the meteorological station, a piezometer transect for continuous water-level measurements between two parallel subsurface drains, perimeter piezometers for background water-level measurements, soil moisture probes, and subsurface drainage flow. The undrained plot had a similar configuration, with the absence of subsurface drainage flow. Center graphic by Jason Roth, Natural Resources Conservation Service. 
Internal logging precipitation gages were colocated next to both meteorological stations. The precipitation gages consisted of a tipping bucket-type rain gage to obtain accurate measurements of local precipitation during the nonfreezing part of the year, recorded in 0.01-inch increments and aggregated into 15-minute intervals. During the semiannual downloads, both rain gages were cleaned and calibrated. Also, during the regular synoptic surveys, both rain gages were checked for any obstructions and cleaned, if necessary. Precipitation data by site location are available from the NWIS database (USGS, 2019b).

Based on the meteorological data collected for this study, daily potential ET rates were calculated by the Food and Agriculture Organization Penman-Monteith method (Allen and others, 1998). All required climate data, such as net solar radiation, wind speed, air temperature, and vapor pressure (derived from a combination of air temperature and relative humidity) were obtained from the two local stations. The Food and Agriculture Organization Penman-Monteith method is shown in equation 1:

$$
E T_{0}=\frac{0.408 \Delta\left(R_{n}-G\right)+\gamma_{T T}^{900} 27 u_{2}\left(e_{s}-e_{a}\right)}{\Delta+\gamma\left(1+0.34 u_{2}\right)}
$$

where

$$
\begin{aligned}
& E T_{0} \quad \text { is potential evapotranspiration, in } \\
& \text { millimeters per day; } \\
& \Delta \quad \text { is slope vapor pressure curve, in kilopascals } \\
& \text { per degree Celsius; } \\
& R_{n} \quad \text { is net radiation at the crop surface, in } \\
& \text { megajoules per meter per day; } \\
& G \quad \text { is soil heat flux density, in megajoules per } \\
& \text { meter per day; } \\
& \gamma \quad \text { is the psychrometric constant, in kilopascals } \\
& \text { per degree Celsius; } \\
& T \quad \text { is mean daily air temperature at } 2 \text { meters } \\
& \text { height, in degrees Celsius; } \\
& u_{2} \quad \text { is wind speed at } 2 \text { meters height, in meters } \\
& \text { per second; } \\
& e_{s} \quad \text { is saturation vapor pressure, in } \\
& \text { kilopascals; and } \\
& e_{a} \quad \text { is actual vapor pressure, in kilopascals. }
\end{aligned}
$$

Daily ET calculations were calculated from August 27, 2016, through October 30, 2018, for comparisons to the Thornthwaite ET calculations done internally within the DRAINMOD model (Thornthwaite, 1948). In a few instances, the derived ET rates were substituted into the DRAINMOD model in lieu of the internally calculated rates.

\section{Subsurface Drainage Flow Monitoring Sites}

The tile drainage flow rates were collected for both drained plots using a combination of an inline water-level control structure, an area velocity (AV) module (Teledyne ISCO 2150), and a pressure transducer. The North Site Agri Drain (NSAD) estimated the tile drain flow for the north drained plot, and the South Site Agri Drain (SSAD) estimated the tile drain flow for the south drained plot. This technique was primarily based on setup information provided by Scott Matteson of the Minnesota Department of Agriculture (MDA), and currently is in use at several MDA sites including Minnesota Discovery Farms. The discharge rating equations were developed through rigorous testing by the MDA at Saint Anthony Falls Laboratory in Minneapolis, Minn. (S. Matteson, MDA research scientist, written commun., November 10, 2016).

The basic plot configuration consisted of locating the main collector tile drain that aggregated all parallel tile in the field, and then selecting a section downstream from the study area while still upstream from the outflow to avoid backflow as much as possible. Once the section was located, the tile was exposed at least 15 feet on the upstream and downstream sections of where the tile was to be broken (fig. 7). After the area was exposed, the tile was cut, an approximately 24-foot tile section was completely removed, and the inline water-level control structure was set into place; all work was completed in mid-November when subsurface drain flow was minimal but before the ground was frozen. The inline water-level control structure, typically used to manage the infield water table, was used in this study for tile access to control the flow conditions through the drain (Agri Drain Corporation, 2019). While setting the control structure, further construction efforts included upsizing the subsurface drain from 6 to 8 inches 10 feet upstream and downstream from the control structure. In effect, the control structure allowed for unimpeded gravity flow through one end of the structure and out the other into the downstream PVC section.

Before sealing the upstream section to the control structure, the AV module sensor was top-mounted on the upstream section and the sensor cables were pulled up to the surface through the top of the control structure. Once the control structure was properly sealed and ensured to be in a level position, the excavated section of subsurface drain was backfilled and leveled out. Certain considerations for the drainage flow monitoring setup were included with this study, based on the methods shared by the MDA, including (1) a smooth-walled subsurface drain upstream and downstream from the Agri Drain for at least 10 feet in each direction, avoiding choppy and turbulent flow as much as possible; (2) stoplogs within the Agri Drain to fully submerge the upstream subsurface drain during active flow periods; and (3) a top-mounted AV module to avoid flow disturbances and sedimentation issues.

Subsurface drainage flow measurements were based on a combination of water-level information from the Teledyne ISCO $2150 \mathrm{AV}$ flow module and the LTC Levelogger Edge. To convert the water-level data into discharge, a flow calculation based on stage discharge equations established by the MDA was used (S. Matteson, MDA research scientist, written commun., November 10, 2016). The stage discharge relation was based on flow through a V-notch weir. Because the normal purpose of an Agri Drain is for controlled drainage, vertical stoplogs can be used to hold back the water in the field. For this study, two stoplogs were placed at the bottom to 


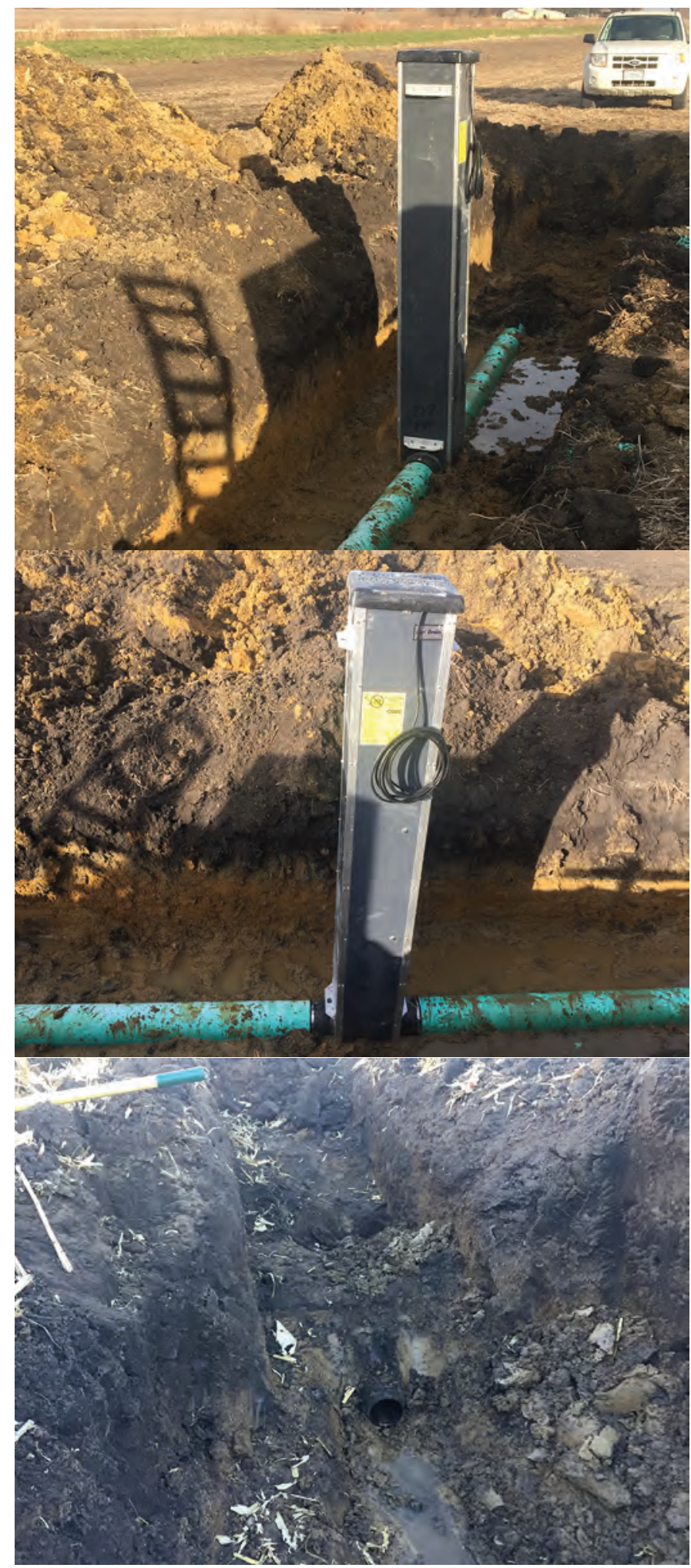

Figure 7. Select photographs from the subsurface drain flow monitoring installation at the north drained plot, Fillmore County, Minnesota, November 2016. prevent unimpeded flow through the drain. The first stoplog was 7 inches ( 0.58 foot) tall, with a second stoplog above this stoplog of 12 inches (1 foot). Within the 12-inch stoplog, a 0.529-foot, 46-degree V-notch was cut to allow for controlled flow from the upstream side to the downstream side of the tile. Based on MDA testing, the following V-notch weir equations (eqs. 2 and 3) were used to calculate drainage flow in cubic feet per second; also shown is the coefficient of determination $\left(R^{2}\right)$ for the following equations. For $h$ less than 0.35 foot from bottom of $\mathrm{V}$-notch $\left(R^{2}=0.99\right)$ :

$$
D=\left(0.8045 \times h^{2}\right)+0.0115 h,
$$

For $h$ from 0.35 to 0.529 foot from bottom of V-notch $\left(R^{2}=0.99\right)$

$$
D=1.0728 \times h^{2.1694,}
$$

where

$$
\begin{gathered}
D \quad \text { is subsurface drainage flow, in cubic feet per } \\
\text { second; and } \\
\text { is height above bottom of V-notch } \\
\text { weir, in feet. }
\end{gathered}
$$

Subsurface drainage flow was calculated every 15 minutes, with the Levelogger used as the primary record and the ISCO-derived water level as a backup. For NSAD, 15-minute flow was calculated from April 11, 2017, through September 26, 2018, and for SSAD, flow was calculated from April 11, 2017, through October 30, 2018. For NSAD, because of the failure of the AV module and a gap in the Levelogger record, approximately 2 weeks of flow were missing from October 17 to November 2, 2017. The 15-minute drainage flow for NSAD and SSAD, in cubic feet per second and cubic meters per second, respectively, are provided in appendix 1 . The daily subsurface drain flow per day for NSAD and SSAD, in cubic feet per day and cubic meters per day, respectively, are provided in appendix 2 .

\section{DRAINMOD Model}

The DRAINMOD model can be used to quantify multiple water-budget components for poorly drained, high watertable soils (Skaggs, 1980; Skaggs and others, 2012). Some of the primary water-budget components include runoff, ET, subsurface drainage, subirrigation, lateral seepage, and deep seepage. The typical application for the DRAINMOD model is for agricultural fields with parallel drains. Although several other field-scale models exist for agricultural fields besides DRAINMOD, such as ADAPT (Alexander, 1988) or WEPP (U.S. Department of Agriculture, 1995), the DRAINMOD model is easy to use, explicitly simulates subsurface drainage and deep seepage, and has a long publication history for hundreds of applications (North Carolina State University, 2019). 
The basic DRAINMOD model setup extends from the ground surface to the impermeable layer below for a section of soil of unit surface area (Skaggs and others, 2012). Because the basic DRAINMOD model is set up for parallel drains, the physical location for the water balance is midway between the two parallel drains. The underlying DRAINMOD model water balance used for this study's application, based on any water storage differences for the section of soil of unit surface area, can be quantified by equations 4 and 5 on a daily basis:

$$
\begin{gathered}
\Delta V=D+E T+P R-F, \\
P=F+S+R_{\mathrm{o}},
\end{gathered}
$$

where

$\begin{array}{cl}\Delta V & \text { is change in water free pore space, in } \\ & \text { centimeters per day; } \\ D & \text { is subsurface drainage, in centimeters per day; } \\ E T & \text { is evapotranspiration, in centimeters per day; } \\ P R & \text { is deep seepage or potential groundwater } \\ & \text { recharge, in centimeters per day; } \\ F & \text { is infiltration, in centimeters per day; } \\ P & \text { is precipitation, in centimeters per day; } \\ S & \text { is change in volume of surface water stored, } \\ & \text { in centimeters per day; and } \\ R_{\mathrm{o}} & \text { is surface runoff, in centimeters per day. }\end{array}$

Beyond the basic water balance (eqs. 4 and 5), the DRAINMOD model fully synthesizes the basic hydrologic cycle for the agricultural field on a daily basis, and in the case of days with any precipitation or melting event, on an hourly basis. Some of the most important sets of parameters related to defining the soil water distributions, water-table fluxes, and Green-Ampt parameters are all based on the soil type used for the DRAINMOD model runs (Skaggs, 1980). Because these parameters can be difficult to estimate, the simplest method was to use another program to define these parameters. A utility inside of the DRAINMOD model automatically determined these parameters by providing the soil layering information and the relation between VWC, in cubic centimeters per cubic centimeter, and pressure head in centimeters of water. However, the VWC-pressure head relations must first be independently derived from another source. Because soil type for each location can be derived from the SSURGO database, the SSURGO soil information was input into another model called Rosetta (Agricultural Research Service, 1999). Rosetta only required soil layer depths and the soil textural data, both obtained from the SSURGO database. The Rosetta model calculated several intermediate parameters, such as saturated conductivity and the saturated and residual water contents, which then can be input into equation 21 from van Genuchten (1980) to calculate the VWC-pressure relation.

Other DRAINMOD parameters related to vertical seepage were important for calculating the piezometer water level and deep seepage rate (Skaggs, 1980; Skaggs and others, 2012). These parameters included the piezometric head of the aquifer below the restricting layer, the vertical conductivity of the restricting layer, and the restricting layer thickness. Parameters that defined drainage rates included the subsurface drain depth below land surface, drain spacing, the effective drain radius, and the drainage coefficient. Several of these parameters were known from field measurements, whereas others were fitted by successive model iterations. Additional theoretical and background details on the DRAINMOD model are best described by Skaggs (1980), the DRAINMOD reference report. Additional details in Skaggs (1980) include specifications for all the model subroutines, how the model handles the different hydrological components, setting up the input files, and all necessary parameters for running the model.

DRAINMOD models were completed for a total of nine different sites. Five of the DRAINMOD models were done for the piezometer arrays at the two drained plots, whereas the other four DRAINMOD models were completed for nondrained, perimeter sites. For the piezometer transects between tile drains, the piezometer in the middle was used unless the record just off of the middle was a more complete record. For the four perimeter piezometers used for the DRAINMOD model (NPR-4, NPR-5, SPR-2, SPR-5; table 1), the drainage coefficient was set to zero and the drain spacing was set to 180 meters, in effect zeroing out any potential drainage and thereby simulating the potential deep seepage rates that would happen without drainage. Although the distance of the actual piezometers was less than 180 meters from the nearest tile, this was a recommended setting to eliminate any possible drainage modeling because it is not possible to use the DRAINMOD model without drainage. Additionally, attempts were made for several of the records at the undrained plot, but the records were all too truncated because most of the waterlevel records were below piezometer screen depth. The complete DRAINMOD model archives are available as a USGS data release (Smith, 2020a). Additionally, the van Genuchtenderived (1980) VWC-pressure head relations, as calculated for the soil types used for the DRAINMOD model, are part of the model archive.

Two statistics were used to evaluate performance of the individual DRAINMOD models against the measured water levels: mean absolute error (MAE, in centimeters) and the Nash-Sutcliffe index of efficiency (NSI) (Nash and Sutcliffe, 1970). The MAE, computed by equation 6 (for example, see in Smith and others, 2018b), is the mean difference between the absolute values of the simulated (model) and the measured values:

$$
\mathrm{MAE}=\frac{1}{n} \sum_{l=1}^{n} \mid \text { simulated value }- \text { measured value } \mid
$$

where

$n \quad$ is the number of observations.

For comparison purposes, the output for DRAINMOD water levels was centimeters. These units were preserved for discussion purposes, as this is the common unit used in other DRAINMOD model publications (Skaggs and others, 2012). 
The other goodness-of-fit statistic, the NSI, has been classically used to evaluate hydrological model performance (Legates and McCabe, 1999). The NSI ranges from minus infinity to positive 1.0. Any value above 0.0 indicates that the model is a better predictor of the measured data than the mean of the measured data, with 1.0 indicating a perfect match. NSI values below 0.0 indicate the mean of the measured data is a better predictor than the model values.

\section{Recharge}

Two other methods were used to estimate potential groundwater recharge for the monitoring plots. The two methods, the RISE WTF method (Lorenz, 2016) and the SWB model (Westenbroek and others, 2018), have been used in multiple studies. For the SWB model analysis, a previously published SWB model was used (Smith and Westenbroek, 2015) and updated to the latest version of the SWB model.

\section{RISE Water-Table Fluctuation Method}

The continuous water-level data collected for this study were used to estimate potential groundwater recharge using a WTF method (Delin and others, 2007; Lorenz, 2016). The selected Water-Table Fluctuation method uses the RISE program to estimate recharge from the product of groundwaterlevel rises and specific yield. This approach is based on the RISE WTF method for computing recharge from Rutledge (1997), which was designed for characterizing diffuse areal recharge to the water table. This method assumed that recharge could be restricted to small time increments in hydrologic settings with thin unsaturated zones, such as the unsaturated zone in all three monitoring plots.

As part of the DVstats package (Lorenz, 2016) for the R statistical environment (RStudio Team, 2019), potential groundwater recharge was calculated based on first calculating the daily rise events during the course of the groundwater record and subsequently aggregating the rise events into recharge events based on a preset specific yield. The RISE program was used to analyze the record for groundwaterlevel rises, and a second $\mathrm{R}$ function, aggregate (also part of DVstats), summed up the rising portions of the groundwater rises and multiplied these rises by the specific yield to calculate groundwater recharge. Based on the common surficial aquifer materials of silty loam in the study area, a specific yield value of 10 percent was used for all piezometers (Johnson, 1967).

\section{Soil-Water-Balance Method}

The SWB model was used as a third method for estimating groundwater recharge. The SWB model uses a modified Thornthwaite-Mather SWB approach (Thornthwaite and Mather, 1957). The water-balance approach of the SWB model estimates potential recharge (Westenbroek and others,
2010) on a daily basis. The original Minnesota SWB model (Smith and Westenbroek, 2015) developed statewide gridded estimates of mean potential groundwater recharge from 1996 through 2010 at a 1-kilometer (0.621-mile) resolution. For this study, the framework of that original model was used and updated to SWB Version 2.0 to overlap the SWB model with the study period.

The SWB model uses a soil-water accounting method to calculate potential recharge for each grid cell in the model domain separately (Westenbroek and others, 2010, 2018). Computation of water-budget components relies on relations among surface runoff, land cover, hydrologic soil group, maximum soil-water capacity, ET estimates, and temperature. Within the SWB approach, potential recharge is calculated within each grid cell of the model domain based on the difference among sources (precipitation, snowmelt, inflow), sinks (interception, runoff, evapotranspiration), and changes in soil moisture. Additional theoretical and background details on the SWB model were described by Westenbroek and others (2010) and in the newer SWB model version (SWB Version 2.0) used for this study (Westenbroek and others, 2018). Further details pertaining to the Minnesota SWB model were included in Smith and Westenbroek (2015), particularly the calibration process for the soil and land-cover lookup table.

For this report, the same lookup table from the published statewide SWB model (Smith and Westenbroek, 2015) was used for re-running the statewide SWB model during 2014-18, including necessary climatic data such as daily precipitation, minimum daily temperature, and maximum daily temperature. It was assumed the original lookup table applied for this new time period, because a robust calibration across the entire State was performed from 1996 to 2010 for the original Minnesota SWB model (Smith and Westenbroek, 2015). The lack of a new calibration is a limitation of the new SWB model period, but a full calibration was out of scope for this study. All meteorological data were provided by the Daymet dataset, which included daily continuous surfaces of key climatological data (Thornton and others, 2018). Land use was updated to NLCD 2011 (Homer and others, 2015). All other parts for the 2014-18 re-run (Smith, 2020b) were the same as for the original Minnesota SWB model. The SWB model results were used for the following two purposes: (1) to compare extracted SWB potential recharge rates to the RISE WTF and the DRAINMOD model recharge estimates; and (2) to extract the potential recharge rates for other areas of southeastern Minnesota with landscape characteristics similar as those in the study.

\section{Core Descriptions and Unit Interpretations}

Cores from the three monitoring plots were sent for interpretation of grain size distributions, lithological descriptions, and deposit type interpretations. Four cores were selected for 
detailed analysis from the north drained plot (table 4). Across the cores, there was a high degree of heterogeneity, although in general the cores included less sand and more clay with depth, with variable amounts of silt throughout the cores (table 4).

Most samples across the north drained plot cores had either a loam or silty clay loam texture, based on the U.S. Department of Agriculture texture classification (U.S. Department of Agriculture, 1999), with a few samples classified as sandy loam or silty loam. All cores had between 1 and 2 feet of top soil, followed mostly by till deposits. For NPR-3, two different layers of lacustrine sediments were found that contained a high amount of silt and clay and low amounts of sand, likely acting locally as restricting layers. However, in general, most of the site deposits had characteristics that indicate low vertical hydraulic conductivities.

Three cores were selected for the south monitoring plots (table 4), with two drained plot cores and one undrained plot core. Relative to the north drained plot, these cores did exhibit general heterogeneity, but not as much heterogeneity with depth. Both cores for the drained plot had a fairly even mix of sand and clay with depth (approximately $20-35$ percent), with the rest identified as silt size and gravel. The undrained plot core was very different than drained plot cores, with a very high amount of silt throughout the core (table 4).

Most samples across these cores had either a loam or clay loam texture, based on the U.S. Department of Agriculture texture classification (U.S. Department of Agriculture, 1999), with a few samples classified as silt loam and silty clay. Both drained plot cores had approximately 2 feet of top soil, followed mostly by till deposits. Unlike the north drained plot, there were not any lacustrine deposits at the drained plot. These deposits would still have lower hydraulic conductivities, but not likely as low as the north drained plot. For the undrained plot, most of the core was identified as either lacustrine or loess. 


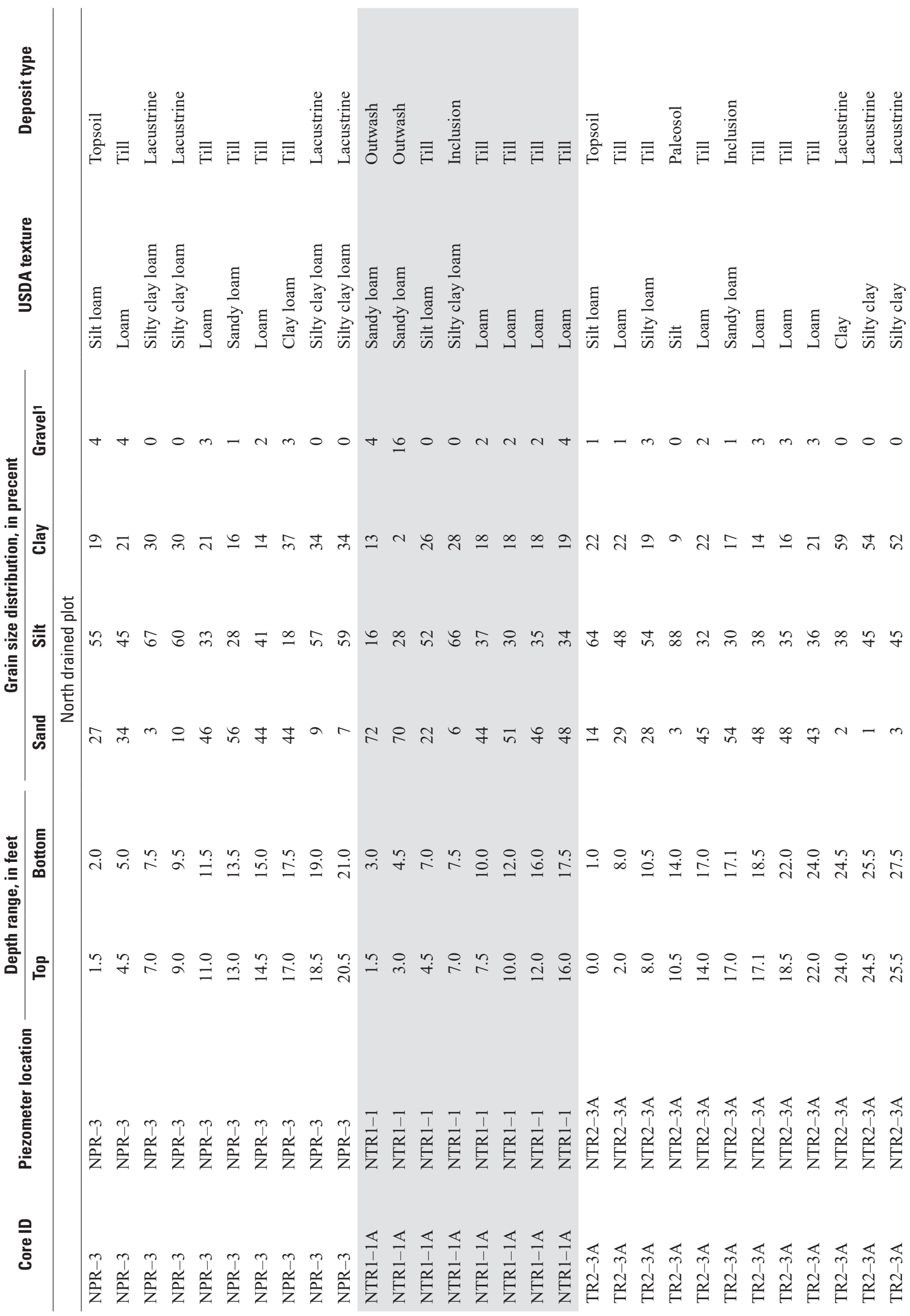




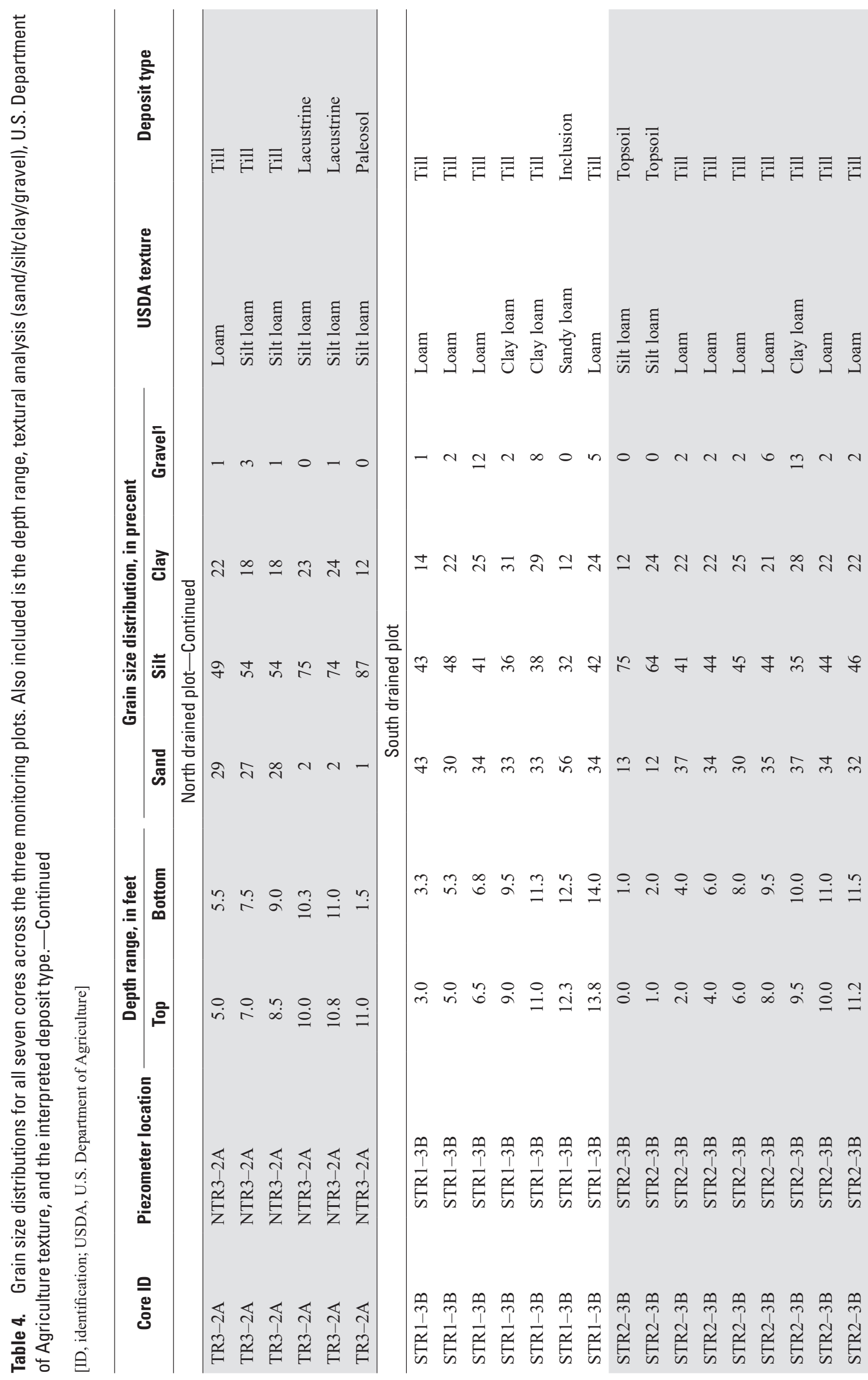




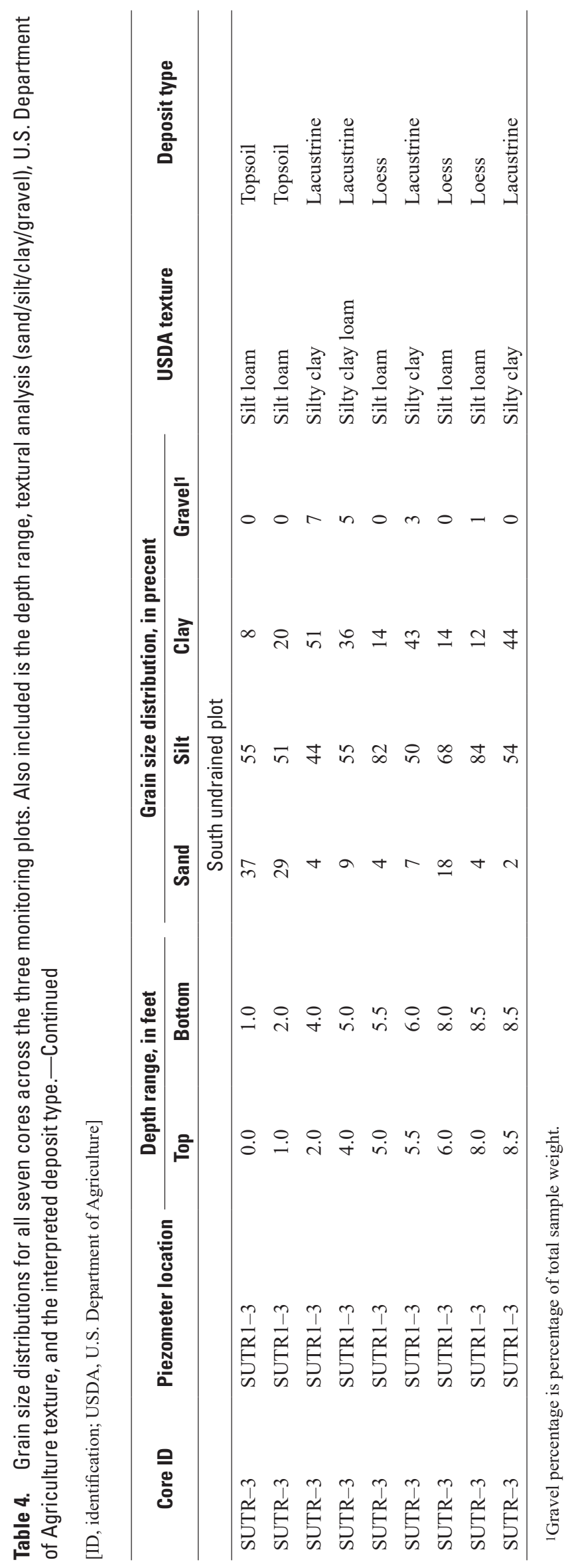




\section{Water-Budget Components-Patterns}

The hydrologic budget analysis for this report is focused on the spatial and temporal water-table surface elevation variations. Additionally, the soil VWC time series and the subsurface drainage flow was interpreted as part of the hydrologic budget analysis. Aside from providing insights into the hydrologic flow pathways, the individual water-budget components were used as calibration datasets for the DRAINMOD model and RISE WTF models.

\section{Soil Moisture Conditions}

Soil moisture conditions were measured for the growing seasons in 2017 and 2018, with some soil moisture records going back to the beginning of water year 2017 (figs. 8 and 9; table 4). All north drained transects are included in figure 8, and both south drained transects and the undrained transect are included in figure 9. Some gaps in the records are evident, such as all VWC records for transect NTR2 (fig. 8), caused by a loss in data logger power that deleted these records. Other gaps were due to spikes or bad voltages that caused VWC values out of the normal ranges.

The soil would often become fully saturated for the north drained plot, particularly for transects NTR1 and NTR2 (fig. 8). For reference, the mean effective porosity for loam, 43.4 percent (0.434), is shown (Rawls and others, 1983). In general, the deeper locations (2.67 feet) at the three north drained transects had higher mean VWC over time (table 5) and the shallower locations had a greater range of VWC. For example, the mean VWC for the shallow NTR1-3 probe was 0.29 , whereas the mean VWC for the deep NTR1-3 probe was 0.38 . This contrast was clear for four out of six locations (NTR1-3, NTR1-5, NTR2-5, NTR3-5), with the other two locations close to the same mean value for shallow and deep locations. All six locations at the north drained plot had a greater range of VWC for the shallow locations than for the deeper locations. The top couple feet of soil would go through more wet and dry cycles, whereas the deeper locations were closer to the water table and therefore more saturated and in equilibrium with the water table.

The other clear difference occurred between the shallow locations near the tile in comparison to the shallow locations in the middle between the tile lines. For all three transects, the driest location was the shallow location above the tile. This dryness was likely evidence of the tile quickly draining the soil, possibly routed through well-developed macropores that could divert water towards the subsurface drain. A multiyear study of similar soil types in north-central Iowa showed evidence of macropores throughout the upper soil horizons above the subsurface drain, causing VWC to quickly spike and go back down in similar patterns (Smith, 2012; Smith and Capel, 2018).
Seasonally, no clear pattern seemed apparent, except NTR1-5 was wetter in 2017 than in 2018 (fig. 8). All VWC values were decreased in the winter months, but this condition was expected as these probes measure liquid water only- the period with frozen soils is grayed out (fig. 8). A very different pattern emerged for the 2018 growing season at the north drained plot (fig. 8). The VWC was lower overall but still showed a spiked pattern after rainfall events, often increasing and becoming fully saturated within hours of a rainfall event (fig. 10). Two examples are shown for June 2018 (fig. 10), with VWC increasing quickly after a rainfall event starting June 9 and then eventually going back down in the following days. A second example happened the same month around June 21, but because this was a smaller event VWC did not increase as much, and even a series of small rainfall events in the preceding days did not cause VWC to increase.

Similar to the north drained plot, the soil would often become fully saturated for the south drained transects (fig. 9). For reference, the mean effective porosity for loam and clay loam, 38.2 percent (0.382), is shown (Rawls and others, 1983) on the south drained transects (fig. 9) because these soils were closer to clay loam (table 4). Unlike the north drained plot, the south drained plot did not have as wide of a VWC range (table 4) and the records were less dynamic. One potential cause for this could have been fewer macropores, but another cause could have been better overall subsurface drainage across the plot. Also, with a steeper slope at the south drained plot, there was a higher likelihood of overland runoff. Nonetheless, the VWC still would often go up within hours after a rainfall event, but not as frequently or with as large of a jump as in the loam soils at the north drained plot.

The two south drained transects behaved different spatially. STR1 had similar patterns to the north drained transects, with the deeper locations (2.67 feet) having higher mean VWC over time (table 5) and the shallower locations exhibiting a wider range. STR2, on the other hand, exhibited patterns with less variability for both locations and depths. Furthermore, the deeper locations were lower over time for STR2 and the wettest location was above the tile in STR2 (STR2-5), unlike the other four drained transects.

Finally, the undrained transect exhibited the widest range in VWC, despite the two locations (SUTR1-3, SUTR1-5) only being separated by less than 40 feet. For reference, the mean effective porosity for silt loam, 48.6 percent $(0.486)$, is shown (Rawls and others, 1983). Overall, the undrained plot had fairly uniform loess only a couple feet below the land surface (table 4), so the soil would quickly drain after a rainfall event (fig. 9). One exception was that SUTR1-5 had a high overall mean VWC.

\section{Evapotranspiration}

Daily potential ET was calculated from August 27, 2016, through October 30, 2018, with most of the period shown along with precipitation from SSWS. ET played a large role 


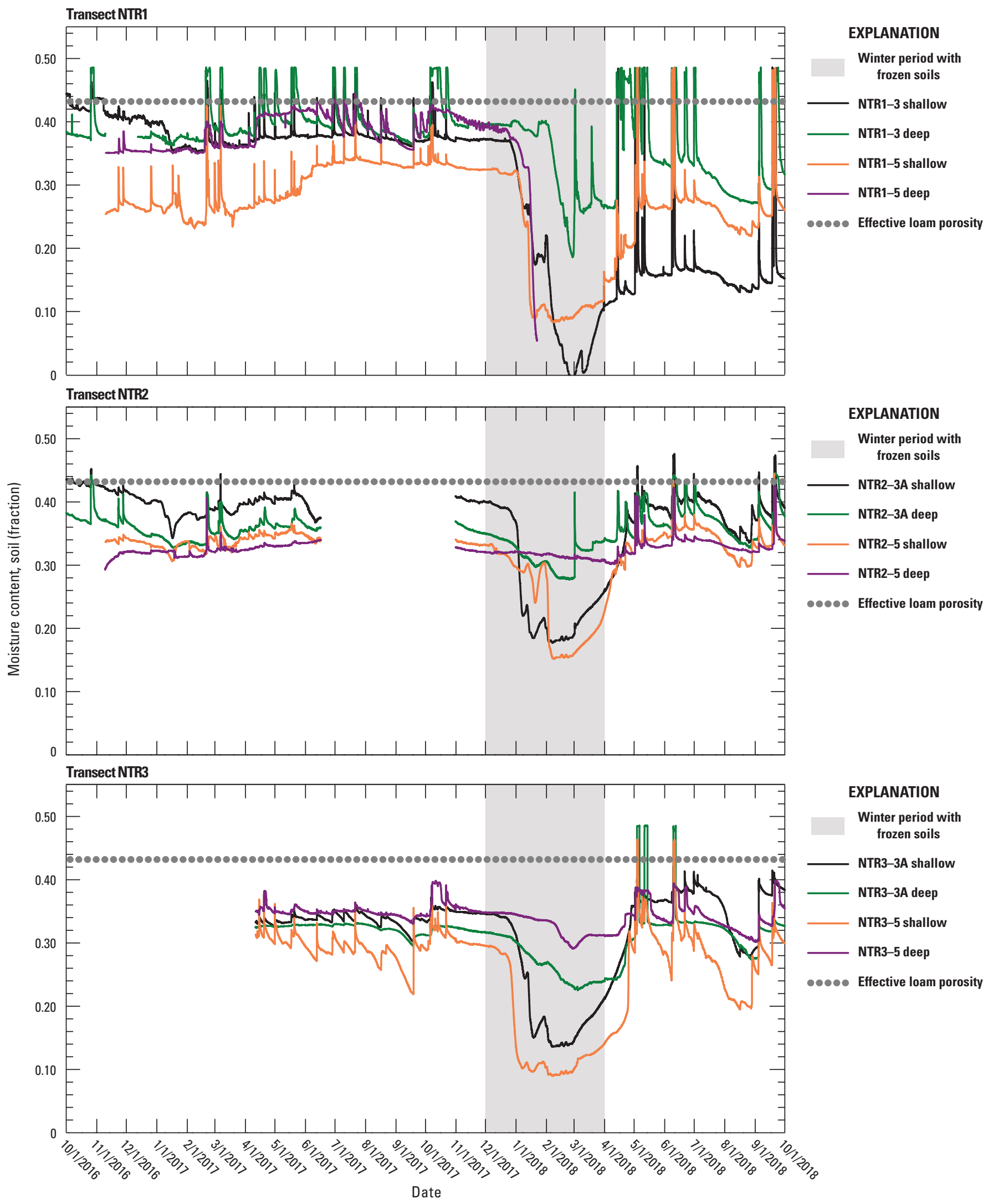

Figure 8. Volumetric water content (fraction) for the north drained transects (NTR1, NTR2, and NTR3) for October 2016 through September 2018. The mean effective porosity for loam (0.434), based on published values (Rawls and others, 1983), is shown for comparison. The winter period with frozen soils is grayed out for reference. 


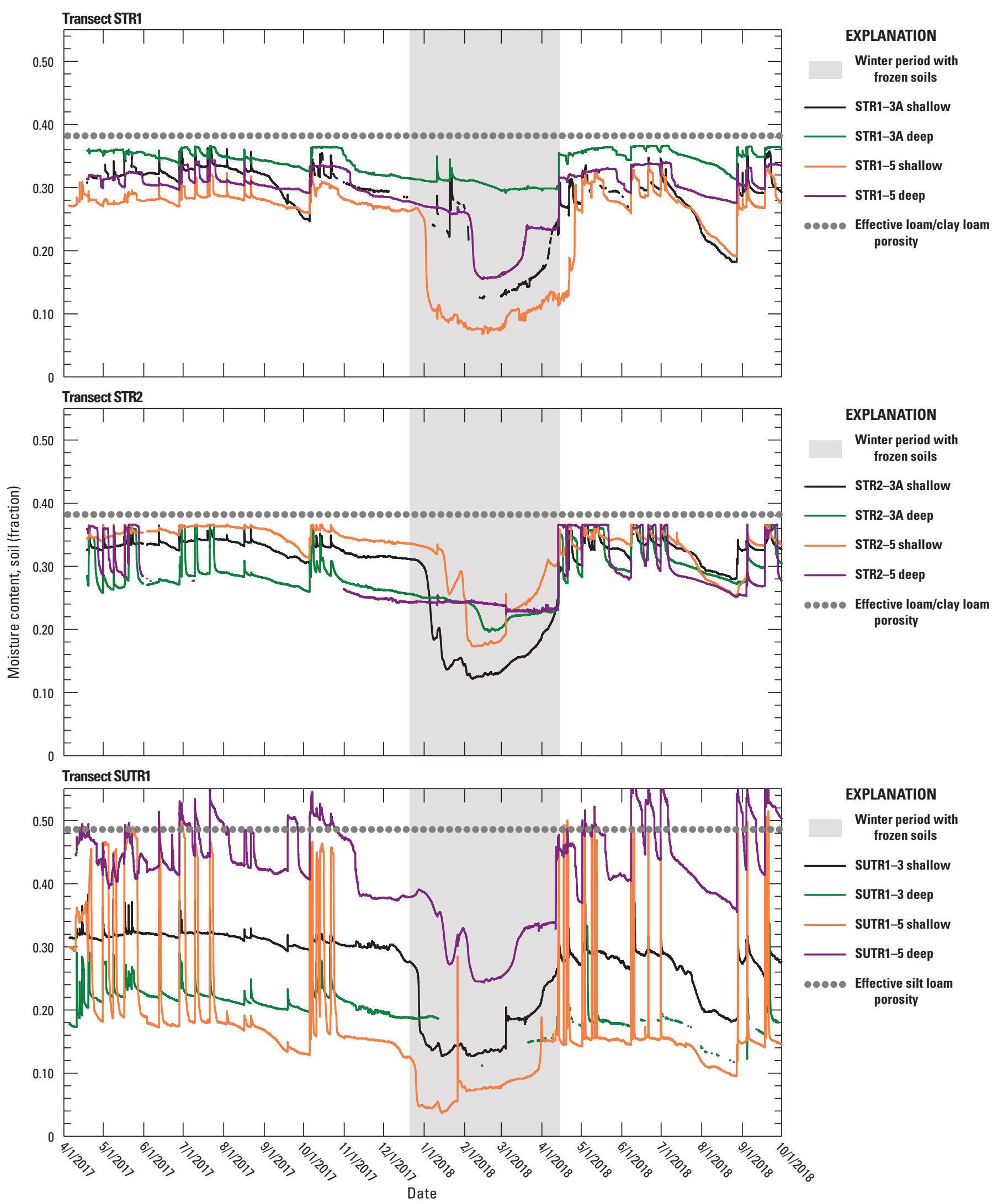

Figure 9. Volumetric water content (fraction) for the south drained transects (STR1, STR2) and the south undrained transect (SUTR1) from April 2017 through September 2018. The mean effective porosity between loam and clay loam (0.382), based on published values (Rawls and others, 1983) is shown for comparison for STR1 and STR2. The mean effective porosity for silt loam (0.486) is shown for comparison for SUTR1. The winter period with frozen soils is grayed out for reference. 
Table 5. Summary statistics, including minimum, maximum, mean, and median volumetric water content (fraction) for the north drained plot transects (NTR1, NTR2, and NTR3), south drained plot transects (STR1, STR2), and the south undrained plot (SUTR1).

[ID, identification; MID, middle between transect; ND, near drain]

\begin{tabular}{|c|c|c|c|c|c|c|c|}
\hline \multirow{2}{*}{ Site ID } & \multirow{2}{*}{ Transect } & \multirow{2}{*}{ Location } & \multirow{2}{*}{ Shallow or deep } & \multicolumn{4}{|c|}{ Volumetric water content (fraction) } \\
\hline & & & & Minimum & Maximum & Mean & Median \\
\hline \multicolumn{8}{|c|}{ North drained plot } \\
\hline NTR1-3 & NTR1 & MID & Shallow & 0.00 & 0.49 & 0.29 & 0.37 \\
\hline NTR1-3 & NTR1 & MID & Deep & 0.19 & 0.49 & 0.38 & 0.38 \\
\hline NTR1-5 & NTR1 & ND & Shallow & 0.08 & 0.49 & 0.27 & 0.27 \\
\hline NTR1-5 & NTR1 & ND & Deep & 0.05 & 0.45 & 0.38 & 0.38 \\
\hline NTR2-3A & NTR2 & MID & Shallow & 0.18 & 0.48 & 0.37 & 0.39 \\
\hline NTR2-3A & NTR2 & MID & Deep & 0.28 & 0.45 & 0.36 & 0.36 \\
\hline NTR2-5 & NTR2 & ND & Shallow & 0.15 & 0.44 & 0.32 & 0.33 \\
\hline NTR2-5 & NTR2 & ND & Deep & 0.29 & 0.43 & 0.33 & 0.32 \\
\hline NTR3-3A & NTR3 & MID & Shallow & 0.14 & 0.42 & 0.32 & 0.34 \\
\hline NTR3-3A & NTR3 & MID & Deep & 0.23 & 0.49 & 0.31 & 0.32 \\
\hline NTR3-5 & NTR3 & ND & Shallow & 0.09 & 0.46 & 0.26 & 0.29 \\
\hline NTR3-5 & NTR3 & ND & Deep & 0.29 & 0.41 & 0.34 & 0.35 \\
\hline \multicolumn{8}{|c|}{ South drained plot } \\
\hline STR1-3A & STR1 & MID & Shallow & 0.12 & 0.36 & 0.28 & 0.30 \\
\hline STR1-3A & STR1 & MID & Deep & 0.29 & 0.37 & 0.34 & 0.35 \\
\hline STR1-5 & STR1 & ND & Shallow & 0.07 & 0.34 & 0.24 & 0.27 \\
\hline STR1-5 & STR1 & ND & Deep & 0.16 & 0.34 & 0.29 & 0.30 \\
\hline STR2-3A & STR2 & MID & Shallow & 0.12 & 0.37 & 0.30 & 0.33 \\
\hline STR2-3A & STR2 & MID & Deep & 0.20 & 0.37 & 0.28 & 0.28 \\
\hline STR2-5 & STR2 & ND & Shallow & 0.17 & 0.37 & 0.32 & 0.34 \\
\hline STR2-5 & STR2 & ND & Deep & 0.22 & 0.37 & 0.29 & 0.27 \\
\hline \multicolumn{8}{|c|}{ South undrained plot } \\
\hline SUTR1-3 & SUTR1 & MID & Shallow & 0.13 & 0.38 & 0.27 & 0.29 \\
\hline SUTR1-3 & SUTR1 & MID & Deep & 0.11 & 0.34 & 0.21 & 0.21 \\
\hline SUTR1-5 & SUTR1 & ND & Shallow & 0.04 & 0.52 & 0.17 & 0.15 \\
\hline SUTR1-5 & SUTR1 & ND & Deep & 0.24 & 0.58 & 0.42 & 0.43 \\
\hline
\end{tabular}

1Each soil moisture station included two depths: 1.33 feet (shallow) and 2.67 feet (deep).

in the water budgets. The potential evapotranspiration $\left(\mathrm{ET}_{0}\right)$ rates were similar for both fields because of their proximity, as shown for an example period from June 1 to October 1, 2018 (fig. 11). For the north drained plot, the $\mathrm{ET}_{0}$ for water year 2017 (October 1, 2016, to September 30, 2017) was 46.8 inches. The $\mathrm{ET}_{0}$ for water year 2018 (October 1, 2017, to September 30, 2018) was 44.8 inches. For both years, June and July had the highest monthly $\mathrm{ET}_{0}$, with daily rates as high as 0.41 inch per day. The $\mathrm{ET}_{0}$ for the 2017 and 2018 growing seasons (May through September) was 32.9 and 31.5 inches, respectively. The daily $\mathrm{ET}_{0}$ rates, as calculated through equation 1, are included the DRAINMOD model archive (Smith, 2020a).

\section{Water-Table Surface Elevations}

Continuous water-table surface record levels were collected for 41 piezometers (water-level sites) between the three monitoring plots. The primary objective for the continuous piezometer records was to understand the water-table pattern within the subsurface drain capture zones and the water table beyond the influence of the subsurface drainage, and to collect data for potential recharge modeling. 

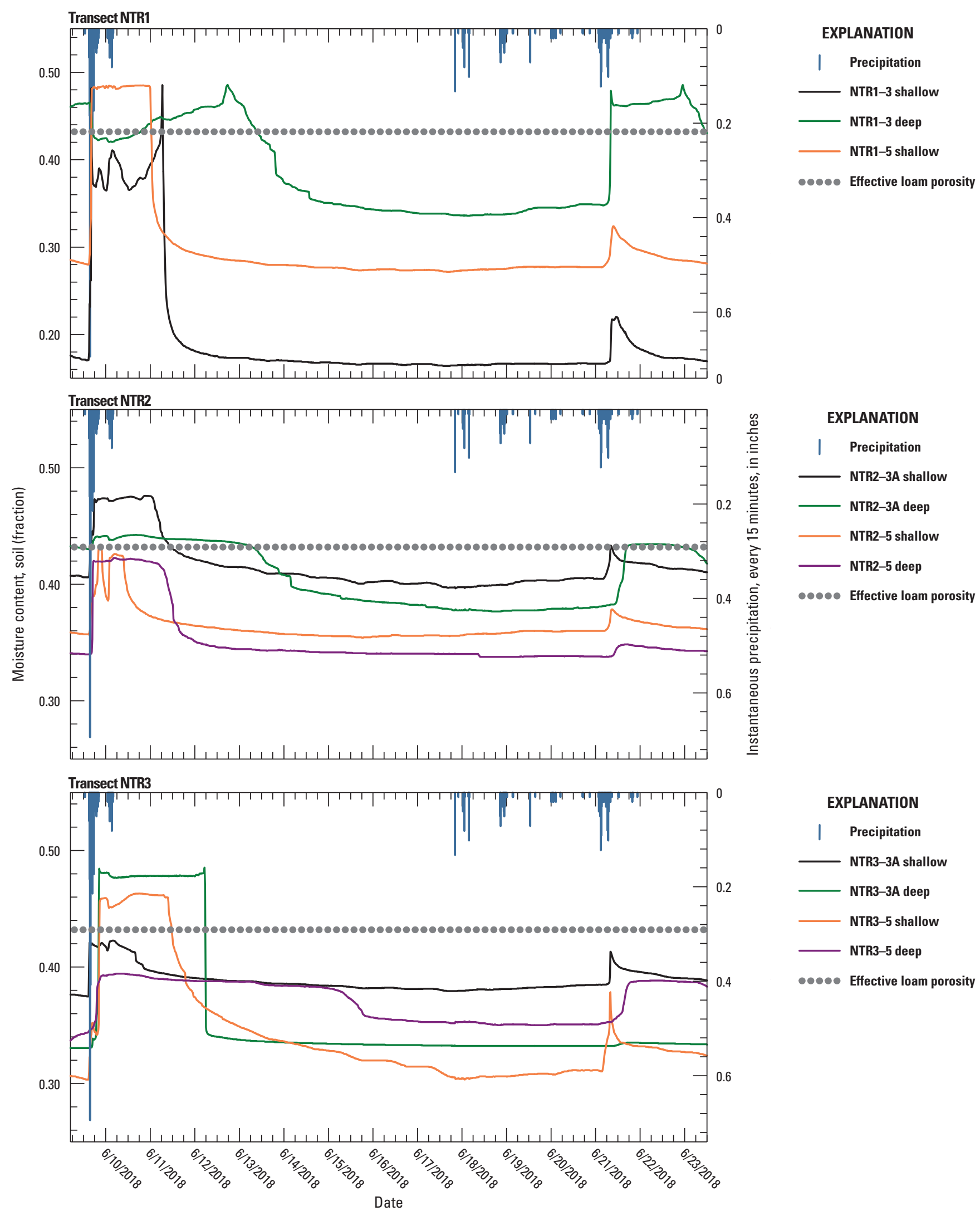

Figure 10. Volumetric water content (fraction) for the north drained transects (NTR1, NTR2, NTR3), from June 9 through June 23, 2018. The mean effective porosity between loam (0.434), based on published values (Rawls and others, 1983), is shown for comparison. 


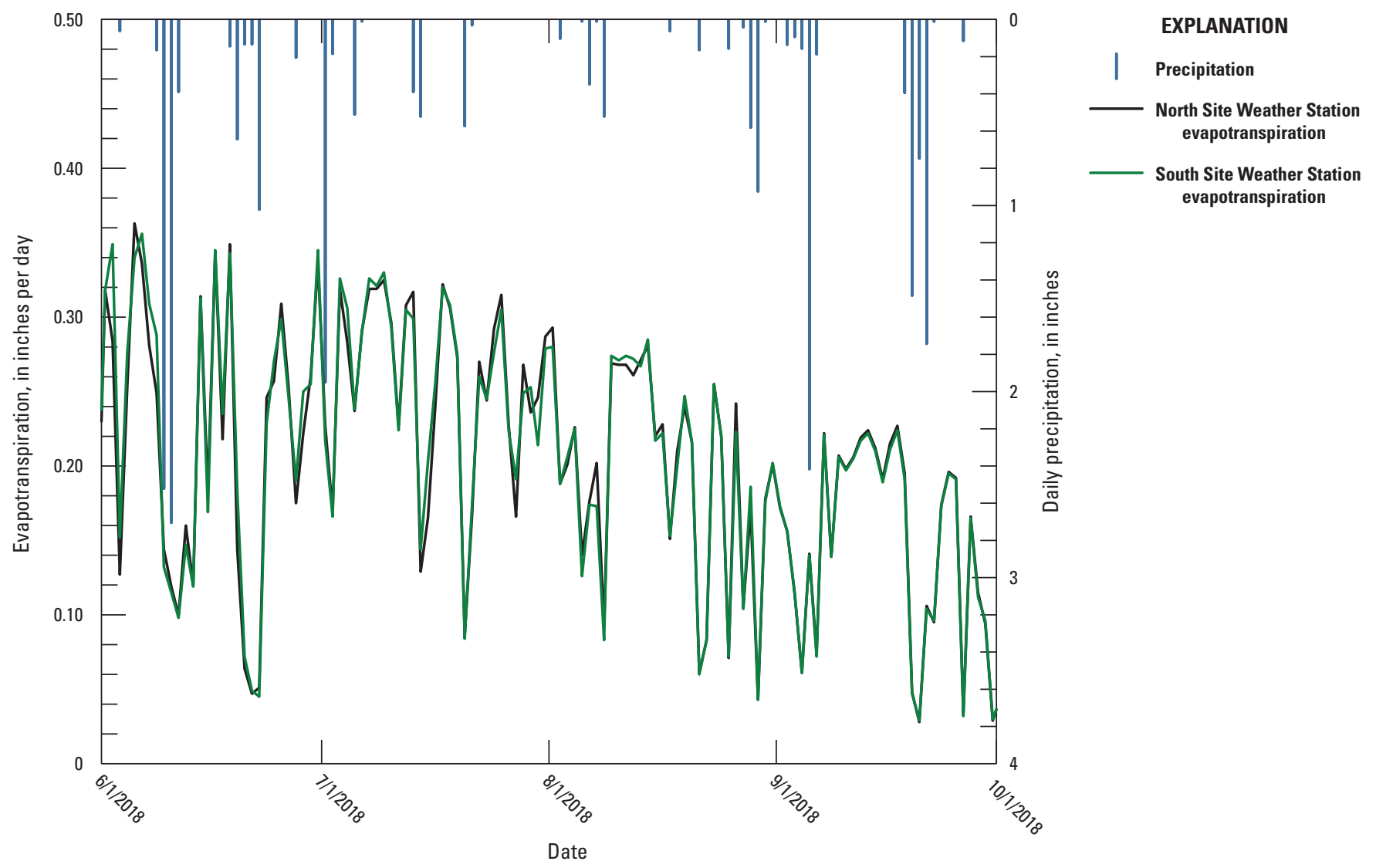

Figure 11. Potential evapotranspiration for both farmsteads, calculated from the meteorological data at North Site Weather Station (NSWS) and South Site Weather Station (SSWS) from June 1 to October 1, 2018. Also shown is the daily precipitation (in inches) from the SSWS.

\section{North Drained Plot}

The north drained transects exhibited variable watertable surface elevation patterns, depending on distance away from the drainage outfall (fig. 12). NTR1, closest to the outfall, experienced the most frequent water-level rises likely because the subsurface drainage would often back up into the field. Evidence for drainage slowdowns could be found from an indirect water-level record for the ditch: the piezometer NPR -4 was adjacent to the ditch and when the NPR-4 watertable surface level would rise, the NTR1 transect water-table surfaces would also rise (fig. 12). Upon visual inspection, water levels in NPR-4 were high when the water level in the ditch was correspondingly high. The water backup caused by the elevated ditch levels would slow down or stop drainage through the main collector drain and cause pipe pressurization, leading to water flow resistance through the unsaturated zone. This mechanism for water-table rises in agricultural fields with subsurface drains was also present in a 2-year field study from France (Henine and others, 2010) in addition to a 3-year study from north-central Iowa (Smith, 2012). In addition to pipe pressurization, the NTR1 transect sits near the bottom of the field, so natural drainage from upslope would also likely accumulate at NTR1 (figs. 2 and 12). Finally, the NTR1 transect water table surface is above the tile drain depth at this transect for most of the record. Altogether, all NTR1 piezometers with continuous water-level records did not show major differences compared to each other over time.

Transect NTR3, located between the sixth and seventh parallel tile drains going south to the end of the tile array, sat higher in the field relative to NTR1; however, NTR3 had the lowest water-table surfaces relative to the tile drain depth at this transect (fig. 12). Unlike the NTR1 pattern that was largely influenced by pipe pressurization, the water-table surface at NTR3 seemed to mostly be influenced by a combination of seasonal cycles (for example, precipitation and ET patterns) and natural groundwater drainage moving from upgradient towards the ditch. NPR-2, similar to NPR-4, was largely influenced by the ditch water level but clearly did not show the same influence on the NTR3 transect. NPR-1, which sits even higher in the field relative to the NTR3 transect, shows the same relative rise and fall patterns, displaying the connection across the field with a natural gradient of water flowing from high to low. In the spring, with the beginning of snowmelt and spring rain, the water table would rise above the level of the tile drain in 2017 and 2018 (fig. 12). Subsequently throughout the summer, the water table would 


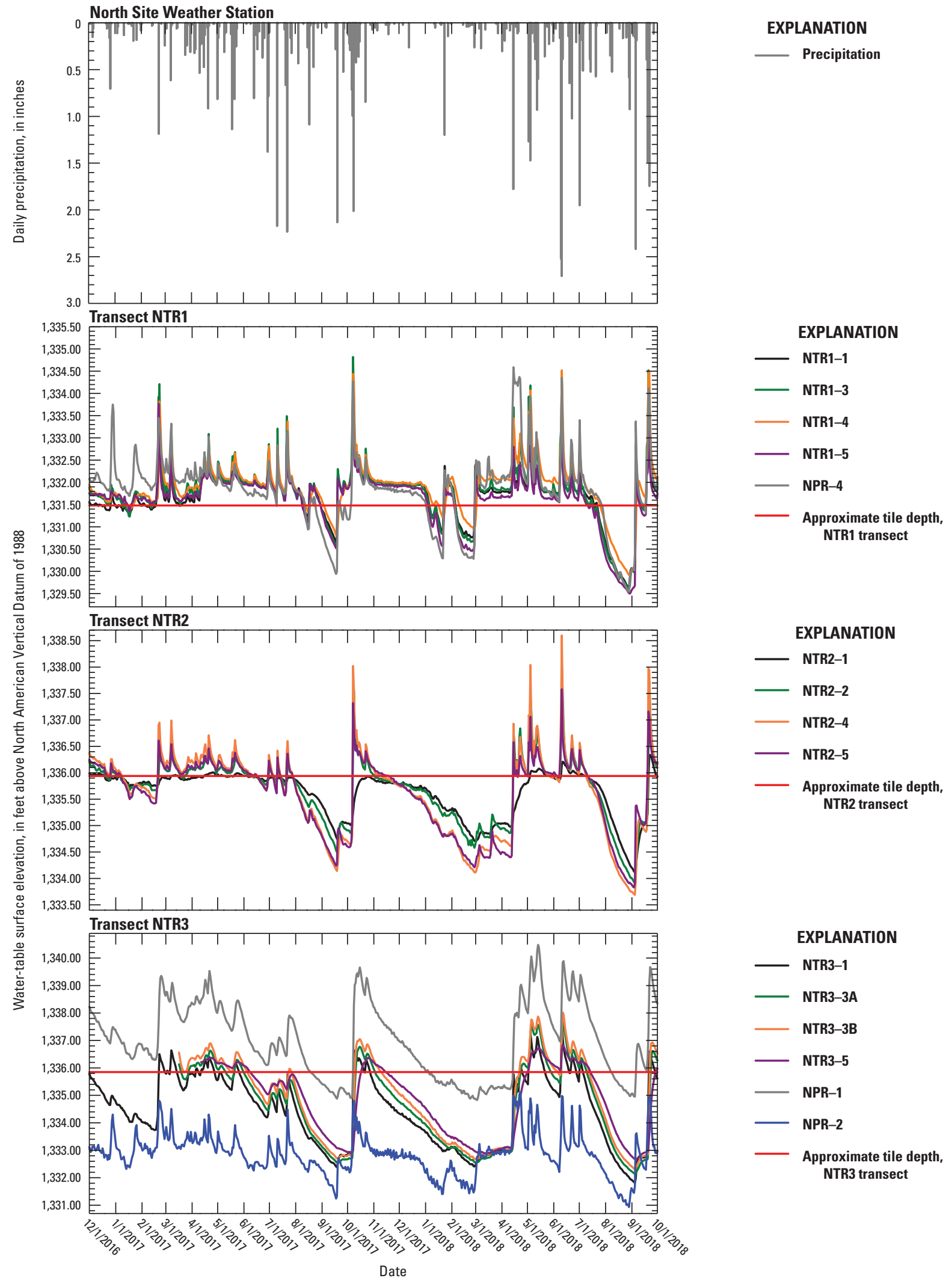

Figure 12. Water-table surface elevations for the three north drained transects (NTR1, NTR2, and NTR3) from December 2016 through September 2018. Also shown along with the transects are perimeter piezometer records for NPR-1, NPR-2, and NPR-4. Also shown for comparison is the daily precipitation total, in inches, for the North Site Weather Station (NSWS). 
slightly rise after larger rainfall events, but without the spikes in NTR1, and then the water would drain back to near the level of the subsurface drain approximately 3.5 feet below land surface. Because the influence of ET was highest during summer months, the water table reached low levels by the end of September in both years (fig. 11). With lower ET in the fall owing to less demand from the crops, the water table rose in 2017 and 2018 along with the higher precipitation during the fall (fig. 12).

The pattern of the NTR2 transect still exhibited pipe pressurization influence, but not as much as transect NTR1 (fig. 12). Water-table surface elevations seemed to follow more of a seasonal progression similar to NTR3 but experienced some temporary rises similar to NTR1 after ditch levels rose. Also, similar to NTR3, there is likely some natural groundwater drainage for NTR2, relative to NTR1, because NTR2 is upgradient from the NTR1 transect. Across all three transects, one expectation for the water-table pattern was that the watertable surface between the parallel drains would be higher over time the closer the piezometer was to the middle. This phenomenon was consistently determined for a similar study in north-central Iowa (Smith, 2012) and was first explained in detail by Hooghoudt (1952); additionally, this concept is built into models such as the DRAINMOD model (Skaggs, 1980). Infiltrating water from the land surface has a shorter lateral distance to reach the subsurface drain; however, for this study, the pattern was not clear, perhaps because differences in water levels were too subtle or the pipe pressurization effects were too high.

\section{South Drained Plot}

The two south drained transects did exhibit the expected pattern of lower water levels closer to the drain (fig. 13), although STR1 showed the best pattern because it was farther upslope (fig. 3). STR1-1, and STR1-5, and STR2-1, all located within a couple feet of the parallel drain, showed the lowest water-table surface elevations over time. STR2-1, in particular, rarely had a water-table surface elevation above the tile drain level (fig. 13). STR1-2, STR1-3A, and STR2-3A, located farther away from the subsurface drain, generally rose to higher levels and spiked frequently with larger rainfall and snowmelt events. ET still influenced all water levels. Even water-table surfaces farther from the drain, such as the water levels at STR1-2 and STR2-3A, would drop below the subsurface drain level (approximately 3.5 feet) in both summers (fig. 13).

Similar to transects NTR2 and NTR3, a seasonal cycle was present for both south drained transects, with the lowest levels in late summer and again during the winter months. In the context of subsurface drain influence on water-table surfaces, the water table behaved as expected with lower levels near the drain with the exception of STR2-5. However, it cannot be dismissed that not only does the subsurface drain influence water-table pattern, but also local heterogeneities in the soils or the influence of piezometer installation could affect water levels. Also, because the STR1 transect is upgradient from the STR2 transect, there is likely a lateral seepage component that flows towards STR2. However, unlike the north drained site, the water levels do not remain high, so the drainage at the south drained site was possibly more effective.

\section{South Undrained Plot}

The undrained transect behaved differently from the other five drained transects. Water levels would rise quickly after rainfall events and subsequently drain out, often below the bottom of the piezometer screen (fig. 13), for all four shallow undrained plot piezometers with continuous records: SUTR1-4 (not shown), SUTR1-5, SUPR-1, SUPR-2, and SUPR-4. Unlike the pattern of the two drained plots, the loess present throughout the undrained plots (table 4) had a higher vertical hydraulic conductivity that allowed water to efficiently drain from the land surface without the assistance of subsurface drains.

\section{Subsurface Drainage Flow}

Subsurface drainage flow rates and daily totals were calculated, based on equations 2 and 3, for both NSAD and SSAD (fig. 14; table 6). As mentioned in the "Methods" section, the stage discharge relation was used rather than the AV module discharge rates. Overall, the north drained plot had more overall drainage throughout the entire record, almost double the amount of total subsurface drainage flow from the south drained plot (table 6). The north drained plot had approximately 55 inches drained from the total area (approximately 6.3 acres) as opposed to approximately 24.5 inches from the south drained area (approximately 7.3 acres) (table 6). When comparing the total amount of water from precipitation, the north drained plot had less total precipitation volume than the south drained plot: 62.63 inches as opposed to 66.88 inches.

An issue with the total subsurface drainage derived for the north drained plot was when considering the ratio of subsurface drainage flow to total precipitation. For the entire period, the ratio between drainage and total precipitation was 0.88 , well above a realistic value for southeastern Minnesota, whereas the monthly ratios were often much higher. Certainly, it was possible that more drainage than precipitation could have happened for a particular month, particularly with snowmelt; however, ratios consistently above 1 were highly suspect. For a typical water budget for southeastern Minnesota, the mean ratio between ET and precipitation alone is between 0.80 and 0.90 based on figure 1 from McDonald (1961); therefore, a ratio of 0.88 for the drainage flow would indicate there was little ET. Although it has been determined that subsurface drainage does likely take water away from ET, this seemed too high. For example, a 2-year study from Wisconsin determined drainage rates of 0.41 to 0.57 for a chisel-plowed field (Brye and others, 2000). The most likely cause for the high ratio for 


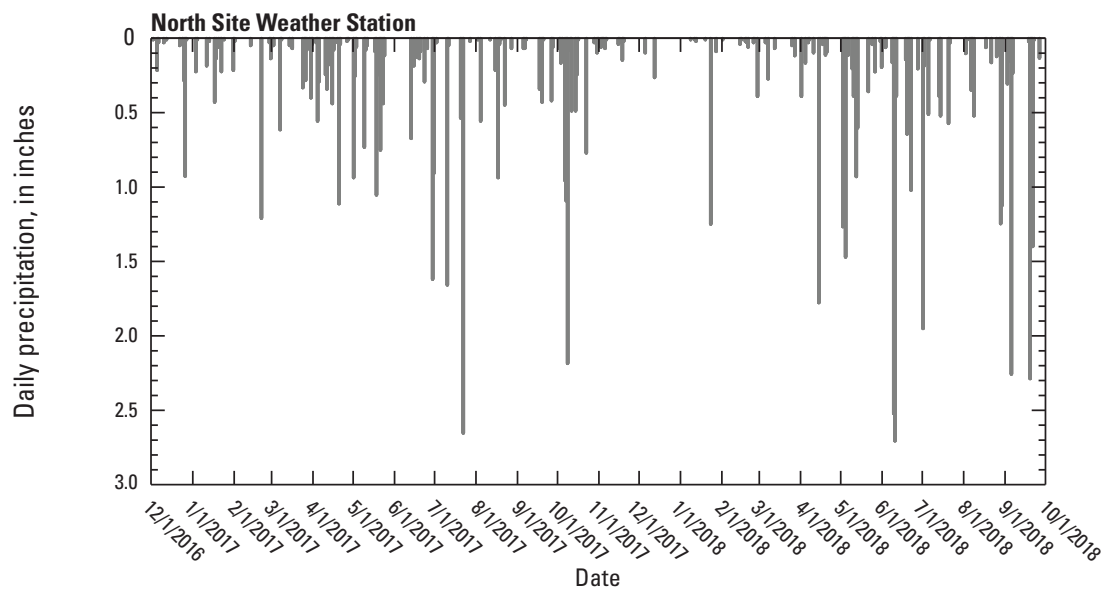

EXPLANATION

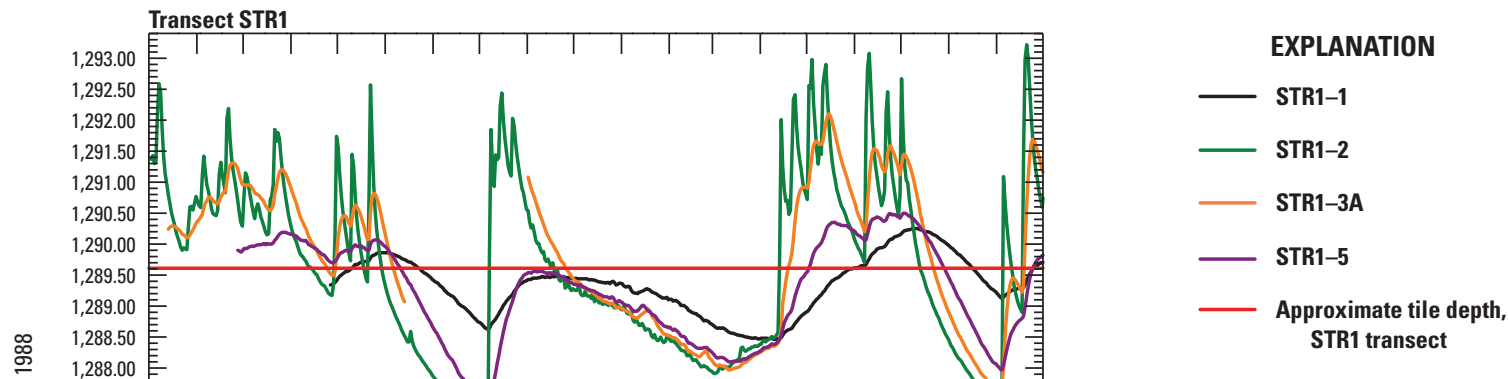

EXPLANATION

STR2-1

STR2-3A

STR2-5

Approximate tile depth, STR2 transect

EXPLANATION

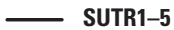

SUPR-1

SUPR-2

SUPR-4

Figure 13. Water-table surface elevations for the two drained transects (STR1 and STR2) and the one undrained transect (SUTR1) at the south farmstead from March 2017 through September 2018. Also shown along with the transects are perimeter piezometer records for SUPR-1, SUPR-2, and SUPR-4. Also shown for comparison is the daily precipitation total, in inches, for the North Site Weather Station (SSWS). 
Table 6. Total subsurface drainage flow and precipitation, by month, from April 2017 through 0ctober 2018. Total precipitation is based on the sum of daily meteorological station precipitation extrapolated across the total surface area of individual study site.

$[--$, no record $]$

\begin{tabular}{|c|c|c|c|c|c|c|}
\hline \multirow{2}{*}{ Date } & \multicolumn{2}{|c|}{$\begin{array}{l}\text { Total subsurface drainage flow, } \\
\text { in inches }\end{array}$} & \multicolumn{2}{|c|}{ Total precipitation, in inches } & \multicolumn{2}{|c|}{$\begin{array}{l}\text { Ratio of subsurface drainage to } \\
\text { total precipitation, in percent }\end{array}$} \\
\hline & $\begin{array}{l}\text { North drained } \\
\text { site }\end{array}$ & $\begin{array}{l}\text { South drained } \\
\text { site }\end{array}$ & $\begin{array}{l}\text { North drained } \\
\text { site }^{1} \\
\end{array}$ & $\begin{array}{c}\text { South drained } \\
\text { site }^{2}\end{array}$ & $\begin{array}{l}\text { North drained } \\
\text { site }\end{array}$ & $\begin{array}{l}\text { South drained } \\
\text { site }\end{array}$ \\
\hline April 2017 & 3.57 & 1.45 & 1.85 & 1.97 & 1.93 & 0.73 \\
\hline May 2017 & 3.50 & 1.79 & 4.09 & 4.84 & 0.85 & 0.37 \\
\hline June 2017 & 1.52 & 0.50 & 4.09 & 4.18 & 0.37 & 0.12 \\
\hline July 2017 & 2.95 & 1.66 & 5.73 & 4.99 & 0.51 & 0.33 \\
\hline August 2017 & 0.23 & 0.00 & 2.36 & 2.31 & 0.10 & 0.00 \\
\hline September 2017 & 1.04 & 0.00 & 3.09 & 1.42 & 0.34 & 0.00 \\
\hline October 2017 & 7.36 & 1.30 & 6.53 & 6.87 & 1.13 & 0.19 \\
\hline November 2017 & 1.15 & 0.13 & 0.35 & 0.40 & 3.27 & 0.31 \\
\hline December 2017 & 0.64 & 0.00 & 0.28 & 0.36 & 2.27 & 0.00 \\
\hline January 2018 & 2.37 & 0.40 & 1.45 & 1.40 & 1.64 & 0.29 \\
\hline February 2018 & 1.20 & 0.00 & 0.45 & 0.60 & 2.64 & 0.00 \\
\hline March 2018 & 2.90 & 0.00 & 0.82 & 0.93 & 3.52 & 0.00 \\
\hline April 2018 & 5.46 & 2.05 & 2.40 & 2.37 & 2.27 & 0.86 \\
\hline May 2018 & 7.98 & 4.10 & 6.43 & 6.48 & 1.24 & 0.63 \\
\hline June 2018 & 7.97 & 4.02 & 9.72 & 9.78 & 0.82 & 0.41 \\
\hline July 2018 & 2.10 & 0.60 & 2.56 & 2.58 & 0.82 & 0.23 \\
\hline August 2018 & 0.00 & 0.00 & 2.94 & 3.78 & 0.00 & 0.00 \\
\hline September 2018 & 3.11 & 2.82 & 7.48 & 7.70 & 0.42 & 0.37 \\
\hline October 2018 & -- & 3.67 & -- & 3.91 & -- & 0.94 \\
\hline Total & 55.04 & 24.48 & 62.63 & 66.88 & 0.88 & 0.37 \\
\hline
\end{tabular}

${ }^{1}$ Total precipitation based on daily North Site Weather Station precipitation extrapolated across 6.263 acres.

${ }^{2}$ Total precipitation based on daily South Site Weather Station precipitation extrapolated across 7.338 acres.

this study was that the subsurface drainage flow was overestimated. Water frequently backed up into the subsurface drain from the adjacent drainage ditch, thereby limiting or completely stopping the drainage flow. In such cases, the water-level height in the Agri Drain would have been higher than if it was flowing unimpeded, which would create an artificially high drainage flow rate. Aside from water backing up, the calculated area of drainage could have also been in error (for example, if the drainage flow was captured from a much larger area). The assumed area was only an estimate, based on distance from the lines assumed to be a part of the parallel drains, and it was possible the area was too small or other parallel lines existed.

For the south drained plot, the ratio for the entire period between subsurface drainage flow and precipitation was 0.37 (table 6), a more realistic value, particularly in consideration of the Wisconsin study (Brye and others, 2000). Although this ratio was still high given that the overall ET rate would have to be lower, other water-budget components such as surface runoff, lateral flow, and potential groundwater recharge could have also been lower in magnitude to compensate. Also, the monthly ratios were highest in the spring (April, May) when snowmelt would have likely been an additional source of water.

To compare the two different records, figure 14 was useful for examining the relative subsurface drainage patterns, even if the NSAD record was problematic. Both plots showed similar drainage patterns, not unexpected given the similar field sizes, drain spacing (approximately 80 feet), and proximity to each other (within 4 miles), although the two fields were reversed for cropping history in that one field had soybeans when the other field had corn. Subsurface drainage showed a fast increase after any substantial precipitation event (precipitation above 0.5 inch), generally within hours. Similar to the ratios of subsurface drainage flow to precipitation, the long periods of continuous subsurface drainage for NSAD were likely exaggerated considering there would often be no SSAD flow at the same time. 


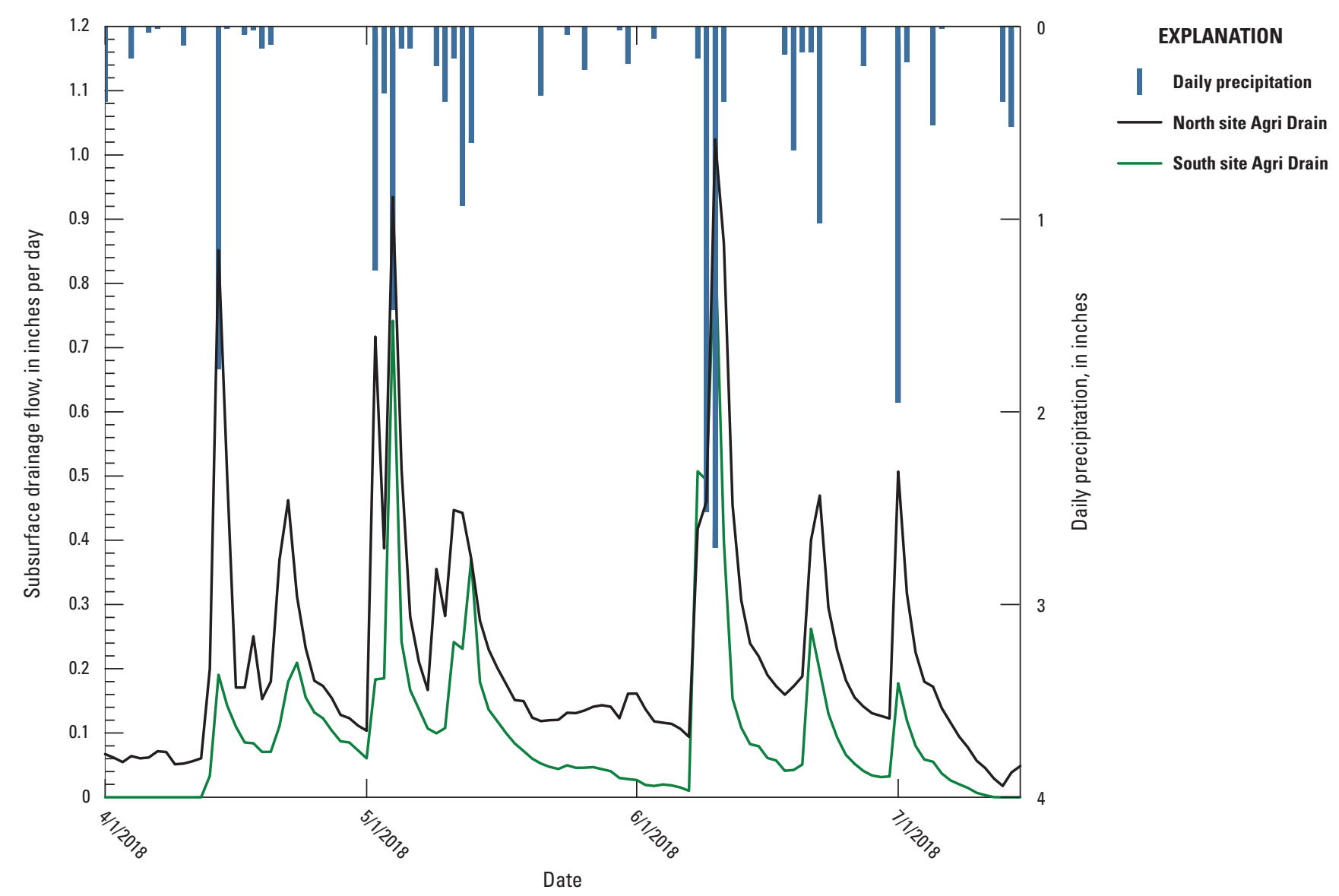

Figure 14. Total subsurface drainage flow, in inches per day, for the North Site Agri Drain (NSAD) and the South Site Agri Drain (SSAD) from April 1 to July 15, 2018. Also shown is the daily precipitation total, in inches, for the South Site Weather Station.

\section{Potential Groundwater Recharge Rates}

Three methods were used to derive potential groundwater recharge rates: the RISE WTF method, the SWB model, and the DRAINMOD model. The first two methods, the RISE WTF method and the SWB model, approximate the amount of recharge to the water table closest to land surface. For both farmsteads, a restricting layer separates the perched water table above from the bedrock aquifer below the restricting layer. For the third method, the DRAINMOD model, the deep seepage rates were assumed to be equal to the potential groundwater recharge to the bedrock aquifer below the restricting layer. For this study, potential groundwater recharge was defined as infiltrating water that passed below the unsaturated zone and the subsurface drain capture zone. Because the first two methods only approximate to the top of the watertable surface, there is a fundamental difference between the first two methods and the third method.

\section{Potential Recharge-RISE Water-Table Fluctuation and Soil-Water-Balance Estimates}

Recharge was estimated from the continuous hydrographs of 37 piezometers (water-level sites) using RISE WTF (tables 7 and 8), including three piezometers with screened intervals greater than 30 feet below land surface (Smith, 2020c). Piezometers were grouped into different categories for comparison, generally listed into multiple categories as identified in tables 7-9. For all the non-deep piezometers (screened interval less than 16 feet), water year 2017 had 15 piezometers with complete records (11-12 months with monthly recharge rates) (table 7), and water year 2018 had 34 piezometers with complete records (11-12 months with monthly recharge rates) (table 8). All monthly RISE WTF groundwater recharge rates, grouped by month for both water years 2017 and 2018, are included in tables 7 and 8 .

Mean potential groundwater recharge rates across all piezometers were 1.55 and 1.94 inches per year, respectively, for water years 2017 and 2018 (table 9). The piezometers were also separated into different categories, including all piezometers, drained transect piezometers (over drain and middle between transect piezometers), all drained transect 


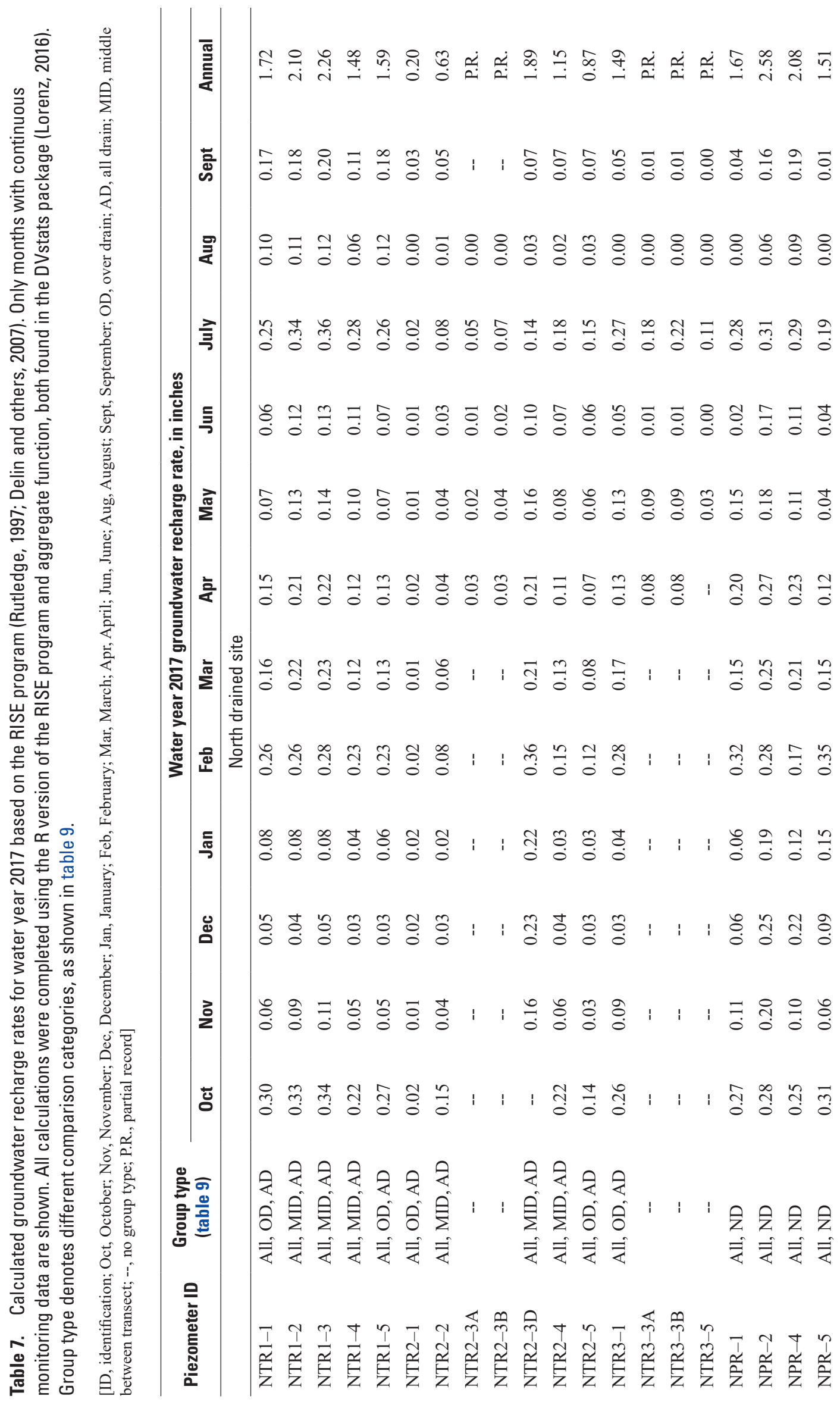




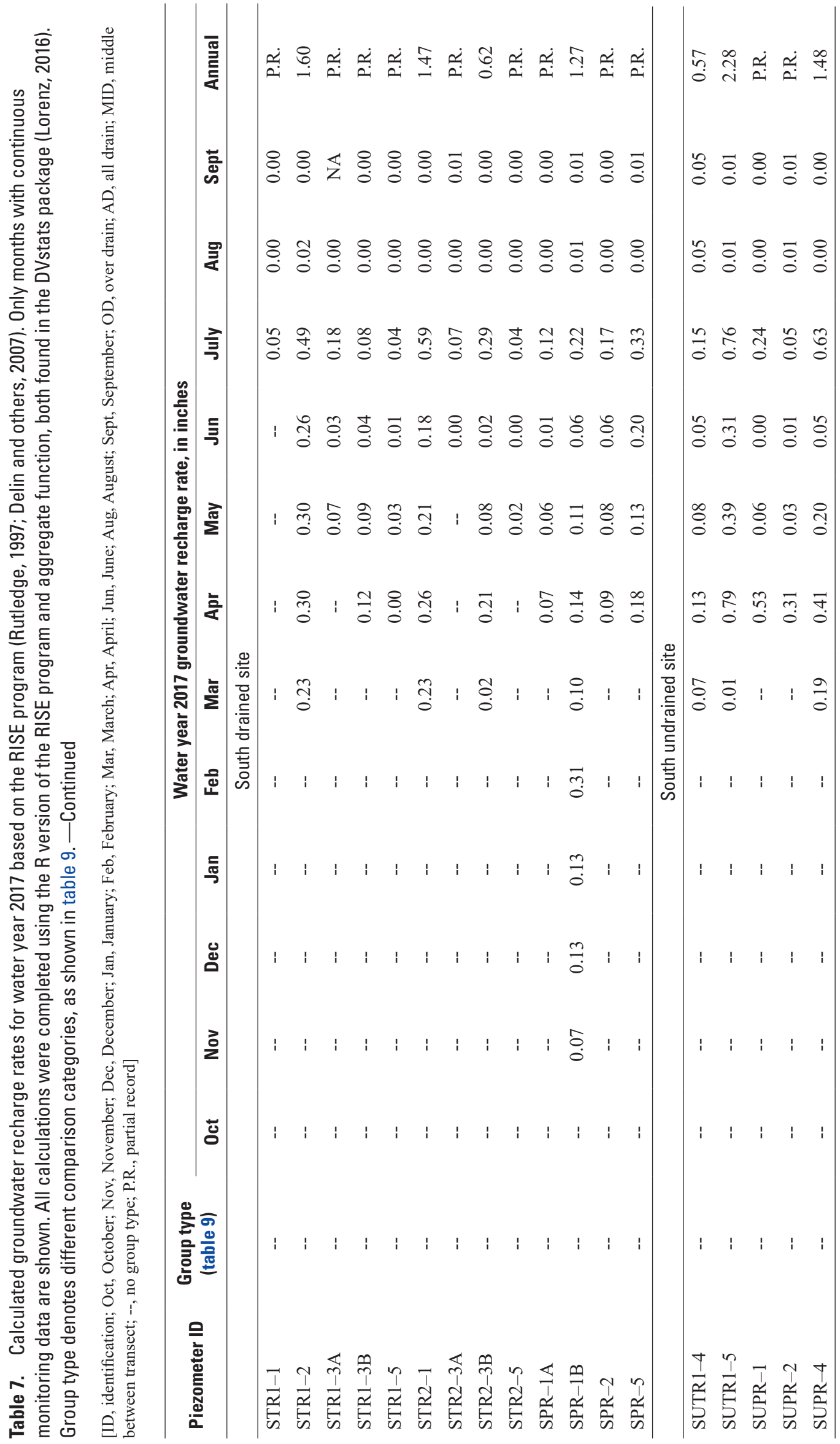




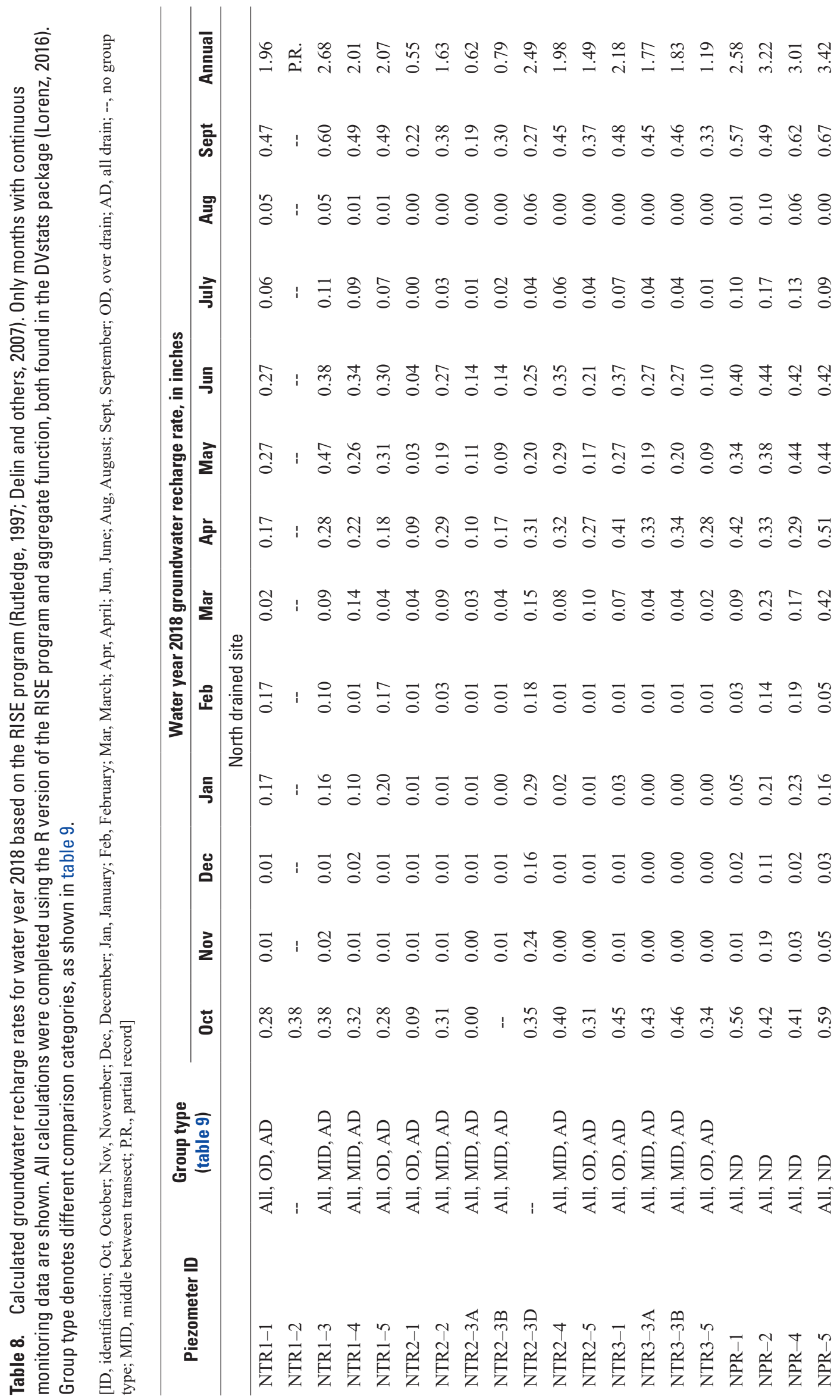




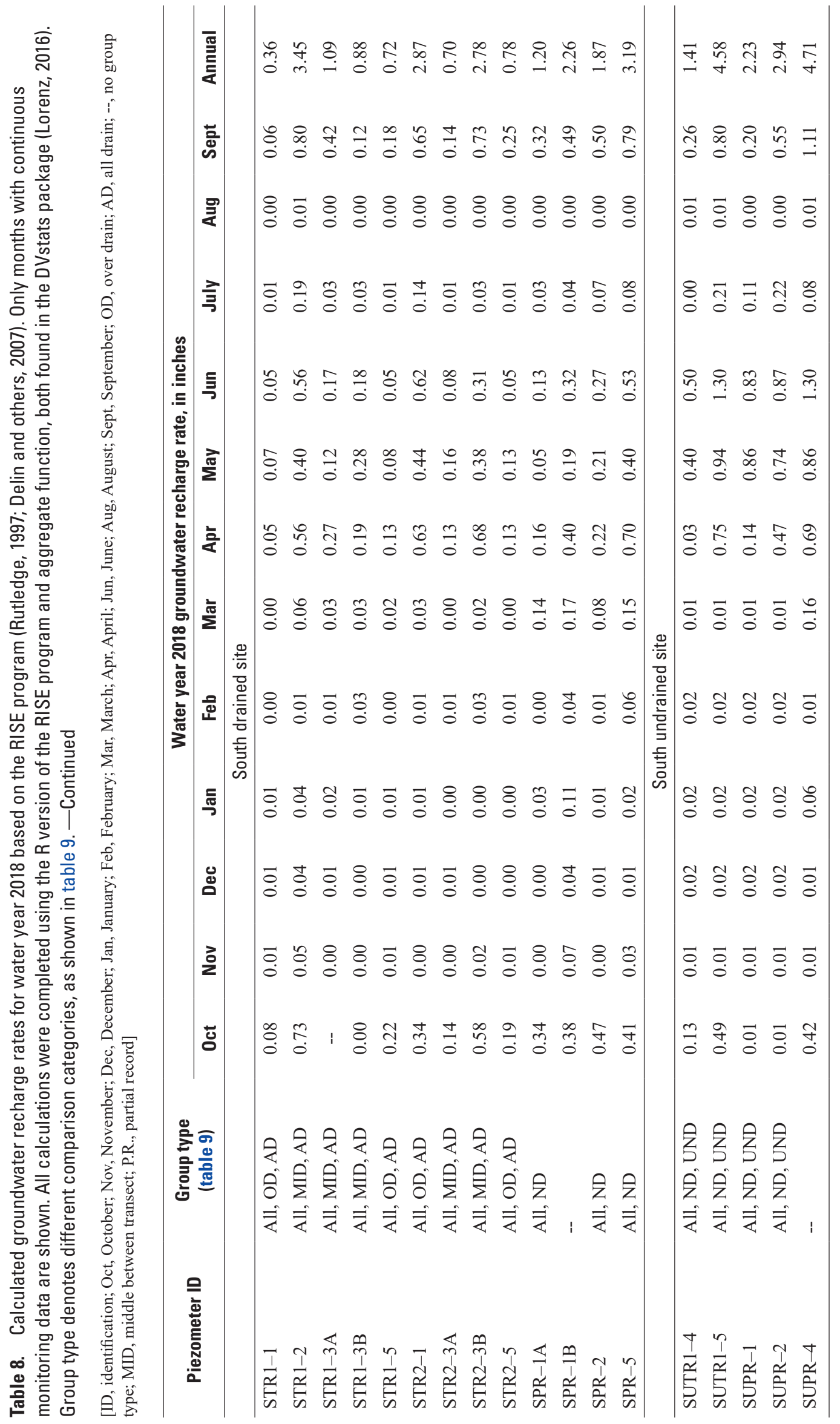


Table 9. Summary statistics, including minimum, maximum, mean, and median potential recharge (in inches) as calculated by the RISE program for water years 2017 and 2018, grouped by different categories of piezometer records. Group type category from tables 7 and 8 given in parentheses.

\begin{tabular}{|c|c|c|c|c|c|}
\hline \multirow{2}{*}{ Group type } & \multirow{2}{*}{$\begin{array}{l}\text { Number of } \\
\text { records }\end{array}$} & \multicolumn{4}{|c|}{ Potential recharge, in inches } \\
\hline & & Minimum & Maximum & Mean & Median \\
\hline \multicolumn{6}{|c|}{ Water year 2017 (October 1, 2016-September 30, 2017) } \\
\hline All piezometers (ALL) & 15 & 0.20 & 2.58 & 1.55 & 1.59 \\
\hline Drained transects: over drain (OD) & 5 & 0.20 & 1.72 & 1.17 & 1.49 \\
\hline Drained transects: middle between transect (MID) & 6 & 0.63 & 2.26 & 1.59 & 1.69 \\
\hline Drained transects: all (AD) & 11 & 0.20 & 2.26 & 1.40 & 1.49 \\
\hline Nondrained piezometers: all (ND) & 4 & 1.51 & 2.58 & 1.96 & 1.87 \\
\hline \multicolumn{6}{|c|}{ Water year 2018 (October 1, 2017-September 30, 2018) } \\
\hline All piezometers (ALL) & 34 & 0.36 & 4.58 & 1.94 & 1.91 \\
\hline Drained transects: over drain (OD) & 10 & 0.36 & 2.87 & 1.42 & 1.34 \\
\hline Drained transects: middle between transect (MID) & 13 & 0.62 & 3.45 & 1.71 & 1.77 \\
\hline Drained transects: all (AD) & 23 & 0.36 & 3.45 & 1.58 & 1.63 \\
\hline Nondrained piezometers: all (ND) & 11 & 1.20 & 4.58 & 2.70 & 2.94 \\
\hline Undrained transect only (UND) & 4 & 1.41 & 4.58 & 2.79 & 2.58 \\
\hline
\end{tabular}

piezometers, nondrained piezometers, and undrained transect piezometers. Although some of the categories had few records, such as undrained plot piezometers or most 2017 categories, table 9 was still illustrative for discussion purposes.

There were few differences between the different categories for water year 2017, although the available potential recharge rates were limited. For mean potential recharge, all categories were in a narrow range of 1.17 to 1.96 inches per year, with an even smaller range of 1.48 to 1.87 inches per year for the median values. The only category with a slightly higher mean value was the nondrained piezometers; however, a t-test assuming unequal variances between the nondrained piezometers (sample size $=4$ ) and drained piezometers (sample size $=11$ ) determined the two groups were not statistically different, with a $p$-value of $0.11(\alpha=0.05)$.

More differentiation of the categorical potential recharge rates occurred for water year 2018, with a higher mean recharge rate of 2.70 inches per year for nondrained (including undrained site) piezometers as opposed to 1.58 inches per year for all drained piezometers. Although the difference was slightly more than 1 inch between the nondrained and drained piezometers for water year 2018, this difference was statistically significant based on a t-test assuming unequal variances with a $p$-value of less than $0.01(\alpha=0.05)$. Furthermore, the undrained plot piezometers also had a higher mean value of 2.79 inches per year. Within the transects, the mean and median values were higher for the transect piezometers away from the drain; however, there were no clear differences in either water year for the two transect categories, based on t-tests. With more records available for evaluation in 2018, a t-test determined no statistical difference, with a $p$-value of 0.43 . The lack of a statistical difference seemed to indicate that distance away from the subsurface drain did not affect potential recharge, although other factors such as variability in screen depths, well construction, and specific yield variability cannot be eliminated.

The SWB model was also used to estimate potential recharge rates for water years 2017-18 (Smith, 2020b). Potential recharge across the three monitoring plots, as calculated by the SWB model, was between 2.44 and 5.92 inches per year for the two drained plots in water years 2017 and 2018. All north drained plot piezometers were captured by one 1-kilometer cell for the SWB model, except for NPR-5. At the north drained plot, SWB potential recharge was 5.66 and 2.44 inches per year, respectively, for water years 2017 and 2018; for NPR-5, the SWB potential recharge was similar with 5.53 and 2.58 inches per year, respectively, for water years 2017 and 2018. At the south drained plot, SWB potential recharge was 4.92 and 2.64 inches per year, respectively, for water years 2017 and 2018. For the undrained plot, the SWB potential recharge stood out from the drained plot at 10.26 and 17.26 inches per year, respectively, for water years 2017 and 2018 .

Overall, the RISE WTF potential recharge rates were lower than SWB rates when considering only water year 2017; however, if considering water year 2018 for both methods, the potential recharge rates were much closer for the drained plots. For the undrained plot, there was a large gap between the two methods although the available RISE WTF potential recharge estimates at the undrained plot were limited. 


\section{Potential Recharge-DRAINMOD}

DRAINMOD models were completed for a total of nine different sites (Smith, 2020a). The primary guide for parameterization and calibration was a 2012 synthesis paper that discussed appropriate calibration targets and parameter ranges for a typical DRAINMOD model (Skaggs and others, 2012). The recommendation for any period was a minimum of 2 years for calibration and 2 years for validation, although for this study, time was limited so all data were included with the calibration. Other sources for model parameterization included other DRAINMOD model simulations, in particular the example simulations included within the DRAINMOD model (Skaggs, 1980).

The full parameterization for all nine sites is included in table 10 except for the detailed soil-water characteristics that are available as part of the model archive (Smith, 2020a). All soil-water characteristics, as discussed in the "Methods" section, were derived from inferring the SSURGO soil type at the individual piezometer. In general, the variability between the different model runs was mostly whether it was a transect or perimeter site. For perimeter sites, the spacing was set at 18,000 centimeters (180 meters), with no drainage coefficient to prevent drainage from being simulated; for the transect sites, spacing varied between 2,135 and 2,440 centimeters ( 21.35 to 24.4 meters, or 70 to 80 feet) and the drainage coefficient was between 0.64 and 1.27 centimeters per day ( 0.25 to 0.50 inch per day).

Potential recharge, as derived from the deep seepage rate in the DRAINMOD model, was between 2.07 to 9.49 inches per year across the nine different sites (table 11). If grouped into two distinct categories, drained piezometers as compared to nondrained piezometers, the potential recharge rate for the transect piezometers was almost one-half ( 3.80 inches per year) of the potential recharge rate for the perimeter piezometers (7.11 inches per year). Because the transect piezometers represented drained areas and the perimeter piezometers represented nondrained areas, these DRAINMOD model scenarios also determined a distinct difference in the recharge rate for the drained areas.

For calibration, criteria from Skaggs and others (2012) for a DRAINMOD model was followed, with an NSI recommendation of at least 0.40 for an acceptable calibration and 0.75 for an excellent calibration when calibrating to daily water-table depths. For MAE, the criteria was less than 20 centimeters for a good calibration and less than 10 centimeters for an excellent calibration. All nine sites fell under this criteria, except SPR-5 with an MAE of 21.10 centimeters (table 11). Two of the nine model scenarios are shown in figure 15, illustrating the difference between an excellent calibration (STR2-2) and an acceptable calibration (NPR-4). For the acceptable calibration, the time period was shorter, the winter period was not well characterized, and several of the peaks were off, although the general water-level trends were still characterized.

\section{Potential Recharge Comparison Across Study Area}

Fundamentally, the RISE WTF and SWB results evaluate the same component of potential groundwater recharge, approximately the amount of recharge to the water table closest to land surface. Neither of these models are capable of taking tile drains into account. The SWB results could be taken as the maximum potential recharge expected, with the qualification that this recharge is for a 1-kilometer scale. The RISE WTF results, however, simulate point estimates of groundwater recharge that are influenced indirectly by the presence of tile drains. The model does not explicitly account for tile drains, but the water-table surface elevations around tile drains are affected by tile drains. For example, changes in water-level rises caused by the tile drain would influence rise classification; therefore, subdued water-table surface elevations would cause lower recharge estimates by this method.

The DRAINMOD model, however, does explicitly account for tile drains and the restricting layer between the surficial water-table surface and the aquifer below the restricting layer. In the various DRAINMOD model scenarios, approximately 25 feet of restricting layer was assumed to the aquifer below, although the study was unable to confirm this result for any of the nine sites used with the DRAINMOD model. Therefore, the deep seepage rates reported in tables 11 and 12 were assumed as the potential groundwater recharge to the aquifer below. Hence, these fundamental differences would need to be considered for any comparisons between RISE WTF method and the SWB model to the DRAINMOD model.

For the RISE WTF method and DRAINMOD model, the tile drain pressurization for the north drained site could have influenced the recharge estimates, particularly the estimates for the NTR1 transect piezometers. The pipe pressurization would have likely caused the water levels to rise more with smaller rainfall events. Therefore, because the RISE WTF estimates are partially a product of water-level rise, these estimates would have been overestimated for the drained areas and the actual recharge might have been smaller in the absence of pipe pressurization. For the DRAINMOD model, larger rises would have potentially led to the model overestimating the runoff component, also leading to smaller estimates for the deep seepage rates.

The DRAINMOD-derived potential recharge estimates and the RISE WTF results are compared in table 12 because these point estimates can be made to a specific location. For six of the 12 possible comparisons, looking at both years, the difference between the two methods was less than 1 inch per year (table 12). The other six possible comparisons had a much wider range, with the DRAINMOD model estimating more potential recharge by as much as 7.62 inches per year; in all six models with larger gaps, the DRAINMOD model estimated more recharge.

Overall, there was a lack of agreement between the three methods, even when comparisons were made with an individual piezometer using the RISE WTF and DRAINMOD 


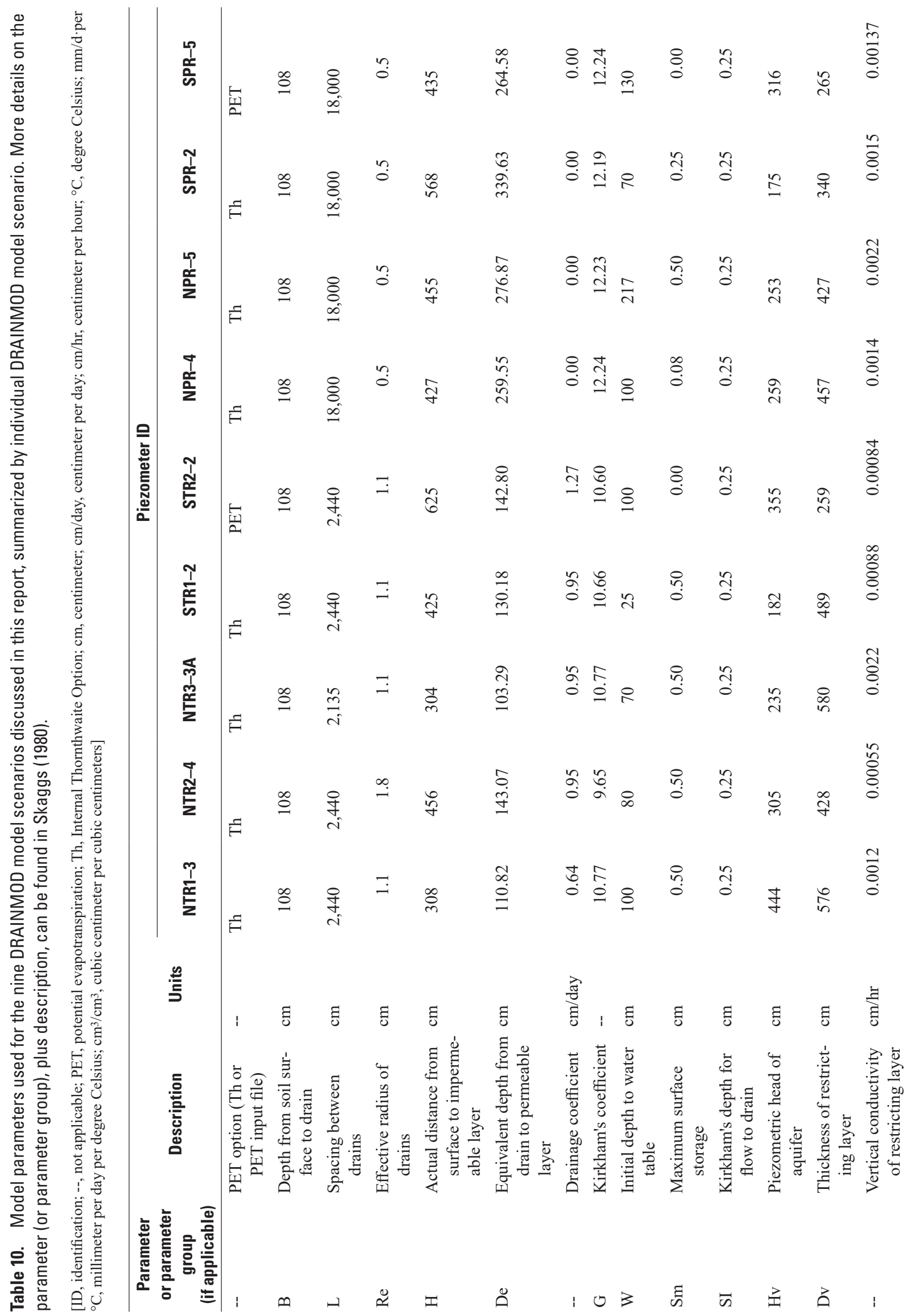




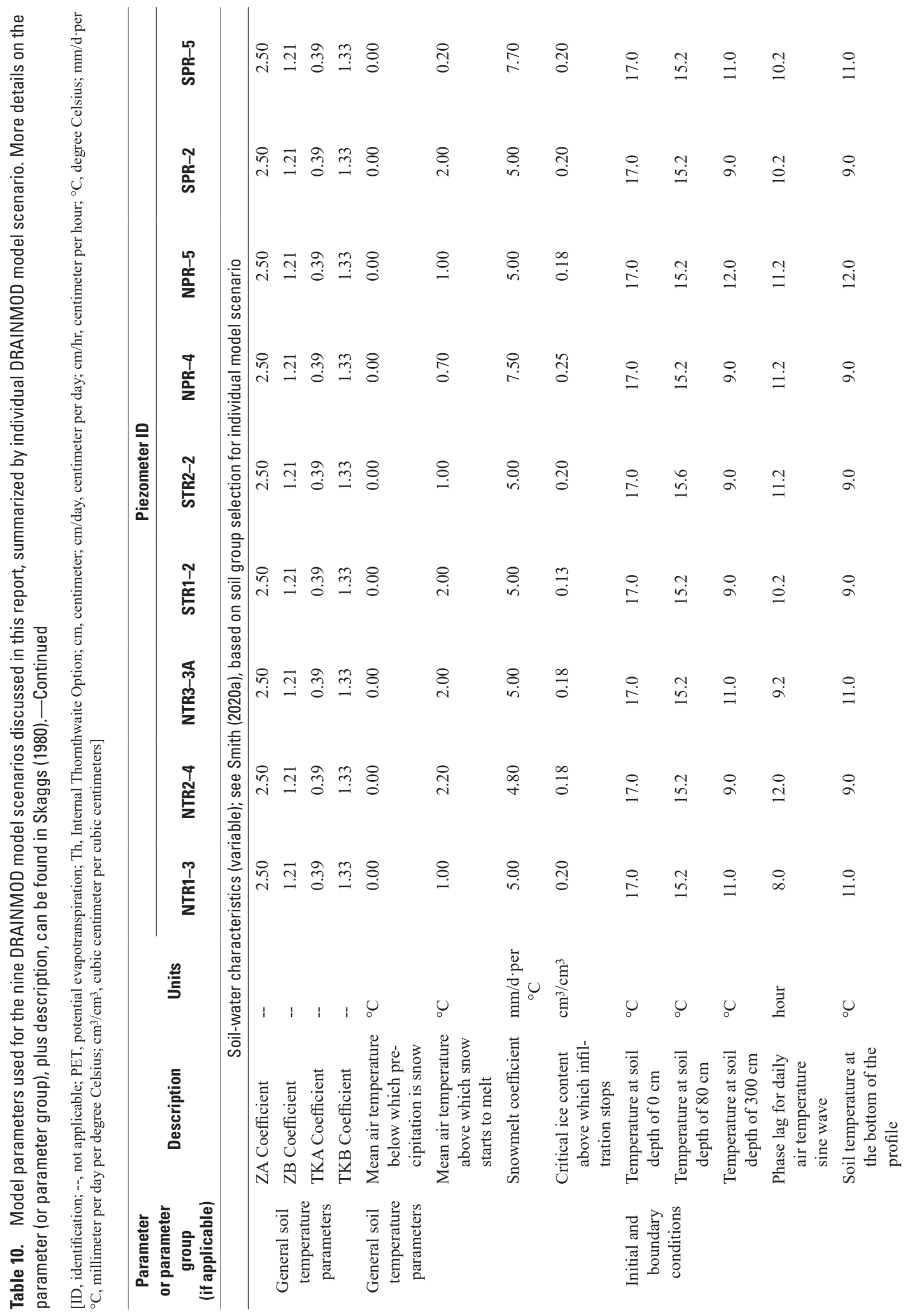




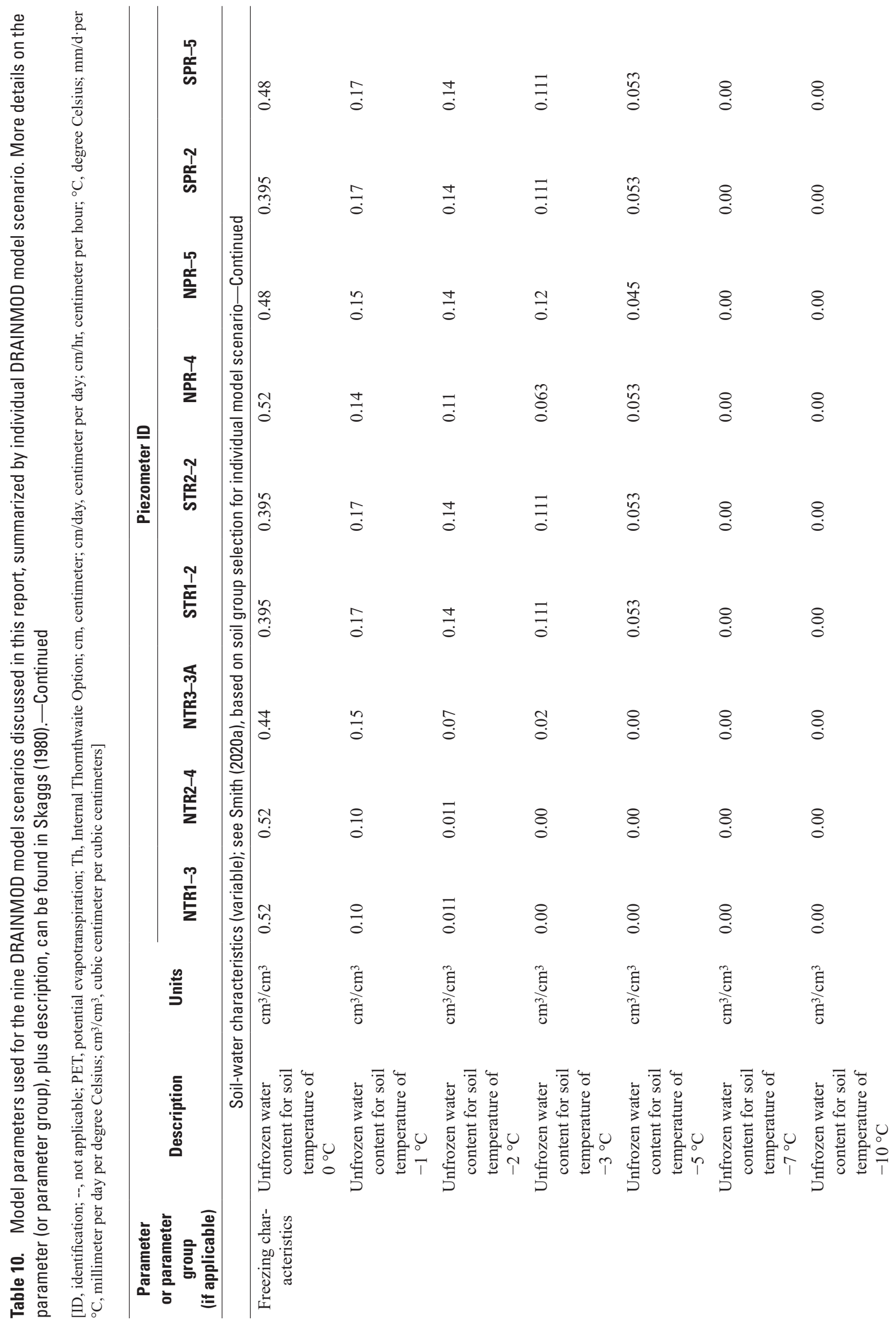




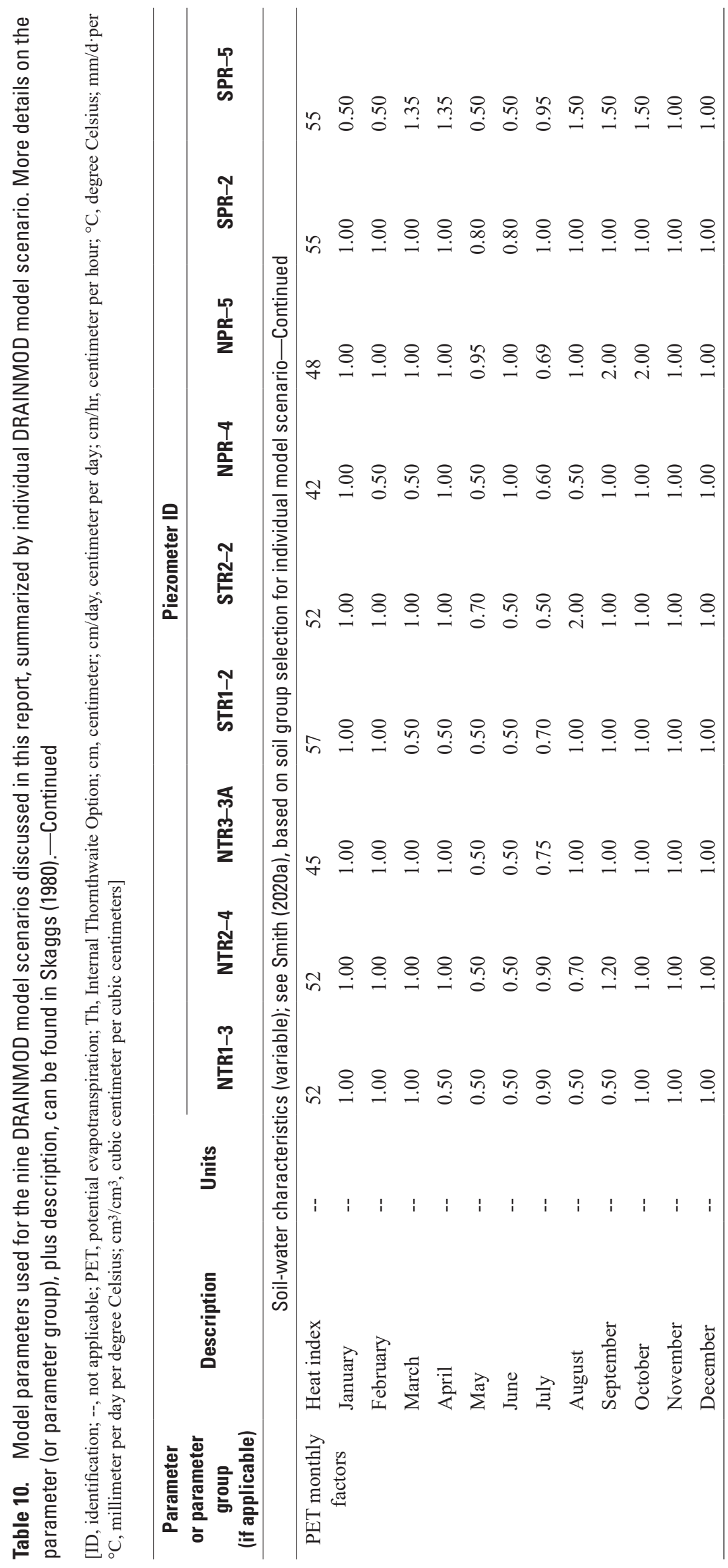


Table 11. Potential recharge rate and two calibration statistics for the nine DRAINMOD model scenarios completed across the study area.

[ID, identification; --, not applicable]

\begin{tabular}{|c|c|c|c|c|}
\hline Piezometer ID & $\begin{array}{l}\text { Potential recharge } \\
\text { (deep seepage), } \\
\text { in inches }\end{array}$ & $\begin{array}{c}\text { Nash-Sutcliffe index of } \\
\text { efficiency }\end{array}$ & $\begin{array}{c}\text { Mean absolute error of } \\
\text { water levels, } \\
\text { in centimeters }\end{array}$ & $\begin{array}{c}\text { Mean absolute error of } \\
\text { water levels } \\
\text { in inches }\end{array}$ \\
\hline \multicolumn{5}{|c|}{ Water years 2017-18 (combined) } \\
\hline NTR1-3 & 2.42 & 0.57 & 10.05 & 3.96 \\
\hline NTR2-4 & 2.07 & 0.60 & 10.90 & 4.29 \\
\hline NTR3-3A & 6.67 & 0.72 & 17.12 & 6.74 \\
\hline NPR-5 & 8.97 & 0.72 & 14.88 & 5.86 \\
\hline STR1-2 & 3.86 & 0.75 & 15.42 & 6.07 \\
\hline STR2-2 & 3.97 & 0.78 & 18.71 & 7.37 \\
\hline SPR-2 & 9.49 & 0.76 & 12.95 & 5.10 \\
\hline
\end{tabular}

model results (table 12). These results were not remarkable, considering the variation that can happen when using multiple recharge estimation techniques and the fundamental differences in the methodology for each method (Healy and Scanlon, 2010). Other studies that included multiple techniques found varying results when using multiple techniques (Healy and Cook, 2002; Delin and others, 2007; Smith and others, 2017). However, all methods did show a fundamental difference between piezometers within the drained area and piezometers outside the drained area, even in cases where the distance to the nondrained piezometer was rather small (figs. 2 and 3). The drained areas had a lower overall potential groundwater recharge compared to the nondrained areas for all three estimates. For RISE WTF, the difference for the 2018 recharge estimates was slightly higher than 1 inch; for the DRAINMOD model, the difference was almost double for the nine sites; and for the SWB model, the difference between the drain and undrained plots was even more substantial.

The results of this study, using three different methods, were different than an Indiana study that determined higher recharge rates with subsurface drainage than without subsurface drainage (Fisher and Healy, 2008). However, the study in this report used three different methods, including the DRAINMOD model, that could specifically account for tile drains. Overall, the lack of agreement between this study and the study in Fisher and Healy (2008) highlights the need for more studies that cover a longer period of time, because this study only lasted 2 years and the Fisher and Healy (2008) only discussed 1 year.

\section{Limitations and Assumptions}

The most important assumption for the study was that the continuous piezometer records were assumed to represent the water-table surface elevations, also known as the potentiometric surfaces. It was also assumed that water-table rises were not caused by atmospheric changes in pressure and represented rises caused by infiltrating water. As mentioned in the "Potential Groundwater Recharge" section, the RISE WTF method and DRAINMOD model do not have a mechanism to distinguish the water-level rise caused by pipe pressurization. Furthermore, the exchange between the locally perched water tables above the restricting layer and the aquifer below the restricting layer was poorly understood. Therefore, potential groundwater recharge was not necessarily at steady state, and it was possible that upward leakage from the aquifer below the restricting layer flowed into areas where the restricting layer was thinner. The upward leakage could have happened if the potentiometric surface of the buried aquifer was above the local water table (same as the water-table surface elevation) because water will flow from higher pressure to lower pressure.

For the two different explicit recharge calculation methods, the RISE WTF model assumed that the specific yield value was 10 percent across all piezometers; however, it is well known that specific yields can vary considerably within a field (Shah and Ross, 2009). Although specific yield could have been calculated from the available VWC data, specific yield is known to vary for one location, a phenomenon that has been described in great detail by several authors (Gillham, 1984; Shah and Ross, 2009). By fixing the specific yield, comparison between the 


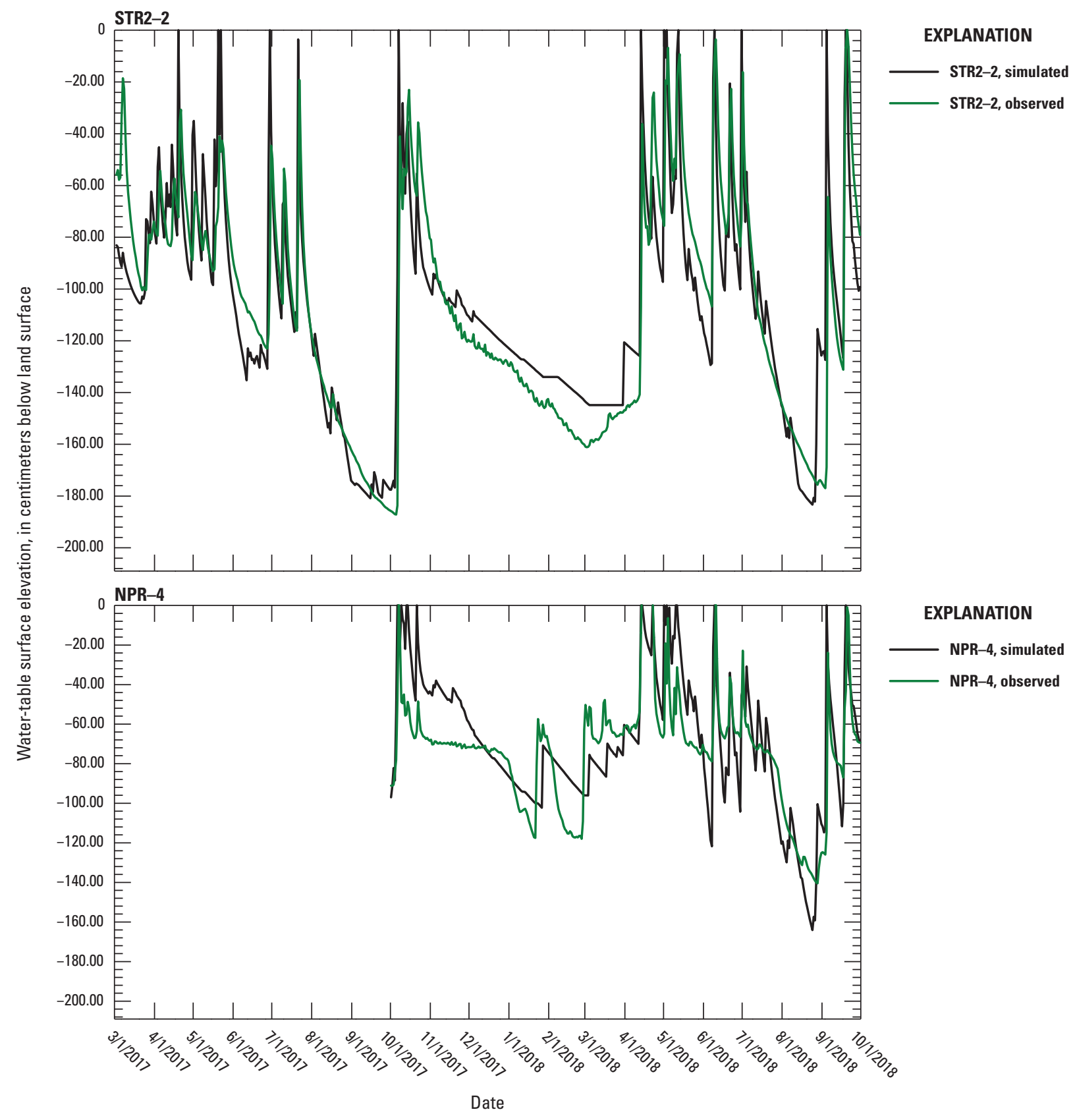

Figure 15. Simulated and observed water-table surface elevation for two of the nine DRAINMOD model scenarios from March 1, 2017, to October 1, 2018: STR2-2 and NPR-4.

different locations was possible. Techniques based on calculating recharge from piezometer hydrographs, such as RISE WTF, are also particularly sensitive to small groundwater rises that are not necessarily caused by a precipitation event (Delin and others, 2007; Healy and Scanlon, 2010). Finally, RISE WTF can also underestimate recharge rates if the water table is close to land surface and recharge happens quickly, because RISE WTF only accounts for the water rise to land surface and does not account for pooled water. For the SWB model, the updated model results were not calibrated, instead relying on the previous calibration (Smith and Westenbroek, 2015).
All ArcGIS applications assumed that the individual coverages were accurate, even though in most cases these coverages are also models. For example, the SSURGO datasets, for which the hydrologic soil groups and soil types were derived, consist of map units that are based on extrapolating soil samples collected over time across the landscape (Natural Resources Conservation Service, 2005). Other datasets included the bedrock topography grid (Jirsa and others, 2011), the NLCD land use and land cover (Homer and others, 2015), the cropland data layers (National Agricultural Statistics Service, 2019), and the USGS DEM (USGS, 2019a). Because the 
Table 12. Annual potential recharge rates based on the DRAINMOD model and RISE Water-Table Fluctuation (WTF) method, grouped by water year. Also shown is the difference between the different methods, in inches per year of recharge.

[ID, identification; WTF, Water-Table Fluctuation; P.R., partial record; --, no record; na, not applicable]

\begin{tabular}{|c|c|c|c|c|c|c|}
\hline \multirow{3}{*}{ Piezometer ID } & \multicolumn{6}{|c|}{ Annual potential recharge rate, in inches per year } \\
\hline & \multicolumn{2}{|c|}{ DRAINMOD } & \multicolumn{2}{|c|}{ RISE WTF } & \multicolumn{2}{|c|}{ Difference (DRAINMOD-RISE WTF) } \\
\hline & $\begin{array}{c}\text { Water year } \\
2017\end{array}$ & $\begin{array}{c}\text { Water year } \\
2018\end{array}$ & $\begin{array}{c}\text { Water year } \\
2017\end{array}$ & $\begin{array}{c}\text { Water year } \\
2018\end{array}$ & $\begin{array}{c}\text { Water year } \\
2017\end{array}$ & Water year 2018 \\
\hline NTR1-3 & 2.43 & 2.41 & 2.26 & 2.68 & 0.18 & -0.26 \\
\hline NTR2-4 & 2.09 & 2.06 & 1.15 & 1.98 & 0.94 & 0.08 \\
\hline NTR3-3A & 6.72 & 6.62 & P.R. & 1.77 & -- & 4.85 \\
\hline NPR-4 & -- & 5.78 & 2.08 & 3.01 & -- & 2.77 \\
\hline NPR-5 & -- & 8.97 & 1.51 & 3.42 & -- & 5.55 \\
\hline STR1-2 & 3.86 & 3.85 & 1.60 & 3.45 & 2.27 & 0.40 \\
\hline STR2-2 & 4.08 & 3.85 & 1.59 & N.R. & 2.50 & -- \\
\hline SPR-2 & -- & 9.49 & P.R. & 1.87 & -- & 7.62 \\
\hline SPR-5 & 4.38 & 4.02 & P.R. & 3.19 & -- & 0.84 \\
\hline Mean difference & na & na & na & na & 1.47 & 2.73 \\
\hline
\end{tabular}

extrapolation of potential areas of southeastern Minnesota was based on these coverages, the final map was only an estimate of the potential areas that could be affected by agricultural drainage.

Finally, the site locations limited comparisons, because the ideal study sites would have compared field sites with the same type of soils on the drained and undrained sites, all sites would have the same crop management from year to year, and all sites would have a shallower depth to bedrock. Instead, the final sites secured had considerable differences between the drained and undrained portions, so comparison between these sites was limited. The study length was also limited because the site agreements could only be secured for a limited period. Ideally, this study would have run for a minimum of 5 years or more to obtain a larger assemblage of potential groundwater recharge rates, but funding limited the length of time to carry out the study.

\section{Summary}

Subsurface drainage is used to efficiently drain saturated soils to support productive agriculture in poorly drained terrains. Periods with water-logged soils are diminished by expediting the movement of water out of the field via buried drains. Subsurface drainage clearly alters the water balance for agricultural fields, but its effect on individual fluxes such as evapotranspiration and groundwater recharge are not well-established. Because its effect on groundwater recharge is poorly understood, the subsurface drainage effect on groundwater resources is also poorly characterized.
In Minnesota, subsurface drainage has historically been implemented in the south-central and western portions of the State, with regions of Minnesota underlain primarily by thick impermeable glacial sediments. Recently, however, subsurface drainage has begun to increase in southeast Minnesota. Unlike historically drained regions of the State, much of southeast Minnesota is underlain by permeable karstic bedrock aquifers, with only a thin layer of glacial sediments separating these aquifers from land surface.

To gain a better understanding of groundwater recharge effects from subsurface drainage, the U.S. Geological Survey (USGS) led a 2-year hydrologic study, in cooperation with the Legislative-Citizen Commission on Minnesota Resources, to investigate this connection for two agricultural fields in southeastern Minnesota with subsurface drainage. A total of three monitoring plots were used between the two agricultural fields: two monitoring plots that included an actively drained area with peripheral, undrained areas, and a third monitoring plot without any subsurface drainage. Multiple piezometer transects were set up across the three monitoring plots to characterize the unsaturated zone and shallow water-table flow using pressure transducers and soil moisture probes. From these piezometers, groundwater recharge rates were derived using two different methods: the RISE Water-Table Fluctuation (WTF) method and the DRAINMOD model. In addition to these two methods, the USGS Soil-Water-Balance (SWB) model was used to estimate potential recharge rates for three different monitoring plots. Subsurface drain flow was continuously monitored with varying success from the two plots with active subsurface drainage. The two drainage monitoring plots were also compared with a third, undrained site. 
In addition to deriving groundwater recharge rates, a hydrologic budget analysis was performed to interpret the water-table surface elevation and soil volumetric water content time series. At one of the two drained plots, the transects exhibited varying water-table surface elevation patterns. Frequent backflow from the adjacent ditch caused subsurface drainage flow to slow down or stop drainage through the main collector drain and cause pipe pressurization, so the closest transect appeared to be mostly controlled by the drain pressurization whereas the farthest transect was more efficiently drained. Both of the drained monitoring plots had an elevation gradient parallel to the pattern tiles, sloping downward towards the collector drain that aggregated the parallel lines into a single drain. Because the transects were set at different gradients in the field, some of the water-table surface elevation differences were also attributed to lateral flow towards the lowest parts of the field.

Three methods were used to derive potential groundwater recharge rates: the RISE WTF method, the USGS SWB model, and DRAINMOD-derived deep seepage rates. Potential groundwater recharge rates, using the RISE WTF method, across all piezometers were 1.55 and 1.94 inches per year, respectively, for water years 2017 and 2018. More differentiation of potential recharge rates between different piezometer types occurred for water year 2018. Although the difference was slightly more than 1 inch between the drained and nondrained piezometers for water year 2018, this difference was statistically significant based on a t-test with a $p$-value of $0.036(\alpha=0.05)$. When looking at recharge based on distance from the drain, the subsurface drain did not affect potential recharge, although other factors such as variability in screen depths, well construction, and specific yield variability cannot be eliminated. The SWB model was also used to estimate potential recharge rates for water years 2017-18, with rates between 2.44 and 5.92 inches per year for the two drained sites, generally higher than the RISE WTF estimates. DRAINMOD-derived potential recharge rates were generally the highest of the three methods, with potential recharge rates varying from 2.07 to 9.49 inches per year.

Overall, there was a lack of agreement between the three methods. These results were not remarkable, considering the fundamental differences in the methodology for each method. Also, other studies that included multiple techniques had varying results when using multiple techniques. However, all methods did show a fundamental difference between piezometers within the drained area and piezometers outside the drained area, including the third undrained monitoring plot. The drained areas had a lower overall potential groundwater recharge compared to the nondrained areas for all three estimates. The difference for the 2018 recharge estimates was slightly higher than 1 inch for the RISE WTF method, the difference was almost double for the nine sites for the DRAINMOD model, and the difference between the drain and undrained plots was even more substantial for the SWB model.

\section{References Cited}

Agricultural Research Service, 1999, Rosetta model: U.S. Department of Agriculture, Agricultural Research Service, accessed on October 10, 2019, at https:/www.ars.usda.gov/ pacific-west-area/riverside-ca/agricultural-water-efficiencyand-salinity-research-unit/docs/model/rosetta-model/.

Agri Drain Corporation, 2019, Inline water level control structures: Agri Drain Corporation, accessed December 26, 2019 , at https:/www.agridrain.com/shop/c85/water-level-controlstructures/p901/inline-water-level-control-structures/.

Alexander, C.A., 1988, ADAPT - A model to simulate pesticide movement into drain tiles: The Ohio State University, Department of Agricultural Engineering, MS Thesis, 241 p. [Also available at https://etd.ohiolink.edu/!etd.send file? accession $=$ osu $1145373108 \&$ disposition=attachment.]

Allen, R.G., Pereira, L.S., Raes, D., and Smith, M., 1998, Crop evapotranspiration-Guidelines for computing crop water requirements: Rome, Food and Agriculture Organization of the United Nations, FAO Irrigation and Drainage Paper 56, 300 p. [Also available at http://www.fao.org/3/X0490E/ X0490E00.htm.]

Allred, B.J., and Redman, J.D., 2010, Location of agricultural drainage pipes and assessment of agricultural drainage pipe conditions using ground penetrating radar: Journal of Geophysics and Engineering, v. 15, no. 3, p. 119-134. [Also available at https://doi.org/10.2113/JEEG15.3.119.]

Beauchamp, K.H., 1987, A history of drainage and drainage methods, in Pavelis, G.A., ed., Farm drainage in the United States-History, status, and prospects: Washington, D.C., U.S. Department of Agriculture Economic Research Service, Miscellaneous Publication Series 186, p. 13-29.

Blann, K.L., Anderson, J.L., Sands, G.R., and Vondracek, B., 2009, Effects of agricultural drainage on aquatic ecosystems - A review: Critical Reviews in Environmental Science and Technology, v. 39, no. 11, p. 909-1001. [Also available at https://doi.org/10.1080/10643380801977966.]

Brye, K.R., Norman, J.M., Bundy, L.G., and Gower, S.T., 2000, Water-budget evaluation of prairie and maize ecosystems: Soil Science Society of America Journal, v. 64, no. 2, p. 715-724. [Also available at https://doi.org/10.2136/ sssaj2000.642715x.]

Capel, P.D., McCarthy, K.A., Coupe, R.H., Grey, K.M., Amenumey, S.E., Baker, N.T., and Johnson, R.L., 2018, Agriculture - A river runs through it - The connections between agriculture and water quality: U.S. Geological Survey Circular 1433, 201 p. [Also available at https://doi.org/10.3133/cir1433.] 
Cowles, D.A., Gabiou, J.F., Harms, G.F., Kubier, J.E., Sickler, G.F., Simpson, G.A., Arneman, H.F., Hanson, I.D., Lamison, L.C., and Whalen, G., 1958, Soil survey of Fillmore County, Minnesota: U.S. Department of Agriculture, Soil Conservation Service Series 1954, no. 1,47 p.

Cunningham, W.L., and Schalk, C.W., comps., 2011, Groundwater technical procedures of the U.S. Geological Survey: U.S. Geological Survey Techniques and Methods, book 1, chap. A1, 151 p. [Also available at https://pubs.usgs.gov/tm/1a1/.]

Decagon Devices, 2016, 5TM-Water content and temperature sensors: Pullman, Wash., Decagon Devices, Inc., 19 p.

Delin, G.N., 1991, Hydrogeology and simulation of groundwater flow in the Rochester area, southeastern Minnesota, 1987-88: U.S. Geological Survey Water-Resources Investigations Report 90-4081, 108 p. [Also available at https://pubs.er.usgs.gov/publication/wri904081.]

Delin, G.N., Healy, R.W., Lorenz, D.L., and Nimmo, J.R., 2007, Comparison of local- to regional-scale estimates of ground-water recharge in Minnesota, USA: Journal of Hydrology, v. 334, no. 1-2, p. 231-249. [Also available at https://dx.doi.org/10.1016/j.jhydrol.2006.10.010.]

Dinnes, D.L., Karlen, D.L., Jaynes, D.B., Kaspar, T.C., Hatfield, J.L., Colvin, T.S., and Cambardella, C.A., 2002, Nitrogen management strategies to reduce nitrate leaching in tile-drained Midwestern soils: Agronomy Journal, v. 94, no. 1, p. 153-171. [Also available at https://doi.org/ 10.2134/agronj2002.1530.]

Fausey, N.R., Doering, E.J., and Palmer, M.L., 1987, Purposes and benefits of drainage, in Pavelis, G.A., ed., Farm drainage in the United States-History, status, and prospects: Washington, D.C., U.S. Department of Agriculture Economic Research Service, Miscellaneous Publication Series 186, p. 48-51.

Fisher, L.H., and Healy, R.W., 2008, Water movement within the unsaturated zone in four agricultural areas of the United States: Journal of Environmental Quality, v. 37, p. 1051-1063. [Also available at https://doi.org/10.2134/ jeq2006.0561.]

Geoprobe Systems, 2019, Set a monitoring well the Geoprobe way: Geoprobe Systems, accessed October 10, 2019, at https:/geoprobe.com/set-monitoring-well-geoprobe-way.

Gillham, R., 1984, The capillary fringe and its effect on watertable response: Journal of Hydrology, v. 67, p. 307-324. [Also available at https://dx.doi.org/10.1016/00221694(84)90248-8.]
Goolsby, D.A., and Battaglin, W.A., 2001, Long-term changes in concentrations and flux of nitrogen in the Mississippi River Basin, USA: Hydrological Processes, v. 15, no. 7, p. 1209-1226. [Also available at https://doi.org/10.1002/ hyp.210.]

Green, C.H., Tomer, M.D., Di Luzio, M., and Arnold, J.G., 2006, Hydrologic evaluation of the Soil and Water Assessment Tool for a large tile-drained watershed in Iowa: Transactions of the ASABE, v. 49, no. 2, p. 413-422. [Also available at https://doi.org/10.13031/2013.20415.]

Green, J.A., Runkel, A.C., and Alexander, E.C., 2012, Karst conduit flow in the Cambrian St. Lawrence Confining Unit, southeast Minnesota, USA: Carbonates and Evaporites, v. 27, no. 2, p. 167-172. [Also available at https://doi.org/ 10.1007/s13146-012-0102-9.]

Groten, J.T., and Alexander, E.C., 2013, Karst hydrogeologic investigation of Trout Brook, Dakota County: Minnesota, University of Minnesota Water Resources Science, 64 p. [Also available at https://conservancy.umn.edu/handle/11299/184787.]

Hanson, M.J., 1987, Damning agricultural drainage - The effect of wetland preservation and federal regulation on agricultural drainage in Minnesota: William Mitchell Law Review, v. 3, no. 1, p. 135-191.

Healy, R.W., and Cook, P.G., 2002, Using groundwater levels to estimate recharge: Hydrogeology Journal, v. 10, no. 1, p. 91-109. [Also available at https://doi.org/10.1007/ s10040-001-0178-0.]

Healy, R.W., Winter, T.C., LaBaugh, J.W., and Franke, O.L., 2007, Water budgets - Foundations for effective waterresources and environmental management: U.S. Geological Survey Circular 1308, 90 p. [Also available at https://pubs.usgs.gov/circ/2007/1308/.]

Healy, R.W., and Scanlon, B.R., 2010, Estimating groundwater recharge: New York, N.Y., Cambridge University Press, 256 p. [Also available at https://doi.org/10.1017/ CBO9780511780745.]

Henine, H., Nédélec, Y., Augeard, B., Birgand, F., Chaumont, C., Ribstein, P., and Kao, C., 2010, Effect of pipe pressurization on the discharge of a tile drainage system: Vadose Zone Journal, v. 9, no. 1, p. 36-42. [Also available at https://doi.org/10.2136/vzj2008.0152.]

Hobbs, H.C., and Goebel, J.E., 1982, Geologic map of Minnesota, Quaternary geology: Minnesota Geological Survey S-01, 1 plate. [Also available at https://conservancy.umn.edu/handle/11299/60085.] 
Hobbs, H.C., 1998, Use of 1-2-millimeter sand-grain composition in Minnesota Quaternary studies, in Patterson, C.J., and Wright, H.E., Jr., eds., Contributions to Quaternary studies in Minnesota, Report of Investigations 49: Minnesota Geological Survey, p. 193-208.

Homer, C.G., Dewitz, J.A., Yang, L., Jin, S., Danielson, P., Xian, G., Coulston, J., Herold, N.D., Wickham, J.D., and Megown, K., 2015, Completion of the 2011 National Land Cover Database for the conterminous United StatesRepresenting a decade of land cover change information: Photogrammetric Engineering and Remote Sensing, v. 81, p. 345-354.

Hooghoudt, S.B., 1952, Tile drainage and subirrigation: Soil Science, v. 74, no. 1, p. 35-48. [Also available at https://doi.org/10.1097/00010694-195207000-00005.]

Jin, C., Sands, G., and Hansen, B., 2004, Observed and simulated water table depths in subsurface drained soils in northwest Minnesota, in Proceedings of the Eighth International Symposium, March 21-24, Sacramento, CA: American Society of Agricultural and Biological Engineers, p. 228-240.

Jirsa, M.A., Boerboom, T.J., Chandler, V.W., Mossler, J.H., Runkel, A.C., and Setterholm, D.R., 2011, S-21 Geologic map of Minnesota-Bedrock geology: Minnesota Geological Survey, 1 plate. [Also available at https://conservancy.umn.edu/handle/11299/101466.]

Johnson, A.I., 1967, Specific yield-Compilation of specific yields for various materials: U.S. Geological Survey Water Supply Paper 1662-D, 74 p. [Also available at https://pubs.er.usgs.gov/publication/wsp1662D.]

Johnson, M.D., Adams, R.S., Gowan, A.S., Harris, K.L., Hobbs, H.C., Jennings, C.E., Knaeble, A.R., Lusardi, B.A., and Meyer, G.N., 2016, Quaternary lithostratigraphic units of Minnesota: Minnesota Geological Survey Report of Investigations 68, $262 \mathrm{p}$.

Kanwar, R.S., Baker, J.L., and Mukhtar, S., 1998, Excessive soil water effects at various stages of development on the growth and yield of corn: Transactions of the ASAE, v. 31, p. 133-141. [Also available at https://doi.org/10.13031/ 2013.30678.]

Keeler, B.L., and Polasky, S., 2014, Land-use change and costs to rural households - A case study in groundwater nitrate contamination: Environmental Research Letters, v. 9, no. 7, p. 074002. [Also available at https://doi.org/10.1088/ 1748-9326/9/7/074002.]

Khand, K., Kjaersgaard, J., Hay, C., and Jia, X., 2017, Estimating impacts of agricultural subsurface drainage on evapotranspiration using the landsat imagery-based METRIC model: Hydrology, v. 4, 16 p.
Kladivko, E.J., Frankenberger, J.R., Jaynes, D.B., Meek, D.W., Jenkinson, B.J., and Fausey, N.R., 2004, Nitrate leaching to subsurface drains as affected by drain spacing: Journal of Environmental Quality, v. 33, no. 5, p. 1803-1813. [Also available at https://doi.org/10.2134/jeq2004.1803.]

Legates, D.R., and McCabe, G.J., Jr., 1999, Evaluating the use of "goodness-of-fit" measures in hydrologic and hydroclimatic model validation: Water Resources Research, v. 35, no. 1, p. 233-241. [Also available at https://doi.org/10.1029/ 1998WR900018.]

Lindgren, R.J., 2001, Ground-water recharge and flowpaths near the edge of the Decorah-Platteville-Glenwood confining unit, Rochester, Minnesota: U.S. Geological Survey Water-Resources Investigations Report 00-4215, 46 p. [Also available at https://pubs.er.usgs.gov/publication/wri20004215.]

Lorenz, D.L., and Delin, G.N., 2007, A regression model to estimate regional ground water recharge: Ground Water, v. 45, no. 2, p. 196-208. [Also available at https://doi.org/ 10.1111/j.1745-6584.2006.00273.x.]

Lorenz, D.L., 2016, DVstats-Functions for manipulating daily values, R package version 0.3.3: U.S. Geological Survey, accessed September 30, 2016, at https://github.com/ USGS-R/DVstats.

McDonald, J.E., 1961, On the ratio of evaporation to precipitation: Bulletin of the American Meteorological Society, v. 42, no. 3, p. 185-189. [Also available at https://doi.org/ 10.1175/1520-0477-42.3.185.]

Meyer, G.N., 2000, Quaternary geology of Mower County, in Mossler, J.H., Contributions to the geology of Mower County, Minnesota: Minnesota Geological Survey Report of Investigations, v. 50, p. 31-61.

Minnesota Department of Health, 2011, A guide to the rules relating to wells and borings: Minnesota Department of Health, Minnesota Rules, chapter 4725, 602 p. [Also available at

https://www.health.state.mn.us/communities/environment/ water/docs/wells/ruleshandbook.pdf.]

Minnesota Geospatial Information Office, 2008, LiDAR Elevation, Southeast Minnesota, 2008: Minnesota Geospatial Commons, digital data, accessed December 30, 2019, at https://gisdata.mn.gov/dataset/elev-lidar-semn2008

Moebius-Clune, B.N., Moebius-Clune, D.J., Gugino, B.K., Idowu, O.J., Schindelbeck, R.R., Ristow, A.J., van Es, H.M., Thies, J.E., Shayler, H.A., McBride, M.B., Wolfe, D.W., and Abawi, G.S., 2017, Comprehensive assessment of soil health-The Cornell Framework, Edition 3.2: Cornell University, $123 \mathrm{p}$. 
Mossler, J.H., 1995, Geologic atlas of Fillmore County, Minnesota [Parts A and C]: Minnesota Geological Survey C-08, 5 plates. [Also available at https://conservancy.umn.edu/handle/11299/58513.]

Muñoz-Carpena, R., 2004, Field devices for monitoring soil water content: Florida Cooperative Extension Service Bulletin 343, 15 p. [Also available at https://edis.ifas.ufl.edu/ae266.]

Nash, J.E., and Sutcliffe, I.V., 1970, River flow forecasting through conceptual models part 1-A discussion of principles: Journal of Hydrology, v. 10, no. 3, p. 282-290. [Also available at https://doi.org/10.1016/0022-1694(70)90255-6.]

National Agricultural Statistics Service [NASS], 2019, 2017 Minnesota cropland data layer: U.S. Department of Agriculture, National Agricultural Statistics Service, accessed October 10, 2019, at https://www.nass.usda.gov/ Research_and_Science/Cropland/Release/.

National Climatic Data Center, 2019, Climate data online: National Oceanic and Atmospheric Administration, National Centers for Environmental Information, digital data, accessed April 25, 2019, at https://www.ncdc.noaa.gov/ cdo-web/.

Natural Resources Conservation Service, 2005, Soil survey geographic (SSURGO) data base-Data use information: Fort Worth, Texas, U.S. Department of Agriculture, Natural Resources Conservation Service, Miscellaneous Publication Number 1527, $110 \mathrm{p}$.

Natural Resources Conservation Service, 2019, SSURGO web soil survey, United States of Agriculture, Soil Survey Staff, accessed on October 10, 2019, at https://websoilsurvey.sc.egov.usda.gov/App/ WebSoilSurvey.aspx.

Naz, B.S., Ale, S., and Bowling, L.C., 2009, Detecting subsurface drainage systems and estimating drain spacing in intensively managed agricultural landscapes: Agricultural Water Management, v. 96, no. 4, p. 627-637. [Also available at https://doi.org/10.1016/j.agwat.2008.10.002.]

North Carolina State University, 2019, DRAINMOD-A computer simulation model: North Carolina State University Agricultural Water Management, accessed October 10, 2019, at https://www.bae.ncsu.edu/agricultural-watermanagement/drainmod/.

Onset Computer Corporation, 2016, HOBO U30-NRC user's guide: Bourne, Mass., Onset Computer Corporation, 54 p.

OTT Hydromet, 2019, OTT Orpheus mini water level logger: OTT Hydromet, accessed October 10, 2019, at https://www.ott.com/products/water-level-1/ott-orpheusmini-water-level-logger-3/.
Randall, G.W., and Mulla, D.J., 2001, Nitrate nitrogen in surface waters as influenced by climatic conditions and agricultural practices: Journal of Environmental Quality, v. 30, no. 2, p. 337-344. [Also available at https://doi.org/ 10.2134/jeq2001.302337x.]

Rawls, W.J., Brakensiek, D.L., and Miller, N., 1983, GreenAmpt infiltration parameters from soils data: Journal of Hydraulic Engineering, v. 109, no. 1, p. 62-70. [Also available at https://doi.org/10.1061/(ASCE)07339429(1983)109:1(62).]

Reeve, R.C., Slicker, R.E., and Lang, T.J., 1981, Corrugated plastic tubing, in Proceedings of the American Society of Civil Engineers, International Conference on Underground Plastic Pipe, p. 227-242.

Richards, R.P., Bouchard, V., and McCall, R., 2008, Water quality in drainage ditches influenced by agricultural subsurface drainage: The Ohio State University Extension Fact Sheet, WS-3857-08, 5 p.

Rijal, I., Jia, X., Zhang, X., Steele, D.D., Scherer, T.F., and Akyuz, A., 2012, Effects of subsurface drainage on evapotranspiration for corn and soybean crops in southeastern North Dakota: Journal of Irrigation and Drainage Engineering, v. 138, no. 12, p. 1060-1067. [Also available at https://doi.org/10.1061/(ASCE)IR.1943-4774.0000508.]

Roth, J.L., and Capel, P.D., 2012, The hydrology of a drained topographical depression within an agricultural field in North-Central Iowa: Transactions of the ASABE, v. 55, no. 5, p. 1801-1814. [Also available at https://doi.org/ 10.13031/2013.42367.]

Rozemeijer, J.C., Van Der Velde, Y., Van Geer, F.C., Bierkens, M.F.P., and Broers, H.P., 2010, Direct measurements of the tile drain and groundwater flow route contributions to surface water contamination-From field-scale concentration patterns in groundwater to catchment-scale surface water quality: Environmental Pollution, v. 158, no. 12, p. 3571-3579. [Also available at https://doi.org/10.1016/ j.envpol.2010.08.014.]

RStudio Team, 2019, RStudio-Integrated development for R: Boston, Mass., RStudio, Inc., accessed July 3, 2019, at https://www.rstudio.com/.

Runkel, A.C., Tipping, R.G., Alexander, E.C., Jr., Green, J.A., Mossler, J.H., and Alexander, S.C., 2003, Hydrogeology of the Paleozoic bedrock in southeastern Minnesota: Minnesota Geological Survey Report of Investigations 61, 105 p., 2 plates. [Also available at https://conservancy.umn.edu/handle/11299/58813.] 
Rutledge, A.T., 1997, Model-estimated ground-water recharge and hydrograph of ground-water discharge to a stream: U.S. Geological Survey Water-Resources Investigations Report 97-4253, 29 p. [Also available at https://pubs.usgs.gov/wri/wri974253/.]

Rydlund, P.H., and Densmore, B.K., 2012, Methods of practice and guidelines for using survey-grade global navigation satellite systems (GNSS) to establish vertical datum in the United States Geological Survey: U.S. Geological Survey Techniques and Methods, book 11, chap. D1, 102 p. with appendixes. [Also available at https://pubs.er.usgs.gov/ publication/tm11D1.]

Schottler, S.P., Ulrich, J., Belmont, P., Moore, R., Lauer, J.W., Engstrom, D.R., and Almendinger, J.E., 2013, Twentieth century agricultural drainage creates more erosive rivers: Hydrological Processes, v. 28, no. 4, p. 1951-1961. [Also available at https://doi.org/10.1002/hyp.9738.]

Schuh, W.M., 2008, Potential effects of subsurface drainage on water appropriation and the beneficial use of water in North Dakota: North Dakota State Water Commission, Water Resources Investigation No. 45, 110 p.

Schuh, W.M., 2018, Potential effects of subsurface drainage on water appropriation and the beneficial use of water in North Dakota-Addendum - Special cases: North Dakota State Water Commission, Water Resources Investigation No. $45 \mathrm{~A}, 35 \mathrm{p}$.

Shah, N., and Ross, M., 2009, Variability in specific yield under shallow water table conditions: Journal of Hydrologic Engineering, v. 14, no. 12, p. 1290-1298. [Also available at https://doi.org/10.1061/(ASCE)HE.1943-5584.0000121.]

Skaggs, R.W., 1980, Drainmod reference report—Methods for design and evaluation of drainage-water management systems for soils with high water tables. U.S. Department of Agriculture, Soil Conservation Service, $332 \mathrm{p}$.

Skaggs, R.W., Youssef, M.A., and Chescheir, G.M., 2012, Drainmod-Model use, calibration, and validation: Transactions of the ASABE, v. 55, no. 4, p. 1509-1522. [Also available at https://doi.org/10.13031/2013.42259.]

Smith, E.A., 2012, Spatial and temporal variability of preferential flow in a subsurface-drained landscape in northcentral Iowa: University of Minnesota, Water Resources Science Ph.D. Dissertation, 254 p., with appendices. [Also available at https://conservancy.umn.edu/handle/ 11299/122877.]

Smith, E.A., 2020a, DRAINMOD simulations for two agricultural drainage sites in western Fillmore County, southeastern Minnesota: U.S. Geological Survey data release, https://doi.org/10.5066/P987N30U.
Smith, E.A., 2020b, Soil-Water Balance model datasets used to estimate recharge for southeastern Minnesota, 2014-2018: U.S. Geological Survey data release, https://doi.org/10.5066/P90N4AWG.

Smith, E.A., 2020c, Potential groundwater recharge estimates based on a groundwater rise analysis technique for two agricultural sites in southeastern Minnesota, 2016-2018: U.S. Geological Survey data release, https://doi.org/10.5066/ P94LMOPP.

Smith, E.A., and Westenbroek, S.M., 2015, Potential groundwater recharge for the State of Minnesota using the SoilWater-Balance model, 1996-2010: U.S. Geological Survey Scientific Investigations Report 2015-5038, 85 p. [Also available at https://doi.org/10.3133/sir20155038.]

Smith, E.A., Lorenz, D.L., Kessler, E.W., Berg, A.M., and Sanocki, C.A., 2017, Groundwater discharge to the Mississippi River and groundwater balances for the Interstate 94 Corridor Surficial Aquifer, Clearwater to Elk River, Minnesota: U.S. Geological Survey Scientific Investigations Report 2017-5114, 68 p. [Also available at https://pubs.er.usgs.gov/publication/sir20175114.]

Smith, E.A., and Capel, P.D., 2018, Specific conductance as a tracer of preferential flow in a subsurface-drained field: Vadose Zone Journal, v. 17, 13 p.

Smith, E., Gillette, T., Blann, K., Coburn, M., Hoppie, B., and Rhees, S., 2018a, Drain tiles and groundwater resourcesUnderstanding the relations. Minnesota Ground Water Association, $68 \mathrm{p}$. [Also available at https://pubs.er.usgs.gov/publication/70204196.]

Smith, E.A., Kiesling, R.L., Ziegeweid, J.R., Elliott, S.M., and Magdalene, S., 2018b, Simulation of hydrodynamics, water quality, and lake sturgeon habitat volumes in Lake St. Croix, Wisconsin and Minnesota, 2013: U.S. Geological Survey Scientific Investigations Report 2017-5157, 60 p. [Also available at https://doi.org/10.3133/sir20175157.]

Solinst, 2014, Solinst Levelogger user guide: Solinst Canada, Ltd., Halton Hills, Ontario, Canada, 82 p.

St. Ores, J., Alexander, E.C., and Halsey, C.F., 1982, Groundwater pollution prevention in southeast Minnesota's karst region: University of Minnesota Agricultural Extension Service 465-1982, 19 p.

Thornthwaite, C.W., 1948, An approach towards a rational classification of climate: Geographical Review, v. 38 , no. 1, p. 55-94. [Also available at https://doi.org/ 10.2307/210739.]

Thornthwaite, C.W., and Mather, J.R., 1957, Instructions and tables for computing potential evapotranspiration and the water balance: Centerton, N.J., Laboratory of Climatology, Publications in Climatology, v. 10, no. 3, p. 185-311. 
Thornton, P.E., Thornton, M.M., Mayer, B.W., Wei, Y., Devarakonda, R., Vose, R.S., and Cook, R.B., 2018, Daymet - Daily surface weather data on a 1-km grid for North America, Version 3: Oak Ridge, Tenn., ORNL DAAC, accessed October 10, 2019, at https://doi.org/ https://doi.org/10.3334/ORNLDAAC/1328.

Tipping, R.G., Runkel, A.C., Alexander, E.C., Jr., Alexander, S.C., and Green, J.A., 2006, Evidence for hydraulic heterogeneity and anisotropy in the mostly carbonate Prairie du Chien Group, southeastern Minnesota, USA: Sedimentary Geology, v. 184, no. 3-4, p. 305-330. [Also available at https://doi.org/10.1016/j.sedgeo.2005.11.007.]

Trost, J.J., Roth, J.L., Westenbroek, S.M., and Reeves, H.W., 2018, Simulation of potential groundwater recharge for the glacial aquifer system east of the Rocky Mountains, 1980-2011, using the Soil-Water-Balance model: U.S. Geological Survey Scientific Investigations Report 2018-5080, 51 p. [Also available at https://doi.org/10.3133/ sir20185080.]

U.S. Department of Agriculture, 1995, Water Erosion Prediction Project (WEPP) hillslope profile and watershed model documentation: Agricultural Research Service, NSERL Report 10, accessed October 10, 2019, at https:/www.ars.usda.gov/midwest-area/west-lafayette-in/ national-soil-erosion-research/docs/wepp/wepp-modeldocumentation/.

U.S. Department of Agriculture, 1999, Soil taxonomy: A basic system of soil classification for making and interpreting soil surveys: U.S. Department of Agriculture Natural Resources Natural Resources Conservation Service, Agriculture Handbook, Number 436, accessed January 24, 2020, at https://www.nrcs.usda.gov/wps/portal/nrcs/main/soils/ survey/class/taxonomy/.

U.S. Geological Survey [USGS], 2019a, National Elevation Dataset: U.S. Geological Survey, The National Map, accessed October 10, 2019, at https://nationalmap.gov/ elevation.html.

U.S. Geological Survey [USGS], 2019b, USGS groundwater data for Minnesota in USGS water data for the Nation: U.S. Geological Survey National Water Information System database, accessed October 10, 2019, at https://doi.org/10.5066/F7P55KJN.

van Genuchten, M.T., 1980, A closed-form equation for predicting the hydraulic conductivity of unsaturated soils: Soil Science Society of America Journal, v. 44, no. 5, p. 892-898. [Also available at https://doi.org/10.2136/ sssaj1980.03615995004400050002x.]
Westenbroek, S.M., Kelson, V.A., Dripps, W.R., Hunt, R.J., and Bradbury, K.R., 2010, SWB-A modified Thornthwaite-Mather Soil-Water-Balance code for estimating groundwater recharge: U.S. Geological Survey Techniques and Methods, book 6, chap. A31, 60 p. [Also available at https://pubs.usgs.gov/tm/tm6-a31/.]

Westenbroek, S.M., Engott, J.A., Kelson, V.A., and Hunt, R.J., 2018, SWB Version 2.0-A soil-water-balance code for estimating net infiltration and other water-budget components: U.S. Geological Survey Techniques and Methods, book 6, chap. A59, 118 p. [Also available at https://doi.org/ 10.3133/tm6A59.]

Williams, M.A., and Vondracek, B., 2010, distributions and relationships with land cover and hydrogeologic strata in a karst landscape in Winona County, Minnesota, USA: Carbonates and Evaporites, v. 25, no. 4, p. 333-347. [Also available at https://doi.org/10.1007/s13146-010-0037-y.]

Wilson, B., 2016, History of drainage in the northern Midwestern U.S., in Proceedings of the Tenth International Drainage Symposium, September 7-9, Minneapolis, MN: American Society of Agricultural and Biological Engineers, 398 p.

Wright, H.E., Jr., 1972, Quaternary history of Minnesota, in Sims, P.K., and Morey, G.B., eds., Geology of Minnesota-A centennial volume: Minnesota Geological Survey, p. 515-546.

Yang, Y., Anderson, M., Gao, F., Hain, C., Kustas, W., Meyers, T., Crow, W., Finocchiaro, R., Otkin, J., Sun, L., and Yang, Y., 2017, Impact of tile drainage on evapotranspiration in South Dakota, USA, based on high spatiotemporal resolution evapotranspiration time series from a multisatellite data fusion system: IEEE Journal of Selected Topics in Applied Earth Observations and Remote Sensing, v. 10, no. 6, p. 2550-2564. [Also available at https://doi.org/10.1109/ JSTARS.2017.2680411.]

Zucker, L.A., and Brown, L.C., 1998. Agricultural drainageWater quality impacts and subsurface drainage studies in the Midwest: Ohio State University Extension Bulletin 871,40 p. 


\section{Appendix 1. Instantaneous Subsurface Drainage Flow Rates, Every}

15 Minutes, 2017-18

Instantaneous subsurface drainage flow rates for North Site Agri Drain (NSAD) and South Site Agri Drain (SSAD) are presented in table 1.1 and table 1.2, respectively. All

subsurface drainage flow rates based on converting water-level height, collected every 15 minutes, into subsurface drainage flow in cubic feet per second using equations 5 and 6 in the main report. All rates also shown in cubic meters per second. 


\section{Appendix 2. Daily Total Subsurface Drainage, 2017-18}

Total subsurface drain flow per day for North Site Agri Drain (NSAD) and South Site Agri Drain (SSAD) are presented in table 2.1 and table 2.2 , respectively. Total subsurface drainage flow rates shown in cubic feet per day and cubic meters per day. 



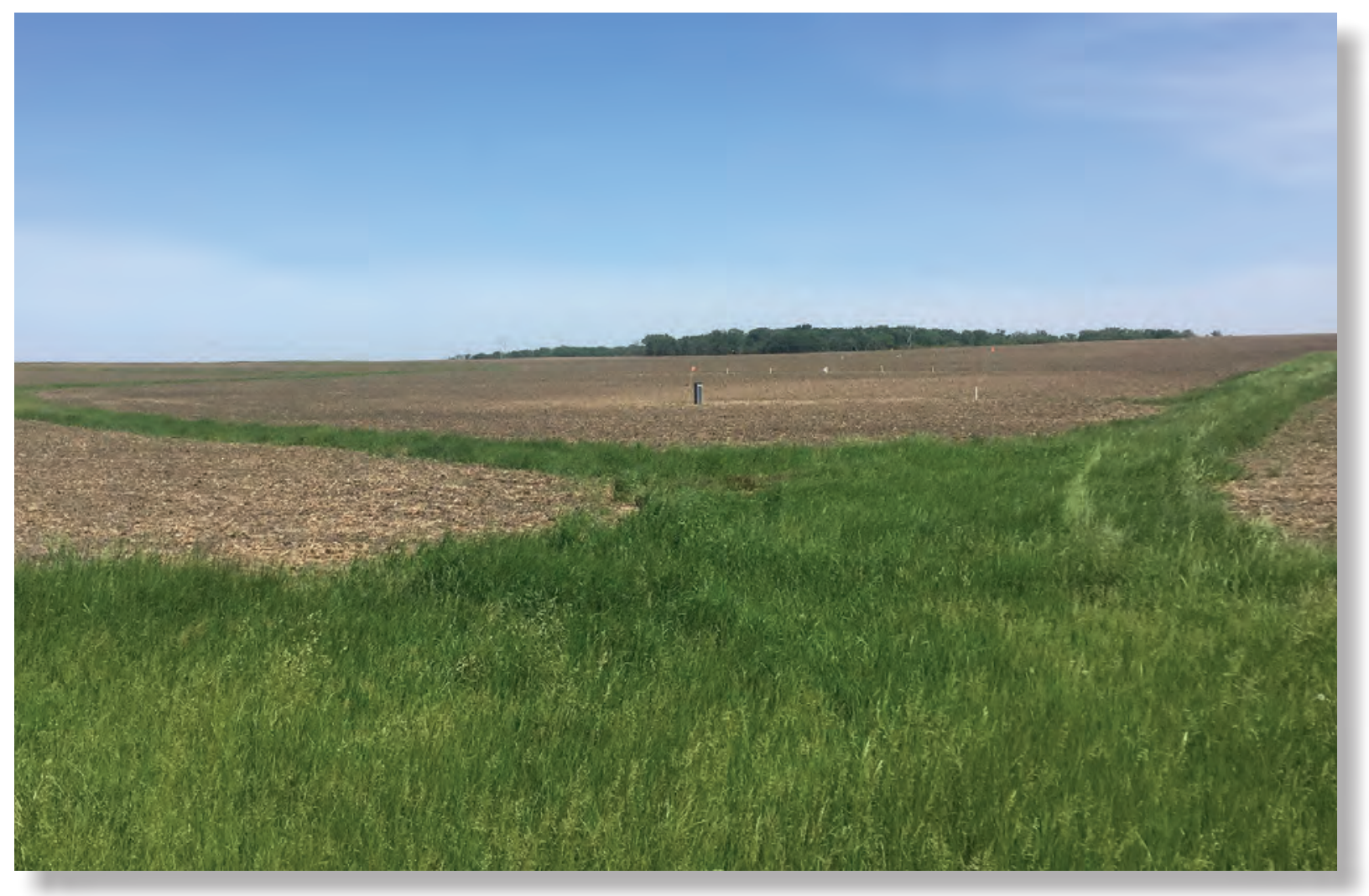

